\author{
UNIVERSIDADE DE SÃO PAULO \\ FACULDADE DE ODONTOLOGIA DE RIBEIRÃO PRETO
}

\title{
Solução efervescente para higiene de próteses totais: Influência na sorção de água, solubilidade, dureza e na alteração de cor de reembasadores.
}

\section{ANTÔNIO DE LUNA MALHEIROS SEGUNDO}

Ribeirão Preto 


\section{ANTÔNIO DE LUNA MALHEIROS SEGUNDO}

\section{Solução efervescente para higiene de próteses totais: Influência na sorção de água, solubilidade, dureza e na alteração de cor de reembasadores.}

Dissertação de mestrado apresentada à Faculdade de Odontologia de Ribeirão Preto da Universidade de São Paulo para obtenção do Título de Mestre em Reabilitação Oral, desenvolvida junto ao Departamento de Materiais Dentários e Prótese.

Orientadora: Prof ${ }^{a}$ Dra Cláudia Helena Lovato da Silva

Ribeirão Preto 
Autorizo a reprodução ou divulgação total ou parcial deste trabalho, por qualquer meio convencional ou eletrônico, para fins de estudo e pesquisa, desde que citada a fonte.

Ficha catalográfica elaborada pela Biblioteca Central do Campus USP - Ribeirão Preto

Malheiros-Segundo, Antônio de Luna

Solução efervescente para higiene de próteses totais: Influência na sorção de água, solubilidade, dureza e na alteração de cor de reembasadores. Ribeirão Preto, 2007

101 p.: 8 il.; $30 \mathrm{~cm}$

Dissertação de Mestrado, apresentada à Faculdade de Odontologia de Ribeirão Preto/ USP;

Área: Reabilitação Oral.

Orientador: Silva-Lovato, Cláudia Helena

1. Prótese Total. 2. Reembasadores. 3. Higienização. 4. Propriedades físicas 


\section{ANTÔNIO DE LUNA MALHEIROS SEGUNDO}

Solução efervescente para higiene de próteses totais: Influência na sorção de água, solubilidade, dureza e na alteração de cor de reembasadores.

Dissertação de mestrado apresentada à Faculdade de Odontologia de Ribeirão Preto da Universidade de São Paulo para obtenção do Título de Mestre em Reabilitação Oral, desenvolvida junto ao Departamento de Materiais Dentários e Prótese.

Ribeirão Preto

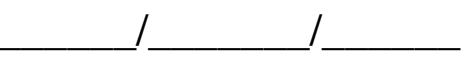

Prof $^{a}$ Dr $^{\mathrm{a}}$ Cláudia Helena Lovato da Silva

Professora Doutora do Departamento de Materiais Dentários e Prótese da Faculdade de Odontologia de Ribeirão Preto - USP

\section{Prof. Dr. João Neudenir Arioli}

Professor Adjunto do Departamento de Materiais Odontológicos e Prótese da Faculdade de Odontologia de Araraquara - UNESP

\section{Prof $^{\mathrm{a}}$ Dr $^{\mathrm{a}}$ Helena de Freitas Oliveira Paranhos}

Professora Associada do Departamento de Materiais Dentários e Prótese da Faculdade de Odontologia de Ribeirão Preto - USP 
Aos meus pais, Antônio e Regina, por serem minha fonte de inspiração e pela sua demonstração de amor à vida e à família. Agradeço pela minha formação profissional e pessoal e aos valores que me foram passados: humildade, sinceridade e educação. Não posso deixar de citar o apoio incondicional às minhas decisões.

Ao meu irmão Felipe, que além de irmão é um amigo que sei que posso contar e confiar para qualquer coisa. Além de lhe agradecer pela amizade, torço para que você consiga alcançar seus desejos pessoais do mesmo modo que vem alcançando os profissionais, com muito sucesso.

À minha namorada Flávia pelo amor e companheirismo. Por sempre estar ao meu lado em todos os momentos. Uma pessoa inigualável que às vezes esquece seus próprios interesses para ajudar. Além de tudo possui uma família maravilhosa, que sempre me fez sentir em casa, me acolhendo como parte dela. 
Aos meus amigos de infância Danilo, Rafael e Vinícius. Amizade como a nossa é algo difícil de encontrar nos dias de hoje. Mesmo com a distância sempre damos um jeito de nos encontrar para relembrar os bons tempos. É muito bom quando cada um de nós conquista suas vitórias, tanto no lado pessoal quanto no lado profissional, pois parece que é a vitória de todos.

Aos meus amigos da gloriosa República 22C e seus agregados. Vocês foram a minha família em Ribeirão Preto.

Aos meus amigos da Pós Graduação. Que em tão pouco tempo se tornaram pessoas imprescindíveis em minha vida. 
Aos funcionários do Departamento de Materiais Dentários e Prótese sempre dispostos a ajudar.

Aos professores do curso de Pós-Graduação em Reabilitação Oral pelos ensinamentos, auxílios e que de alguma forma me ajudaram no crescimento profissional e na busca pelo conhecimento.

À CAPES pelo auxílio na bolsa de estudos que foi de fundamental importância para a realização deste projeto.

À Comissão de Pós-Graduação da FORP-USP pela oportunidade.

Ao Prof. Dr. Osvaldo Luiz Bezzon pela orientação na clínica de Pós-Graduação. 
À minha orientadora, a Profa. Dra. Cláudia Helena Lovato da Silva.

Iniciamos esta jornada na Iniciação Científica em 2003. Desde o início a Profa. Cláudia mostrou a sua vontade de ensinar diferenciada. Qualquer dúvida que eu tinha virava uma solução. Para alguma dificuldade sempre havia uma saída. E os trabalhos foram dando certo e a parceria continuou no programa de Mestrado em Reabilitação Oral. Foram muitas as dificuldades mas com a sua ajuda, professora, tudo ficou mais fácil. Sua paciência com meu jeito de ser e o apoio em todos os momentos, inclusive nos mais difíceis, foi algo primordial para tudo dar certo. Eu não poderia ter tido mais sorte. Muito obrigado por tudo, de coração 


\section{RESUMO}

MALHEIROS-SEGUNDO, A.L. Solução efervescente para higiene de próteses totais: Influência na sorção de água, solubilidade, dureza e na alteração de cor de reembasadores. 2007. 101 p. Dissertação (Mestrado) - Faculdade de Odontologia de Ribeirão Preto, Universidade de São Paulo, Ribeirão Preto, 2007.

Este estudo avaliou propriedades físicas de materiais reembasadores para dentaduras após imersão em solução à base de perborato de sódio. Em todos os testes, os materiais, Kooliner e Elite Soft foram divididos nos grupos G1 (controle): imersão em saliva artificial a $37^{\circ} \mathrm{C}$ e G2 (experimental): imersões diárias em solução à base de perborato de sódio (Corega Tabs) por 5 minutos. Para os testes de sorção, solubilidade, alteração de cor e de dureza, foram obtidos 30 espécimes em forma de disco $(15 \mathrm{x} 3 \mathrm{~mm})$ de cada material, por meio da técnica direta, a partir da prensagem do material em matriz metálica vazada entre duas placas de vidro. A sorção e solubilidade foram avaliadas após 120 dias de imersão. A alteração de cor foi avaliada imediatamente após o acabamento dos corpos-de-prova e após 30 e 120 dias. A dureza dos materiais foi mensurada inicialmente, após 30 e 60 dias de imersão. O teste de Kruskal-Wallis $(\mathrm{P}<0,05)$ indicou que para o material Kooliner, o tipo de imersão $(\mathrm{G} 1=1,43$; G2=1,63) não interferiu nos valores de sorção. Quanto ao Elite soft, o perborato de sódio $(\mathrm{G} 1=0,29 ; \mathrm{G} 2=0,51)$ promoveu aumento significativo nos valores de sorção. Comparando os materiais, o Kooliner apresentou médias de sorção significativamente mais altas que o Elite soft, para os dois grupos estudados. Para solubilidade, o teste Anova $(\mathrm{P}<0,05)$ a dois fatores de variação indicou diferença significante entre o fator grupo e entre o fator material. $O$ Kooliner $(0,168)$ bem como o grupo $1(0,137)$ apresentaram as maiores médias de solubilidade em relação ao Elite soft $(0,089)$ e o grupo 2 , respectivamente. Com relação à cor (Anova, $\mathrm{P}<0,05$ ), os dois materiais sofreram alteração no intervalo de 30 (Kooliner: $\mathrm{G} 1=3,63$, G2=2,87; Elite soft: G1=6,27, G2=6,01) e 120 (Kooliner: G1=4,21, G2=3,94; Elite soft: $\mathrm{G} 1=8,54, \mathrm{G} 2=9,23)$ dias de imersão. O fator grupo não influenciou nesta propriedade dos materiais. Para a dureza do Kooliner, foi aplicada a análise de variância a dois fatores de variação (grupo: $\mathrm{G} 1=6,63$; $\mathrm{G} 2=7,27$ e tempo: T0=5,24; T30=7,28; T60=8,34), que indicou diferença somente para o fator tempo. Após a comparação das médias (Tukey=0,87), notou-se aumento significante $(\mathrm{P}<0,05)$ da dureza entre todos os tempos avaliados. Os corpos-de-prova de Elite soft do grupo experimental $(49,18)$ apresentaram um aumento $(\mathrm{P}<0,05)$ na dureza quando comparado ao grupo controle $(48,72)$. Para o fator tempo, o teste de Tukey $(0,76)$, indicou diferença significante $(\mathrm{P}<0,05)$ entre as três médias $(\mathrm{T} 0=46,45 ; \mathrm{T} 30=49,63$; $\mathrm{T} 60=50,74)$. O perborato de sódio não influenciou de forma significante nas propriedades avaliadas neste estudo. Dentre os materiais, o Kooliner foi o que apresentou maior estabilidade, porém é um material com características diferentes do Elite soft. O tempo é um fator importantíssimo na alteração das propriedades dos materiais, tendo interferido em todas as variáveis testadas. Estudos com o objetivo de aprimorar as características dos materiais para uma aplicação a longo prazo devem ser ainda realizados, visando a viabilidade de uso dos materiais reembasadores.

Descritores: Prótese Total, Reembasadores, Higienização, Propriedades Físicas. 


\begin{abstract}
MALHEIROS-SEGUNDO, A.L. Solution effervescent for denture hygiene: Influence in the water sorption, solubility, hardness and color alterations of denture liners. 2007. 101p. Dissertação (Mestrado) - Faculdade de Odontologia de Ribeirão Preto, Universidade de São Paulo, Ribeirão Preto, 2007.
\end{abstract}

The aim of this study was to evaluate the physical properties of denture liners after immersion in a sodium perborate's solution. In all the tests, both materials, Kooliner and Elite soft, were divided into the groups G1 (control): immersion in artificial saliva at $37^{\circ} \mathrm{C}$ and G2 (experimental): daily immersions in a sodium perborates's solution (Corega Tabs) for five minutes. Thirty specimens (diameter of $15 \mathrm{~mm}$ and thickness of $3 \mathrm{~mm}$ ) were obtained for the tests of water sorption, solubility, color change and hardness. Each material was processed according to the manufacturer's directions in metallic moulds prepared for this purpose and compressed by two glass plates. Water sorption and solubility were evaluated after 120 of immersion. Color change was evaluated after specimens' finishing, after thirty and sixty days of immersion. Kruskal Wallis $(\mathrm{P}<0,05)$ indicated that the immersion in sodium perborate $(G 1=1,43 ; G 2=1,63)$ did not interfere in the water sorption values. Sodium perborate promoted significative raise in the Elite soft's water sorption (G1=0,29; G2=0,51). Comparing the materials, Kooliner had the biggest means in both groups. In the solubility test, ANOVA $(\mathrm{P}<0,05)$, using two variation factors, indicated signifficant difference between groups and materials. Kooliner $(0,168)$ and Group $1(0,137)$ presented the biggest solubility means when compared with Elite soft $(0,089)$ and Group $2(0,110)$. Both materials changed between 30 (Kooliner: G1=3,63, G2=2,87; Elite soft: G1=6,27, G2=6,01) and 120 (Kooliner: G1=4,21, G2=3,94; Elite soft: $\mathrm{G} 1=8,54, \mathrm{G} 2=9,23$ ) days of immersion in the color test (Anova, $\mathrm{P}<0,05$ ). To the Kooliner's hardness, the ANOVA with two variation factors, indicated signifficant differece only for the time of immersion (grupo: $\mathrm{G} 1=6,63$; G2=7,27 e tempo: T0=5,24; $\mathrm{T} 30=7,28 ; \mathrm{T} 60=8,34)$. Comparing the means (Tukey=0,87) a signifficant raise $(\mathrm{P}<0,05)$ of the hardness was observed between all the periods evaluated. Specimens of the experimental group of Elite soft $(49,18)$ showed a raise $(\mathrm{P}<0,05)$ in the hardness when compared to the control group $(48,72)$. The test of Tukey $(0,76)$ indicated significant difference $(P<0,05)$ in the time of immersion between the three means $(\mathrm{T} 0=46,45$; $\mathrm{T} 30=49,63$; $\mathrm{T} 60=50,74)$. Sodium perborate did not influence significantly the properties evaluated in this study. Between the materials, Kooliner presented the best stability. But both materials have different compositions and behave in different ways clinically. The period of immersion is a very important factor in the physical properties of the materials; and all of them presented signifficant differences during this period. Studies with the intention of improving the materials' properties for a long term use should be tried to make viable the use of denture liners.

Key Words: Complete Dentures, Liners, Hygien, Physical Properties. 


\section{SUMÁRIO}

\section{RESUMO}

ABSTRACT

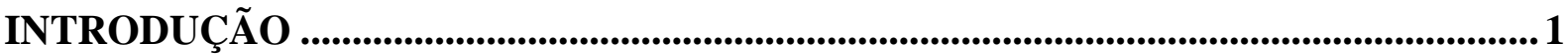

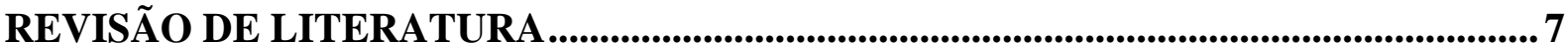

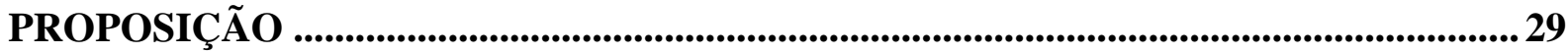

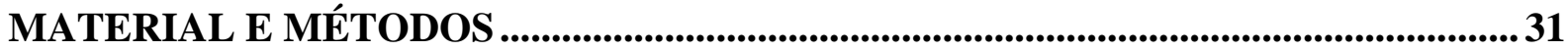

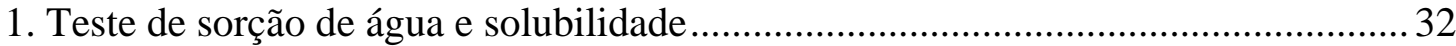

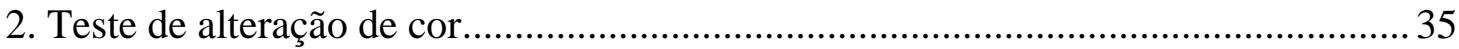

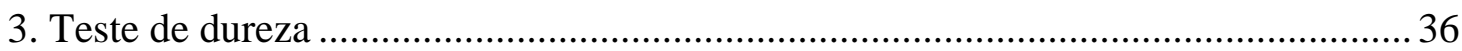

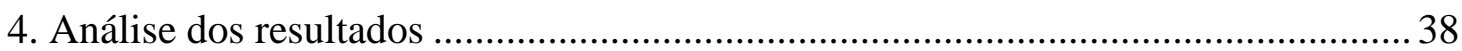

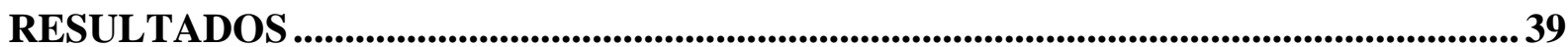

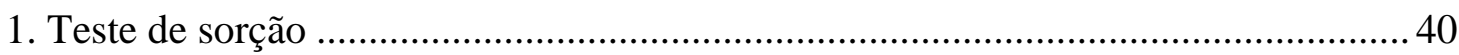

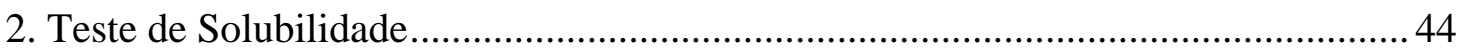

3. Teste de alteração de cor............................................................................................. 47

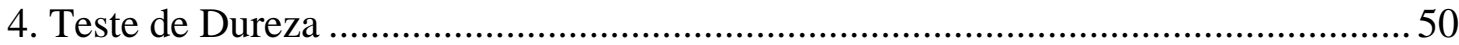

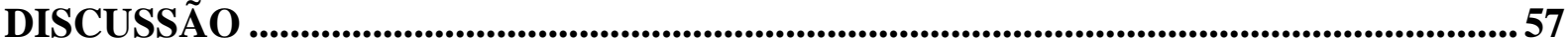

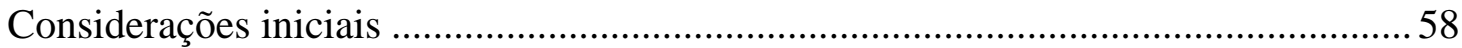

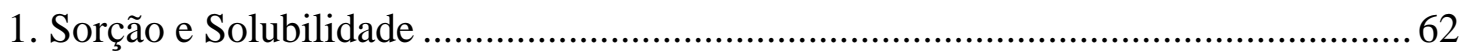

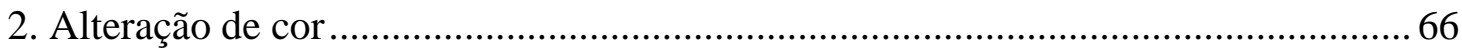

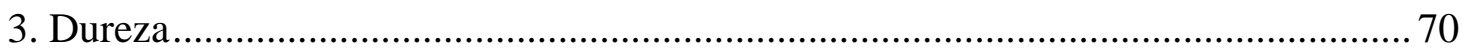

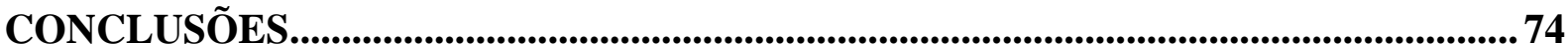

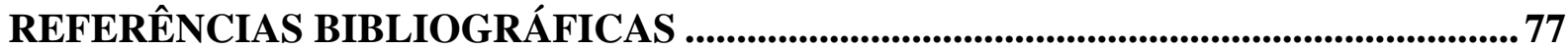

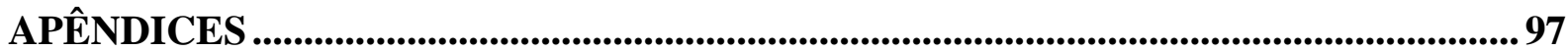

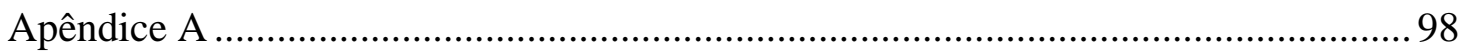

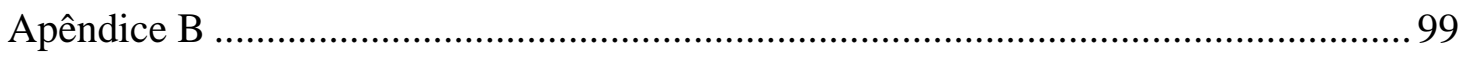

Apêndice C ........................................................................................................ 100

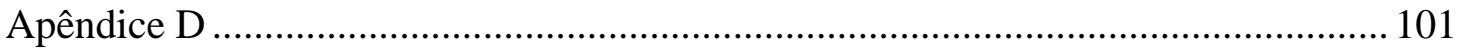




\section{INTRODUÇÃO}

A busca por uma melhor qualidade de vida para os pacientes edentados totais levou ao desenvolvimento de estudos e materiais que buscam melhorar a adaptação das dentaduras completas ao rebordo residual. O material comumente utilizado para a confecção das bases das próteses totais é a resina acrílica ativada química ou termicamente. Este material apresenta várias características e propriedades desejáveis como estética satisfatória, boa resistência, baixo custo e facilidade de manipulação (PHILLIPS, 1984). Entretanto, por ser rígido, pode causar lesões aos tecidos bucais. Como alternativa, surgiram os reembasadores resilientes, também conhecidos como bases macias ou "soft liners”.

O uso clínico de materiais reembasadores macios para próteses totais foi citado pela primeira vez em 1943. Desde então o seu uso tem se tornado cada vez mais popular por promover maior conforto aos usuários de dentaduras devido à sua capacidade de sorção de forças (GOLL; SMITH; PLEIN, 1983; NIKAWA et al. 1994a) distribuição da carga funcional sobre o rebordo (AYDIN et al., 1999; SINOBAD et al., 1992) e de adaptação da superfície protética e retenção da prótese (CRAIG; GIBBONS, 1961). Além disso, estes materiais têm sido utilizados nos tratamentos de rebordo atrofiado, bruxismo, xerostomia, e em próteses antagônicas à dentição natural (BOUCHER; HICKEY; ZARB, 1975).

Os reembasadores resilientes podem ser divididos em dois tipos principais: acrílicos plastificados e elastômeros de silicone (POLYZOIS; FRANGOU, 2001). Ambos são encontrados nas formas autopolimerizáveis e termopolimerizáveis. Os materiais acrílicos geralmente são constituídos de pó e componentes líquidos (STORER, 1962). As composições do pó e do líquido não são bem documentadas, mas acredita-se que eles sejam polímeros acrílicos e copolímeros, associados ao monômero acrílico e plastificadores (álcool etílico e/ou acetato etílico). 
A literatura informa que a maleabilidade inicial dos acrílicos plastificados resulta da grande quantidade de plastificadores no líquido e que estes são responsáveis pela manutenção da maleabilidade do material (MURATA et al., 2001a; MURATA et al., 2001b). O objetivo do plastificador é abaixar a temperatura de transição vítrea para um valor abaixo da temperatura da boca de um modo que o módulo de elasticidade do material resiliente seja reduzido a um nível satisfatório.

A composição dos elastômeros de silicone é similar às dos materiais de impressão de silicone. Eles são basicamente polímeros dimetilsiloxano. Polidimetilsiloxano é um líquido viscoso que pode formar ligações cruzadas resultando em uma borracha com boas propriedades elásticas. Nenhum plastificador é necessário para produzir um efeito de maleabilidade (QUDAH; HUGGETT; HARRISON, 1991).

Os requisitos necessários para os reembasadores resilientes de longa duração são resiliência permanente, alta estabilidade dimensional (baixa sorção de água e solubilidade), boa adesão à base da prótese (WRIGHT, 1982), adequada resistência à ruptura (QUDAH; HARRISON; HUGGETT; 1990), estabilidade de cor e compatibilidade com os tecidos orais. Uma vez que os reembasadores de próteses estão em contato direto com os tecidos orais, eles devem ser atóxicos, não irritantes e incapazes de sustentar crescimento bacteriano e fúngico (ANUSAVICE, 1996; CAUSTON, 1997).

No entanto, os materiais avaliados atualmente têm sido incapazes de reunir todos estes requisitos apresentando diversos problemas como estabilidade de cor, perda da resiliência em longo prazo, porosidade (NIKAWA et al., 1994a; DAVENPORT; WILSON; BASKER, 1978), colonização por Candida albicans (NIKAWA et al., 1994a; DAVENPORT; WILSON; BASKER, 1978; ZISSIS et al., 2000), perda de plastificadores e outros materiais solúveis, sorção de água ou saliva (AMERICAN DENTAL ASSOCIATION, 1975) e fratura em curto 
prazo (HARGREAVES, 1969; QUDAH; HARRISON; HUGGETT; 1990).

A estabilidade de cor é uma característica requerida dos polímeros das bases das próteses, quer sejam acrílicos rígidos ou materiais reembasadores resilientes, sendo especificada por várias normas nacionais e internacionais assim como a Especificação nº 12 da ADA (1975).

A mudança da cor pode ser considerada como um indicador, para os profissionais, do envelhecimento ou do dano de um material (MAKILA; HONKA, 1979; POLYZOIS et al., 1997). Alguns autores têm investigado as alterações de cor de reembasadores resilientes por meio de seu envelhecimento e notado grande alteração em suas propriedades, particularmente reembasadores de acrílico, causadas pela sorção de água ou solubilização em água destilada em períodos de 4 a 8 meses (MAKILA; HONKA, 1979; KAZANJI; WATKINSON, 1988; WAGNER et al., 1995).

Como fatores para a alteração de cor dos materiais reembasadores podem ser citados: acúmulo de manchas, desidratação, sorção de água, escoamento, fraca união e rugosidade superficial (POWERS; DENNISON; KORAN, 1978; NIMEROFF, 1968), desgaste ou degradação química (POWERS; BARAKAT; OGURA, 1985) e contínua formação dos produtos de degradação coloridos (POWERS; FAN; RAPTIS, 1985). A sorção de água e a solubilidade de materiais reembasadores resilientes podem causar aumento de volume; alteração dimensional gerando estresse na interface entre o reembasador e a base da prótese, levando ao aparecimento de “Gaps" entre a união dos dois materiais e à conseqüente proliferação de Candida albicans (WATERS; JAGGER; WINTER, 1996; EMMER et al., 1995; EICK; CRAIG; PEYTON, 1962); alteração de cor (POWERS; DENNISON; KORAN, 1978; NIMEROFF, 1968) e aumento da dureza, e diminuição da resiliência do material (PARKER et al., 1997). 
Durante o uso clínico, reembasadores macios são imersos em saliva e durante a estocagem da prótese, normalmente eles são deixados em uma solução higienizadora aquosa ou em água. Frente a estas imersões, estes materiais apresentam duas respostas: plastificadores e outros componentes solúveis são liberados e água ou saliva é absorvida (AMERICAN DENTAL ASSOCIATION, 1975). Já foi demonstrado (BATES; SMITH, 1965; WRIGHT, 1976; BRADEN; WRIGHT, 1983) que estes processos têm um efeito direto no desempenho dos reembasadores na boca; logo, um material ideal deveria ter baixa sorção de água e não possuir componentes solúveis.

Em pacientes dentados, o fluxo salivar e o atrito da língua limitam o acúmulo de microorganismos. Em usuários de próteses, estas impedem este fluxo, facilitando o estabelecimento de uma infecção focal pela retenção de Candida albicans na superfície do assentamento basal. Candida albicans é um microrganismo oportunista e a maior causa da Candidíase Atrófica Crônica (Estomatite protética), uma inflamação dos tecidos que sustentam as dentaduras (BUDTZ-JORGENSEN, 1974). A aderência é crítica para a patologia da C. albicans, servindo como o primeiro passo para a infecção por muitos microorganismos (CALDERONE; BRAUN, 1991; CUTLER, 1991). Já foi demonstrado que o principal reservatório de Candida albicans e as espécies Candida relacionadas é a superfície de adaptação da prótese superior (DAVENPORT, 1970; NIKAWA et al., 1992) e que materiais reembasadores resilientes são facilmente colonizados e profundamente infectados por estes organismos (ALISSON; DOUGLAS, 1973; DOUGLAS, 1979; NIKAWA; YAMAMOTO; HAMADA, 1995). Foi demonstrado clinicamente que, a contínua aspiração de microorganismos do biofilme da dentadura expõe os pacientes, particularmente os hospedeiros imunodeprimidos ou idosos sob ação de medicamentos, a riscos de infecções inesperadas (NIKAWA; HAMADA; YAMAMOTO, 1998). 
Os dois métodos de controle do biofilme da prótese total são classificados em métodos mecânicos (escovação e ultra-som) e métodos químicos (glutaraldeído 2\%, hipoclorito de sódio diluído, hipoclorito de sódio 5,25\%, dióxido de cloro, iodóforos, álcoois e clorexidina) (BELL et al., 1989; BRACE; PLUMMER, 1993; CHAU et al, 1995; RUDD et al., 1984; SHEN; JAVID; COLAIZZI, 1989;). A escovação é o método mais comumente empregado entre os usuários de próteses totais (LOVE; GOSKA; MIXSON, 1967; NIKAWA et al., 1999a; PARANHOS; PARDINI; PANZERI, 1991; POLYZOIS, 1983). No entanto, não é o método mais indicado para higiene das próteses que apresentam materiais resilientes, uma vez que podem danificar a superfície dos mesmos. Os higienizadores químicos são considerados métodos eficazes para prevenir a proliferação dos microrganismos do biofilme (DAVENPORT; WILSON; SPENCE, 1986; HARISSON, BASKER, SMITH, 1989; NIKAWA et al., 1999a), porem, o uso diário destes produtos pode afetar negativamente as propriedades físicas das bases de resina acrílica associadas aos reembasadores resilientes (BROGNIEZ et al., 1989; GOLL; SMITH; PLEIN, 1983; HARISSON, BASKER, SMITH, 1989; NIKAWA et al. 1994a).

A utilização de reembasadores resilientes tornou-se uma realidade na confecção de próteses totais. No entanto, não se sabe ao certo qual é o tipo de reembasador resiliente mais adequado e qual sofre menores influências em suas propriedades pelo uso de higienizadores químicos existentes no mercado brasileiro. 


\section{REVISÃO DE LITERATURA}

O uso clínico dos materiais reembasadores resilientes foi reportado pela primeira vez em 1943 por Tylman e em 1945 por Popper. Desde então o uso de reembasadores tem se tornado cada vez mais popular por promover conforto aos pacientes que usam próteses totais.

Para que um reembasador resiliente apresente sucesso clínico em longo prazo, Storer (1962) estipulou algumas propriedades desejáveis, tais como:

- não ser irritante e ser atóxico para a mucosa bucal, além de ser inodoro e insípido;

- ter estabilidade dimensional durante o processamento e o uso;

- apresentar mínima sorção de fluidos;

- apresentar alta resistência à abrasão;

- apresentar resiliência permanente;

- ter alta resistência de união ao material acrílico da base de próteses;

- apresentar processamento simples e ser de fácil reparo.

Segundo o autor, os reembasadores resilientes ainda não preenche estes requisitos e dessa forma, não solucionam todos os problemas causados pelas próteses totais. Por isso, é necessário que se atente à correta extensão das bordas, ao desenvolvimento correto da oclusão e a articulação dental equilibrada e homogênea quando da reabilitação protética de pacientes edentados totais com prótese total convencional.

As normas da American Dental Association (1983) salientaram a importância da utilização dos agentes de limpeza e desinfecção das próteses. Os agentes de limpeza são formulados com base em agentes abrasivos, como pastas, e em agentes oxidantes como o hipoclorito e os peróxidos. O hipoclorito de sódio pode ser usado como desinfetante, uma vez que dissolve ou solubiliza o material orgânico presente nas próteses e pode atuar sobre 
manchas promovendo o branqueamento. Os peróxidos apresentam uma combinação de um agente, como o perborato de sódio e de um detergente alcalino, como o fosfato tri sódico. Quando a esses componentes é acrescentada a água, ocorre a produção de uma solução alcalina de peróxido de hidrogênio. Além disso, são incorporados nessa formulação, agentes oxidantes para proporcionarem ação de limpeza e remoção de manchas. Por outro lado, os agentes de limpeza podem causar efeitos deletérios sobre os componentes da prótese. Entre estes efeitos estão: alteração da cor, aumento da porosidade interna, aumento da rugosidade superficial e perda da resiliência.

Azevedo et al. (2005) realizaram um estudo onde o grau de conversão de duas resinas autopolimerizáveis para reembasamento (Duraliner II-D e Kooliner-K) e de uma resina termopolimerizável para base de prótese (Lucitone 550-L) foi avaliado, indiretamente, por meio da mensuração da dureza. O efeito da imersão em água s sobre essa propriedade também foi analisado. Após a polimerização, amostras (diâmetro - $5 \mathrm{~mm}$; espessura $-2 \mathrm{~mm}$ ) foram armazenadas a seco em temperatura ambiente e a dureza Vickers (VHN) foi mensurada após 0, 2, 7, 30 e 90 dias. As amostras foram, então, imersas em água a $37^{\circ} \mathrm{C}$ e a dureza foi avaliada nos períodos citados. Cinco amostras foram preparadas para cada material. Os resultados foram analisados utilizando-se o teste de Kruskal-Wallis $(\mathrm{P}<0,01)$. Para o armazenamento a seco, o material L apresentou aumento significativo na dureza $(\mathrm{P}<0,01)$ de $0(\mathrm{VHN}=23,2)$ para 30 dias $(\mathrm{VHN}=27,1)$, após o qual nenhuma diferença significativa foi observada. Aumento contínuo na dureza foi observado para o material D de $0(\mathrm{VHN}=4,6)$ para 90 dias $(\mathrm{VHN}=7,3)$. Para o material $\mathrm{K}$, aumento na dureza foi observado até 7 dias $(\mathrm{VHN}=9,2)$ quando ocorreu a estabilização $(\mathrm{P}>.01)$. Após 2 dias de armazenamento em água, todos os materiais apresentaram redução significativa na dureza $(\mathrm{P}<0,01)$. A dureza dos materiais avaliados aumentou durante o armazenamento a seco e diminuiu após a imersão em 
água.

Bascom (1966) realizou um estudo in vivo durante 27 meses com materiais resilientes visando avaliar a consistência tecidual, a reação dos pacientes, a descoloração e pigmentação, o endurecimento e as mudanças superficiais ocorridas nestes materiais. Como avaliação geral, o autor observou que a consistência tecidual permaneceu excelente na maioria dos pacientes, sendo que a reação deles variou bastante, desde relatos de uma melhoria muito grande até uma discreta diferença. Foi observado, em todas as próteses revestidas com acrílicos macios e em $86 \%$ das revestidas com borracha de silicone, algum grau de descoloração. O endurecimento gradual foi observado em todas as próteses revestidas com acrílico macio, exceto em uma e não houve endurecimento em nenhuma das próteses revestidas com borracha de silicone. Já em relação às mudanças de superfície, a borracha de silicone tornou-se grosseiramente áspera em todas as próteses que utilizavam este material de revestimento. Não foi observada nenhuma alteração naquelas revestidas por acrílicos macios. Não houve também, problemas relacionados com a adesão nas próteses confeccionadas com silicone, porque foram observados os devidos cuidados durante o processamento das mesmas.

Craig e Gibbons (1961) analisaram a dureza, alteração de peso, resistência de união, resistência ao rasgamento e estabilidade de cor em reembasadores resilientes. Para o estudo de dureza foi utilizado o Durômetro Shore A, 24 horas após o seu processamento e diariamente durante 20 semanas em amostras armazenadas em água destilada. $\mathrm{O}$ valor sofreu grande variação entre as marcas comerciais testadas. Alguns materiais chegaram a ter seu valor próximo ao de uma base rígida de resina acrílica. A alteração de peso foi realizada a cada 48 horas utilizando uma balança analítica. Com exceção do Flexene, todos os materiais apresentaram aumento no peso, o qual variou de $0,6 \%$ a $4,3 \%$, após quatro semanas de imersão em água destilada. A resistência de união e ao rasgamento foram determinados em 
máquinas de ensaios mecânicos Instron, com velocidade de $25 \mathrm{~cm} / \mathrm{min}$. Os valores foram determinados após 48 horas para que se completasse o tempo de polimerização de cada material. Quanto à resistência de união, todos os materiais apresentaram diminuição dos valores com o passar dos dias. Já a resistência ao rasgamento teve seus valores aumentados após a estocagem. A estabilidade de cor foi avaliada por dois métodos: a) exposição do material a uma lâmpada de luz ultravioleta por 24 horas; b) teste de estocagem das amostras em água destilada a $26^{\circ} \mathrm{C}$ por vinte semanas. Em alguns materiais o teste mostrou ausência da alteração de cor, já em outros as alterações variaram de moderadas a severas.

Davenport, Wilson e Spence (1986) avaliaram a compatibilidade dos limpadores de próteses com as bases resilientes e discutiram quais os melhores métodos de limpeza para esses materiais. Foram utilizados: Molloplast-B (base de borracha de silicone polimerizada pelo calor), Coe Super-Soft (resina acrílica polimerizada pelo calor) e Softic 49 (resina acrílica polimerizada por calor). Os produtos selecionados para limpeza foram: Toots Denture Cleanser (peróxido alcalino), Deepclean (ácido sulfâmico), Denclen (ácido mineral) e Dentural (hipoclorito alcalino). As amostras foram preparadas em matriz metálica cilíndrica, com $12 \mathrm{~mm}$ de diâmetro e $2 \mathrm{~mm}$ de espessura, e na base de cada uma foi colocada uma placa de Perspex, e sobre o material, uma base de polietileno. Cada amostra foi confeccionada de acordo com as instruções de seus respectivos fabricantes e as amostras resultantes consistiam em um disco de base resiliente sobre uma base de Perspex. Três amostras de cada material foram submersas em soluções de cada produto de limpeza. Alem disso, seis amostras foram imersas em em água a $37^{\circ} \mathrm{C}$ como grupo controle. As alterações visuais, a suavidade e a recuperação elastica das amostras testadas foram comparadas com o grupo controle. Após 5 semanas, a única alteração visual era o clareamento do Mollplast-B imerso em solução do Deepclean, sendo detectado já no sexto dia de imersão. Quanto à suavidade, o autor verificou 
apenas um leve aumento, mas nada significante, na suavidade após imersão nas soluções de limpeza. A recuperação elástica demonstrada pelo Molloplast-B após a imersão foi maior que a obtida pelos outros materiais. Dessa forma, o autor determinou que a utilização de soluções de limpeza é efetiva na remoção de biofilme e prevenção na formação de colônias de bactérias sem que ocorra deterioração destes materiais.

El-Hadary e Drummond (2000) estudaram a sorção de água, comparando os resultados entre um reembasador de silicone (Luci-soft) e um reembasador de resina acrílica plastificada (Permasoft). Foram utilizadas, duas técnicas de processamento, a laboratorial e a autopolimerizada para a confeccao de 24 discos (45mm de diâmetro e $1 \mathrm{~mm}$ de largura), os quais foram armazenados em água destilada a $37^{\circ} \mathrm{C}$ e testados após 1,4 e 6 semanas. Os discos usados na primeira semana foram testados novamente após 4 e 6 semanas de contínuo armazenamento. O ganho de peso foi calculado: Permasoft $(2,45 \% \pm 0,36 \%$ processados em laboratório e $1,76 \% \pm 0,08 \%$ autopolimerizado), Lucisoft $(0,41 \% \pm 0,17 \%)$ após 6 semanas de armazenamento. Os autores concluíram que Lucisoft possui maior sucesso clínico pois apresenta os valores mais baixos para sorção de água.

Feitosa et al. (2003) avaliaram perda de peso do material resiliente Coe-Soft quando submetido a tratamentos com os limpadores químicos para próteses Polident e Efferdent. Foram confeccionados 48 espécimes do material resiliente e divididos aleatoriamente em quatro grupos, dois controles (G1 e G2) e dois experimentais (G3 e G4), armazenados em saliva artificial à temperatura de $37 \pm 2^{\circ} \mathrm{C}$ durante todo o período estudado. Os espécimes dos grupos G1 e G2 foram imersos diariamente em água, e os grupos G3 e G4 foram imersos nas soluçöes de Polident e Efferdent, por 5 e 15 minutos, respectivamente, durante um período de 15 dias. As avaliaçöes de peso foram realizadas imediatamente após a confecçäo das amostras (T0), após 24 horas (T1), com 7 dias (T2) e 15 dias (T3). De acordo com as condições 
experimentais e os resultados obtidos, concluiu-se que o material reembasador resiliente CoeSoft, quando imerso em saliva artificial, perdeu peso antes de qualquer tratamento com os agentes químicos para limpeza, e a perda de peso foi observada em todos os grupos no decorrer dos tempos avaliados, independentemente do meio de imersäo, näo havendo diferença significante entre os tratamentos realizados (AU).

Garcia et al. (2003) verificaram o aumento de peso e a força de tensão de tração de 2 materiais reembasadores resilientes, o Coe Soft e o Dentusoft. Ambos estavam aderidos a uma fina camada de resina acrílica quando imersos. Duas imersões foram utilizadas: 1imersão em higienizador de prótese total a base de enzimas (Polident) 2 - imersão em água. Para o teste de aumento de peso, foram preparados 20 espécimes de cada material reembasador em forma de discos, pesados e estocados em saliva artificial. Após 24 horas, foram retirados da saliva e estocados em água de torneira (grupo controle) e o restante foi imerso em Polident por 5 minutos até o fim de 15 dias. O peso foi anotado imediatamente após a confecção dos corpos-de-prova (T0) e após 24 horas (T1), 7 dias (T2) e 15 dias (T3) de imersao. O Coe Soft imerso em Polident perdeu peso após 24horas, e após 7 e 15 dias ganharam peso. Resultados similares foram obtidos com o Dentusoft. O Dentusoft perdeu mais peso nas duas imersões durante T0 e T1 do que o Coesoft. Os materiais reembasadores podem absorver água ou perder componentes solúveis dependendo de sua composição e do meio de solução a que são submetidos. Os espécimes imersos em Polident demonstraram aumento maior no peso do que quando estocados em água.

Hayakawa et al. (2006) investigaram várias propriedades importantes clinicamente de um novo produto para reembasamento de próteses totais (Maxfit) e comparou suas propriedades com as de outros 3 produtos comerciais (Kooliner, Tokuyama Rebase e Denture Liner. A sorção de água $\left(\mathrm{mg} / \mathrm{mm}^{3}\right)$ e a solubilidade $\left(\mathrm{mg} / \mathrm{mm}^{3}\right)$ foram testadas de acordo com 
International Organization for Standardization (ISO) Standard No. 1567. A resistência ao manchamento foi avaliada pela mensuração da alteração de cor (DE) após imersão em 2 soluções (café e solução vermelha). A dureza foi determinada usando teste Knoop de acordo com American National Standards Institute/American Dental Association Specification No. 17. Os dados foram analisados por meio de estatística não-paramétrica (Kruskal-Wallis, $\mathrm{a}=.05$; e teste de Mann-Whitney U combinado com Bonferroni, a=.008). O material Maxfit apresentou os menores valores de sorção e solubilidade $\left(8.06 \pm 0.1,0.5 \pm 0.1 \mathrm{mg} / \mathrm{mm}^{3}\right.$, respectivamente). A alteração de cor do Maxfit pelas duas soluções café foi significativamente menor que do Tokuyama Rebase e do Denture Liner $(\mathrm{P}<.001)$. A dureza Knoop do Maxfit $(8.66 \pm 0.51)$ foi maior que a do Kooliner e Tokuyama Rebase $(\mathrm{P}<.001)$. Os autores concluíram que o novo material à base de fluoralquil-metacrilato (Maxfit) mostrou menor sorção e solubilidade de água e maior resistência ao manchamento. Por outro lado, a adição de fluoreto ao produto não impediu o aumento da dureza, comum em material reembasador.

Jin et al. (2003) avaliaram a rugosidade superficial e a alteração de cor de 6 reembasadores macios para próteses totais após a imersão em solução de higiene. Os materiais foram imersos na solução de higiene por 8 horas a temperatura ambiente, e imersos em água destilada para completar 24 horas a $37^{\circ} \mathrm{C}$, por um período de 180 dias. A rugosidade superficial foi mensurada por meio de um rugosímetro de contato (Surfcorder SE3300). A estabilidade de cor foi mensurada por um instrumento fotométrico (Chroma Meter34, CR321) e calculada por meio do sistema CIE LAB $(\mathrm{P}<0.01)$. O material a base de silicone autopolimerizável (Evatouch) exibiu severas alterações na rugosidade superficial após 
imersão em todas as soluções testadas (peróxido alcalino, peróxido neutro com enzima e enzimas) e o material GC Denture Relining apresentou as menores alterações.

Kazanji e Watkinson (1988) avaliaram a solubilidade e sorção em saliva artificial e água destilada dos materiais Softic 49, Coe Super-Soft, Coe Soft, Molloplast-B e Flexibase. Seis corpos-de-prova de cada material foram confeccionados com $45 \mathrm{~mm}$ de diâmetro e $1 \mathrm{~mm}$ de espessura. Após 48 horas as amostras foram pesadas com ajuda de balança analítica, e em seguida, três amostras de cada material foram imersas em saliva artificial e as outras três em água destilada à temperatura de $37^{\circ} \mathrm{C}$. As amostras foram subseqüentemente pesadas nos períodos de uma semana, 1, 4 e 8 meses, e as porcentagens de sorção e solubilidade foram determinadas. Os resultados mostraram que não houve diferença significante na solubilidade e sorção em saliva artificial ou água destilada para o Molloplast-B. Todos os outros materiais apresentaram maior solubilidade em saliva artificial do que em água destilada, provavelmente devido à maior solubilidade dos componentes plastificantes em soluções iônicas. Por outro lado, a porcentagem de sorção desses materiais foi maior em água do que em saliva artificial. Os autores concluíram que o Molloplast-B foi o material mais estável, e provavelmente possua maior durabilidade clínica.

Kiat-Amnuay et al. (2005) estudaram a influência da estocagem em água na dureza de cinco reembasadores macios (Luci-Soft, Molloplast-B, Tokuyama soft relining, Novus e Permasoft). Como o Permasoft possui em seu kit um selante, este material foi testado de três maneiras: a- sem aplicação do selante, b- com aplicação inicial do selante, c- aplicação do selante todo mês. Os corpos-de-prova produzidos foram estocados em água, que era trocada a cada duas semanas, a $37^{\circ} \mathrm{C}$. Os corpos-de-prova foram submetidos a um Durômetro Shore A2 após 16,7 minutos; 27,8 horas; 11,6 dias; 34,7 dias; 115 dias e 347 dias de imersão. Após os 
primeiros testes, o material que apresentou a maior maciez foi o Permasoft seguido do Tokuyama soft relining. Como resultados os autores encontraram que o Tokuyama soft relining foi o que menos alterou após os 347 dias de imersão. Depois na sequência vieram: Luci-Soft, Novus, Permasoft com aplicação inicial do selante, Molloplast-B, Permasoft sem aplicação do selante e Permasoft com aplicação mensal do selante. Então, os autores concluíram que o material que melhor respondeu à imersão foi o Tokuyama soft relining e que o Permasoft foi o que mais alterou sua dureza.

Lamie e Storer (1958) avaliaram a dureza, resistência à abrasão, sorção de água e adesão à base de resina acrílica de diferentes tipos de materiais macios utilizados em próteses totais como as borrachas naturais, cloreto de polivinil (Provinil-p Ultra e Vernasoft), polivinil acetato (Jospi), copolímero de metil-metacrilato (Plastupalat) e borrachas de silicone. O teste de dureza foi baseado na quantidade de penetração de uma barra rígida, sobre uma amostra do material resiliente com espessura de 0,8 a 1,0 cm e diâmetro de 5,12 cm. Os testes foram realizados antes da imersão em água e após intervalos regulares. O cloreto de polivinil foi considerado pelos autores como o material de escolha por possuir boa estabilidade dimensional durante o processamento, boa adesão à base de resina e baixa sorção de água. Já o polivinil acetato foi contra-indicado por perder seu componente plastificante, tornando-se rígido após alguns meses de uso. Os autores concluíram ainda, que os produtos à base de silicone são mais indicados para utilização clínica pela facilidade da técnica e pela baixa sorção de água.

Léon et al. (2005) compararam a sorção de água de dois materiais resilientes polimerizados por diferentes métodos, após serem submetidos a um ciclo térmico. Os materiais utilizados foram o Light Liner, polimerizado por luz visível e o Eversoft processado por 2 diferentes métodos: banho quente e energia de microondas. Foram fabricados 10 
espécimes em forma de disco para cada método de polimerização. Os espécimes foram secos e submetidos a 2000 ciclos térmicos com banho entre 5 e $55^{\circ} \mathrm{C}$. Em seguida foram pesados, secos e pesados novamente para o cálculo da sorção. Os resultados mostrados para a sorção de água não apresentaram diferenças significantes entre os 2 tipos de polimerização.

Louka, Gesser e Kasloff (1977) avaliaram o efeito de dois tratamentos de superfície em bases resilientes e sua relação com as propriedades de molhabilidade, sorção de água e retenção sob a base da prótese. Os materiais foram selecionados entre os mais comumente empregados, ativados quimicamente (SoftOryl, Flexacril e Mollosil) e termicamente (Palasiv e Molloplast-B) e foram utilizados de acordo com as condições dos fabricantes. Três grupos foram separados com 6 amostras para cada material. Grupo 1 - a superfície foi tratada com uma camada fina de sílica na superfície; Grupo 2 - foi utilizada a tecnologia de CoberturaHidroxyl; Grupo 3 - sem tratamento (grupo controle). A molhabilidade foi determinada com analisador para ângulos de contato. A sorção de água foi determinada através de alterações de peso após imersão em água destilada em diferentes períodos de tempo. Os dois tipos de tratamento superficial fizeram diminuir o ângulo de contato nas 2 primeiras semanas, melhorando assim as propriedades de cada material, com maior efeito para a CoberturaHidroxyl, com exceção da base SoftOryl que apresentou menor ângulo de contato quando tratado com o tetracloride de sílica, que também apresentou aumento na sorção de água para as diversas bases, o que não ocorreu no tratamento de Cobertura-Hidroxyl e nem com o grupo controle.

Ma, Johnson e Gordon (1997) realizaram um estudo clínico para verificar se o tempo de imersão para desinfecção química alteraria a textura superficial e a cor de 5 resinas para dentaduras. Foram utilizadas como soluções desinfetantes o Clorox, Banicide, Cidex-7, Biocide e Multicide combinadas com as resinas Dentsply reline material, Hygenic HyFlo, 
Hygenic Perm, Lucitone 199, e Triad VLC reline resin, em 4 diferentes períodos de imersão (10 minutos, 30 minutos, 24 horas e 7 dias). Mensurações iniciais e após os períodos de imersão nas respectivas soluções foram realizadas. Os dados foram analisados por meio de análise de variância e embora diferenças estatísticas tenham sido demonstradas entre os desinfetantes e as resinas para os dois parâmetros analisados, segundo os autores, a magnitude das alterações de rugosidade e cor foi clinicamente insignificante.

Makila e Honka (1979) realizaram um estudo in vivo para avaliar algumas propriedades de um material reembasador resiliente de silicone termopolimerizável (Molloplast-B), dentre as quais alteração de cor e dureza. Foram pesquisados 37 pacientes, utilizando próteses totais superior e inferior, todos com fibromucosa saudável. As investigações foram realizadas em 4 etapas, de 2 a 8 semanas, e após 6, 12 e 30 meses de instalação da prótese total. Quanto à análise da cor, as próteses foram comparadas com uma amostra de base resiliente de $2 \mathrm{~mm}$ unida em resina e armazenada em água e foram observadas alterações em 33 próteses (86\%). A cor vermelha da base apresentou descoloração durante o uso em 17 próteses (46\%). Foi observado também amarelamento em 16 próteses, sendo que em 10 casos progrediu para a cor laranja, marrom-claro, médio ou escuro, às vezes quase negro. Desses 10 casos, 8 usuários eram fumantes. Quanto ao endurecimento, em nenhuma prótese foi verificada esta alteração. Os autores observaram que a descoloração da base resiliente que aconteceu principalmente devido ao uso de agentes de limpeza e que houve o crescimento fúngico maior em próteses submetidas à escovação mais rígida, devido à formação de nichos, mostrando que a maior desvantagem da base resiliente é a dificuldade de manutenção da limpeza sem danificar o material.

Matsumura et al. (2001) avaliaram clinicamente a performance de um reembasador rígido autopolimerizável (Tokuso Reabase) após um ano de reembasamento. Utilizaram 50 
pacientes que necessitavam deste tipo de tratamento, avaliando apenas uma prótese de cada um deles. Se o antagonista também precisasse do reembasamento, este não era avaliado. A adaptação de cada prótese foi previamente avaliada com um material elastômero de silicone de consistência fluida. A superfície a ser reembasada recebeu os devidos desgastes e posteriormente foi condicionada com diclorometano. O reembasamento foi então realizado e as próteses foram avaliadas imediatamente e após um ano. Após a avaliação geral, os autores encontraram que a quantidade de casos que se apresentaram em condições clínicas ideais após um ano foram: $90 \%$ quanto ao manchamento, $90 \%$ quanto à descoloração, $94 \%$ quanto ao descascamento, 96\% quanto à adaptação e 100\% com relação à irritação aos tecidos orais. Então os autores concluíram que após um ano de observação, o Tokuso Rebase foi considerado um material confiável quanto a estes fatores.

Nikawa et al. (1994) estudaram os efeitos de higienizadores de próteses em materiais reembasadores macios. Para tal eles estudaram seis materiais (Coe Comfort, Coe Soft, Fit Softer, GC Soft Liner, Hydrocast e Viscogel), que foram imersos em doze higienizadores de próteses, de sete diferentes categorias (peróxidos alcalinos, peróxidos neutros com enzimas, enzimas, drogas brutas, ácidos, detergentes, higienizadores bucais). Os testes realizados para avaliar a deterioração dos materiais foram o de porosidade superficial e o de distorção. Os autores encontraram que o grau de porosidade dos materiais reembasadores variou dependendo do tempo de imersão e da combinação material reembasador com o higienizador. Os autores citaram que os efeitos dos higienizadores à base de peróxidos, com poucas excessões, causou mudanças mais severas do que os outros tipos. A conclusão do trabalho foi de que os clínicos devem escolher um material baseado não só nas suas propriedades microbiológicas, mas também no aspecto da compatibilidade do material higienizador com o material reembasador. 
Parr e Rueggeberg (2002a) realizaram um teste in vitro sobre a dureza de dois materiais reembasadores resilientes, um autopolimerizál (Tokuyama Soft Relining Paste) e o outro processado convencionalmente em laboratório (Luci-Soft); ambos após um ano de imersão em água. Os espécimes autopolimerizáveis foram confeccionados em forma de disco (31 mm x $10 \mathrm{~mm}$ espessura) em moldes de anéis de alumínio de acordo com orientações do fabricante. Os espécimes termopolimerizáveis foram fabricados empregando um anel de tamanho similar com uma mufla para dentadura convencional, sendo após, processado em água em ebulição por três horas e meia. No total foram obtidos 96 espécimes, das quais um lote completo não foi imerso em água, enquanto que o outro foi testado imediatamente após a estocagem em água destilada a $37^{\circ} \mathrm{C}$ por um período de um dia, uma semana, um mês e um ano. Para o teste de dureza abaixou-se uma haste vertical sob uma força de $1 \mathrm{~kg}$, a qual foi lentamente comprimida contra o centro dos espécimes e a maior leitura foi anotada. Foram obtidas três leituras para cada espécime. Os valores de dureza foram significativamente maiores para o material processado em laboratório do que para o autopolimerizável, a cada intervalo de tempo, após a polimerização. Os valores de dureza dos espécimes autopolimerizáveis foram constantes após uma semana de armazenamento em água, enquanto tais valores aumentavam de acordo com o tempo de imersão para os processados em laboratório.

Parr e Rueggeberg (2002b) propuseram uma análise in vitro sobre sorção de água dos materiais resilientes após um ano de armazenamento em água. Os materiais utilizados foram: o Lucisoft termopolimerizável (TP) (Dentsply International, York, P.a) e o Tokuyama Soft Relining Paste autopolimerizável (AP) (Tokuyama América, San Mateo, Calíf). Para o teste de sorção de água foram fabricados espécimes em forma de barra $(44 \times 8,5 \times 1,2 \mathrm{~mm}$ de espessura) utilizando diretamente o material da cápsula de mistura dentro de um molde de 
aluminio. O conjunto autopolimerizável foi prensado com aproximadamente $0,14 \mathrm{MPa}$ e autopolimerizado em temperatura ambiente por 20 minutos. O conjunto termopolimerizável foi polimerizado em água a $100^{\circ} \mathrm{C}$ por 3,5 horas. Após processamento e polimerização, os espécimes foram pesados em balança analítica, colocados em água destilada e estocados a $37^{\circ} \mathrm{C}$. A pesagem foi realizada em intervalos de 1 dia, 1 semana, 1 mês, 6 meses e 1 ano apos a colocação dos espécimes em um dessecador. Os valores de sorção dos materiais termo e autopolimerizáveis foram equivalentes após 6 meses e após um ano de estocagem em água.

Pavan et al. (2007) avaliaram os efeitos da desinfecção com soluções químicas (glutaraldeído a $2 \%$, hipoclorito de sódio a 5\% e clorexidina 5\%) e energia de microondas na dureza de 4 materiais reembasadores de longa duração para dentaduras. Foram confeccionados 40 espécimes retangulares de cada material (Molloplast-B, Ufi Gel P, Eversoft e Mucopren soft) sendo que 10 amostras foram imersas nas diferentes soluções por 10 minutos ou colocadas em forno microondas por 3 minutos a $500 \mathrm{~W}$ de potência. Os valores de dureza foram obtidos por meio de um durômetro Shore A antes do primeiro ciclo de desinfecção (controle) e após 2 ciclos de desinfecção. Os dados foram submetidos à Análise de Variância e Teste de Tukey $(\mathrm{P}<0.01)$. Os maiores valores de dureza foram obtidos com o Molloplast-B, independente da técnica de desinfecção. O Mucopren soft demonstrou valores intermediários e o Ufi Gel P e o Eversoft os menores valores de dureza Shore A. Para o Molloplast-Búmero de ciclos de desinfecção não teve efeito sobre a dureza dos materiais estudados e técnicas. A A utilização de dois ciclos de desinfecção não promoveu alteração da dureza Shore A dos materiais. A solução de glutaraldeído demostrou os maiores valores de dureza para o Molloplast-B, Mucopren soft, e Ufi Gel P. O Eversoft não apresentou diferença na dureza quando submetido aos diferentes métodos de desinfecção. 
Pesun et al. (2001) avaliaram uma técnica não destrutiva para testar a resiliência de um reembasador para uso prolongado à base de silicone. Amostras com espessura de 1,$1 ; 2, .2$; 3,3; e 4,4 mm de dois materiais (MPDS-SL, Lai Laboratories, Inc, Burnsville, MN; e Molloplast-B, Buffalo Dental, New York, NY) foram avaliados por meio de sistema servohidráulico aplicando uma força de $3 \mathrm{lb}$. A força e os valores foram registrados usando um osciloscópio, cujos valores foram analizados com um auxílio de software para determinar os valores de resiliência. $\mathrm{O}$ efeito da espessura do material foi avaliado pelo teste wedges dos dois materiais. A técnica utilizada mostrou que diferentes espessuras promoveram diferenças significantes nos valores de resiliência $(\mathrm{P}<.0001)$. Entre os materiais utilizados para avaliar a técnica o MPDS-SL apresentou maior elasticidade que o Molloplast-B $(\mathrm{P}<.0001)$. A espessura de 2,2 mm não aumentou a resiliência, embora o MPDS-SL had a steeper thicknesscompliance curve than Molloplast-B. O método usado promoveu sensibilidade suficiente para avaliar os dois materiais nas diferentes espessuras. A sensibilidade e a natureza não destrutiva do teste mostrou que tem aplicabilidade para avaliação clínica de reembasadores resilientes.

Pinto et al. (2002) determinaram o efeito da termociclagem sobre a deformação permanente dos materiais reembasadores resilientes Eversoft composto por polimetilacrilato e Mucopren soft composto por base resiliente de silicone. Matrizes cilíndricas metálicas foram confeccionadas, colocadas lado a lado em uma mufla, fixadas com gesso pedra tipo III e cobertos com silicone de inclusão. A contra-mufla foi preenchida com gesso pedra tipo III e fechada. Após a demuflagem, o molde impresso na superfície do silicone foi preenchido pelos materiais reembasadores, totalizando 20 amostras de cada material. Metade da amostra, para cada material, foi armazenada por 24 horas em água destilada a $37^{\circ} \mathrm{C}$ na estufa e outra metade foi submetida a ciclos térmicos. Então, as amostras foram submetidas a cargas compressivas e indicou-se a leitura da deformação e recuperação elástica. A importância do ensaio está na 
indicação da falta de recuperação elástica do Eversoft quando comparado com o Mucopren soft, pois o Mucopren soft não apresentou diferença significativa após tratamento térmico, já para o Eversoft a deformação permanente foi maior após o ciclo térmico.

Polyzois e Frangou (2001) realizaram um estudo para avaliar a dureza de resina acrílica resiliente e de materiais para forramento com o passar do tempo quando procedimentos de polimerização foram alterados e quando seladores de superfície foram ou não utilizados. Foram obtidos discos de $40 \mathrm{~mm}$ de diâmetro e $10 \mathrm{~mm}$ de espessura. Os materiais foram polimerizados em água aquecida, elevando-se a temperatura e em temperatura ambiente (boca). Cinco amostras foram usadas para cada método de processamento. Metade das amostras foi tratada com um selador de superfície, enquanto a outra metade das amostras não recebeu qualquer tratamento de superfície. Depois de processadas, as amostras foram imersas em $37^{\circ}$ água por 1 ano. A dureza dos espécimes foi avaliada mensalmente, com o auxílio de um Durômetro Shore A. Os corpos-de-prova apresentaram diferenças de dureza relacionadas ao material e ao tempo após o processamento. A resina para forramento termopolimerizada mostrou um aumento significativo da Dureza Shore A no decorrer do período experimental $(\mathrm{p}<.01)$. O aumento da dureza foi observado em todos os materiais com o passar do tempo, mas este aumento foi mais pronunciado com o material de forramento. $\mathrm{O}$ tratamento de superfície manteve a maciez dos materiais somente quando as amostras foram polimerizadas em temperatura ambiente (simulando a temperatura da cavidade oral) $(\mathrm{p}<.05)$. O método de processamento e o tempo decorrido após o processamento causaram um efeito na dureza superficial dos materiais testados, mas nenhum destes fatores é tão importante quanto a escolha inicial do material.

Saraç et al. (2007) investigaram a estabilidade de cor de reembasadores resilientes e a efetividade de higienizadores de dentaduras na remoção de corantes alimentares depositados 
em reembasadores à base de resina acrílica (Viscogel) e à base de silicone (Mollosil), em diferentes períodos de tempo. Para cada material, 30 espécimes foram preparados em um molde de teflon de $15 \mathrm{~mm}$ de diâmetro e $3 \mathrm{~mm}$ de espessura e estocados em água destilada por 24 horas a $37^{\circ} \mathrm{C}$. A mensuração da cor inicial foi realizada por meio de um colorímetro para áreas pequenas. Os espécimes de cada material foram divididos em três grupos $(\mathrm{n}=10)$ para imersão por 14 horas ( 2 horas/7 dias) em eritrosina a 3\%, tartrazina e amarelo crepúsculo, corantes alimentares, para então ser realizada a segunda mensuração da cor. Em seguida, os espécimes de cada grupo foram divididos em dois subgrupos $(n=5)$ e foram imersos en higienizadores de dentaduras (Fittydent e Curadent Weekly) por 8 horas, e a terceira mensuração da cor foi realizada. Estes procedimentos foram realizadas até completar os 7 dias. Outras três mensurações de cor foram realizadas ao final da simulação de períodos de 1,2 e 3 meses. Os valores da alteração de cor $(\Delta \mathrm{E})$ foram calculados e os dados derivados foram analisados por meio de análise de variância "three-way" e Teste de Bonferroni para comparações múltiplas $(\alpha=0.05)$. Houve diferença significante entre os materiais e os higienizadores. O Mollosil demonstrou valores médios de descoloração $(\Delta \mathrm{E})$ entre 0,81 e 2,66; o Viscogel apresentou $\Delta \mathrm{E}$ entre 1,26 e 12,83, valores estatisticamente diferentes $(\mathrm{P}<0.001)$. Não houve diferença significante entre os corantes alimentares $(\mathrm{P}>0.05)$. Os higienizadores de dentaduras mostraram diferenças significantes $(\mathrm{P}<0.001)$, sendo o Fittydent promoveu menores valores de $\Delta \mathrm{E}$ que o Curadent. $\mathrm{O}$ material à base de silicone mostrou ser mais resistente ao manchamento. Com relação aos higienizadores o Fittydent foi mais efetivo que o Curadent.

Tan et al. (2000) comparam a cor, textura e dureza Shore A de um reembasador resiliente polimerizados e com a superfície polida e sem polimento, para próteses totais após tratamento com soluções higienizadoras. Cinqüenta e oito espécimes de cada tipo (polido e 
não polido) foram exposto a 5 soluções de higiene contendo perborato, persulfato ou hipoclorito a $25^{\circ} \mathrm{C}$ ou $55^{\circ} \mathrm{C}$, continuamente por 4 meses e meio. As soluções eram renovadas 2 vezes por dia. Um grupo controle foi mantido em água. Antes e após os 4 meses e meio, a cor, a dureza e a textura superficial do reembasador foi avaliada por meio de um densitómetro de cor, um durômetro Shore A (Shore Instrument \& Mfg Co, Freeport, NY), e um rugosímetro de superfície, respectivamente. Diferença entre os grupos após o tratamento com o higienizador foi detectada por meio da análise de variância $(\mathrm{p}<0.05)$ e Teste de Tukey. A superfície rugosa dos espécimes após tratamento com o higienizador a $25^{\circ} \mathrm{C}$ ou $55^{\circ} \mathrm{C}$ exibiu alteração significante na cor com o higienizador contendo perborato quando comparado ao grupo controle e ao grupo do persulfato. Os espécimes com a superfície rugosa do grupo do perborato apresentaram dureza significativamente maior quando comparado com o grupo do hipoclorito a $25^{\circ} \mathrm{C}$. Não foram encontradas diferenças na textura da superfície após os tratamentos. Os autores concluíram que, após o tratamento do material resiliente com soluções contendo perborato, uma maior quantidade de componentes do material é perdido para a solução levando a uma maior alteração de cor dos espécimes sem polimento.

Villar et al. (2003) avaliaram clinicamente um novo material resiliente para reembasamento para próteses totais (MPDS-SL; Lai Laboratories, Burnsville, MN) e o Molloplast-B (Buffalo Dental Manufacturing, Syosset, NY) quanto à resiliência e alteração de cor por um período de um ano. Em um estudo “crossover", 20 pacientes tiveram duas próteses totais confeccionadas com os materiais resilientes, uma com Molloplast-B e outra com MPDS-SL. Cada prótese foi utilizada por 6 meses e durante este período os pacientes relatavam em um diário os detalhes de seus hábitos de uso e higiene. Os testes foram realizados no início do experimento e após 3 e 6 meses de uso das próteses. A resiliência foi determinada pela aplicação de uma força de 3-lb sobre a superfície do material usando um 
sistema servohidráulico. A força e os valores foram registrados por meio de um osciloscópio. A resiliência foi avaliada em três pontos das dentaduras e analisada por meio de um software para aquisição dos dados. Imagens das dentaduras foram obtidas por meio de estereomicroscópio com uma câmera de vídeo acoplada e a imagem foi analisada com o auxílio de um software (Photoshop). A cor também foi mensurada em três pontos das próteses; o RGB e os valores de $\mathrm{L}^{*} \mathrm{a}^{*} \mathrm{~b}^{*}$ foram calaculados. A resiliência aumentou nos intervalos de 3 e de 6 meses em quase todos os pontos em ambos os materiais. O MolloplastB (284 \pm 46$)$ e o MPDS-SL $(453 \pm 46)$ apresentaram diferenças $(\mathrm{P}=0,019)$ nas médias de resiliência ao longo dos 6 meses. Para os dois materiais a alteração de cor foi significante após 3 e 6 meses $(\mathrm{P}<0.01)$. O MPDS-SL sofreu alteração significantemente menor que o Molloplast-B ao longo dos 6 meses. Para ambos os materiais a compliance increased após 6 meses de uso. A alteração de cor para o MPDS-SL foi consideravelmente menor que a do Molloplast-B.

Wright (1976) estudou os materiais macios para reembasamento de próteses com o intuito de determinar qual o melhor material, como melhor utilizá-lo e como podem ser aperfeiçoados. Após levantamento da literatura, o autor selecionou 12 marcas comerciais e, em seguida, as dividiu em dois grupos: 1- Materiais à base de silicone (Flexibase, MolloplastB, Simpa, Cardex-Stabom e Per-Fit); 2- Materiais à base de resina acrílica (Coe-Soft, SoftOryl, Coe Super Soft, Palasiv 62, Soft Nobeltone, Virina e Verno Soft). Todos os materiais foram submetidos à análise de sorção de água, solubilidade, propriedades viscoelásticas, e ainda as amostras foram submetidas a oscilações sinusoidais utilizando-se um pêndulo sob freqüência variável de 0,05 a $0,5 \mathrm{~Hz}$, à temperatura ambiente. $\mathrm{O}$ autor concluiu que os resultados das propriedades viscoelásticas não apontaram um produto mais adequado do que outro, no entanto, os materiais à base de silicone permaneceram por um 
maior período de tempo com suas características resilientes. Por outro lado, estes materiais apresentaram pobre adesão em relação aos materiais resilientes de resina acrílica.

Yilmaz et al. (2005) estudaram a efetividade de quatro soluções desinfetantes diferentes (hipoclorito de sódio 5,25\%, hipoclorito de sódio a $2 \%$, deconex a $5 \%$ e solução de savlex a 5\%) em quatro materiais reembasadores macios (Tempo, Immediate, Flexacryl soft e Ufi Gel P) contaminados com Stafilococcus aureus, Streptococos sobrinus e Candida albicans. Segundo os autores, os materiais macios são mais suceptíveis à adesão microbiana do que as bases de próteses de resina acrílica; e como a higiene das próteses é essencial para manter a durabilidade de próteses, soluções desinfetantes foram sugeridas como um método para limpar efetivamente os materiais reembasadores resilientes. Os quatro reembasadores resilientes foram contaminados com cada um dos microorganismos, e os testes de desinfecção foram aplicados para analisar a eficácia destes higienizadores nos materiais em um teste in vitro. Os corpos-de-prova $(n=5$, total $=240)$ foram imersos por cinco minutos em cada solução para desinfecção dos microorganismos. Os corpos-de-prova do grupo controle (um de cada material; $\mathrm{n}=5$, total $=60$ ) foram imersos em água destilada por cinco minutos. Os resultados encontrados foram uma redução significante em todos os grupos testados, mas com o hipoclorito de sódio a 5,25\% apresentando a maior redução de todas. Então os autores concluíram que o hipoclorito de sódio a 5,25\% é o melhor desinfetante dos testados e que o tempo de imersão dos outros higienizadores poderia ser maior para alcançar resultados mais significativos.

Yoeli et al. (1996) estudaram a consistência e a dureza de quatro reembasadores macios (Coe Soft, Flexacryl, Lynal e Permasoft). A consistência é avaliada pelo teste de escoamento inicial. Este teste permite ao clínico selecionar o material de acordo com o tamanho e espessura do rebordo e com as condições do tecido mole. A dureza, avaliada pelo 
Shore Durômetro A, foi comparada com a dureza de dois materiais à base de silicone (Molloplast-B e Permaflex), pela sua conhecida maciez em longo prazo. Com os resultados, os autores concluíram que a consistência dos quatro reembasadores macios autopolimerizáveis, cumpriram com as especificações ISO 10139-1, com o diâmetro dos discos variando entre $41,3 \mathrm{~mm}$ a $72,2 \mathrm{~mm}$. A dureza dos quatro materiais variou com o tempo, diferentemente dos materiais à base de silicone, na qual a dureza, permaneceu estável. As leituras de dureza variaram significantemente com a espessura do corpo-de-prova e indicaram a necessidade da criação de um critério para a medida das propriedades de dureza, além da determinação de uma espessura mínima requerida para adequada performance clínica. 


\section{PROPOSIÇÃO}

O objetivo deste estudo foi avaliar a influência de uma solução efervescente (perborato de sódio) para higiene de próteses totais na sorção de água, solubilidade, alteração de cor e dureza de dois materiais reembasadores: um à base de resina acrílica (rígido) e um à base de silicone (macio). 


\section{MATERIAL E MÉTODOS}

Os materiais empregados para a realização deste estudo estão descritos na tabela 1.

Tabela 1 - Materiais avaliados.

\begin{tabular}{l|l|l}
\hline Nome Comercial & \multicolumn{1}{|c|}{ Material } & Fabricante \\
\hline Kooliner & $\begin{array}{l}\text { Polímero: polimetilmetacrilato acetato de etila } \\
\text { e álcool etílico; selante: etilcetona de metila. }\end{array}$ & $\begin{array}{l}\text { GC América Inc., } \\
\text { USA. }\end{array}$ \\
\hline Elite Soft & $\begin{array}{l}\text { Adesivo: etilacetato; Elite Soft soft: } \\
\text { polivinilsiloxano; verniz: polivinilsiloxano. }\end{array}$ & $\begin{array}{l}\text { Kettenbach, } \\
\text { Alemanha }\end{array}$ \\
\hline Corega Tabs & $\begin{array}{l}\text { Pastilha efervescente à base de perborato de } \\
\text { sódio. }\end{array}$ & $\begin{array}{l}\text { Corega, Block Drug } \\
\text { Company, Inc-USA. }\end{array}$ \\
\hline
\end{tabular}

\section{Teste de sorção de água e solubilidade}

Para os testes de sorção e solubilidade, 30 discos foram obtidos a partir de uma matriz metálica contendo cinco moldes de mesmo tamanho $(15 \mathrm{~mm}$ de diâmetro $\mathrm{X} 3 \mathrm{~mm}$ de espessura), para cada material reembasador. A matriz metálica foi posicionada sobre uma placa de vidro, fixada à mesma com fita adesiva e, de acordo com as instruções dos fabricantes de cada material, estes foram manipulados e inseridos nos moldes. O conjunto matriz metálica/reembasador foi coberto por outra placa de vidro até que o material sofresse a polimerização (Figura 1).

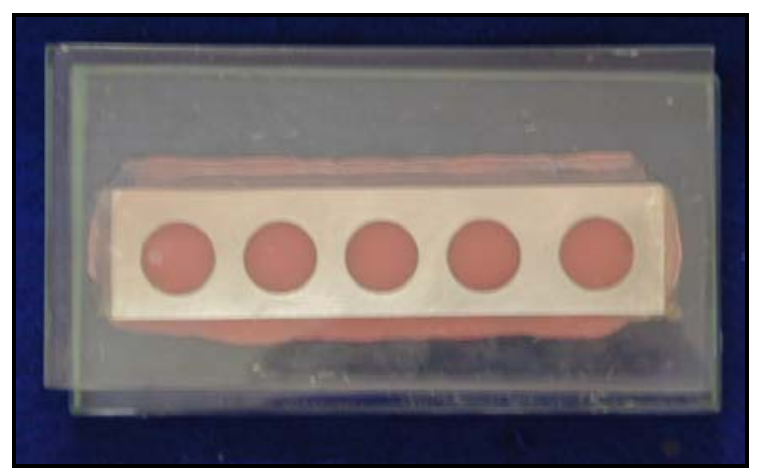

Figura 1 - Material reembasador e matriz metálica posicionados entre as duas placas de vidro. 
Em seguida, os corpos-de-prova foram removidos dos moldes e receberam o acabamento. Para o Kooliner, o acabamento foi realizado com brocas de carboneto de tungstênio número 1572 (Edenta AG, Suíça), tomando o cuidado de serem eliminadas somente as rebarbas e arestas presentes. Para o Elite Soft os excessos de foram recortados com tesoura afiada (Figuras 2 e 3 ).

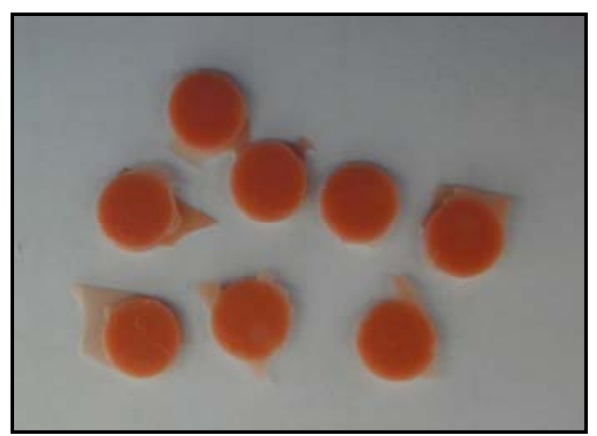

Figura 2 - Corpos-de-prova de Kooliner antes do acabamento.

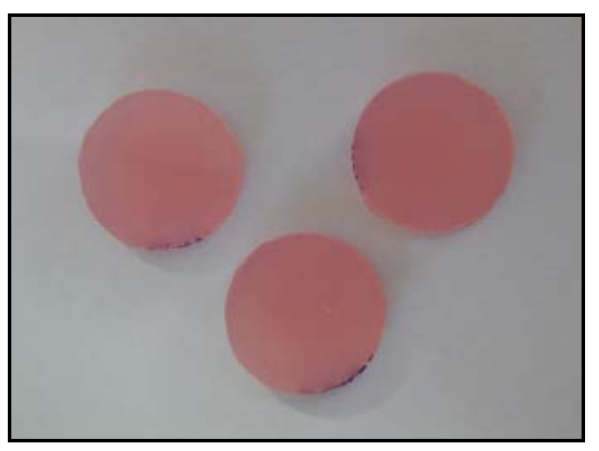

Figura 3 - Corpos-de-prova de Elite soft após recorte dos excessos.

Todos os corpos-de-prova foram pesados imediatamente após o acabamento, colocados em um dessecador contendo sílica gel azul desidratada à temperatura ambiente e pesados diariamente em balança de precisão (Metler Toledo GMbH, Laboratory \& Weighing Technologies, Greifensee, Switzerland) (Figuras 4 e 5) até a estabilidade dos pesos $( \pm 0,001 \mathrm{~g})$, obtendo-se assim, a massa inicial (M1). 


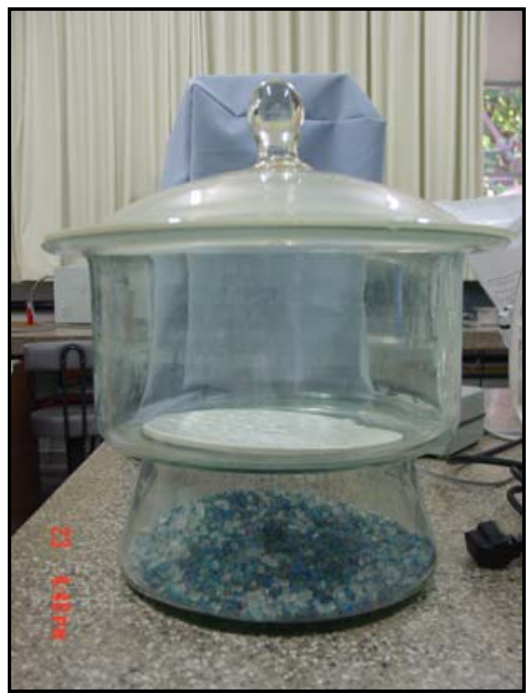

Figura 4 - Dessecador contendo sílica gel.

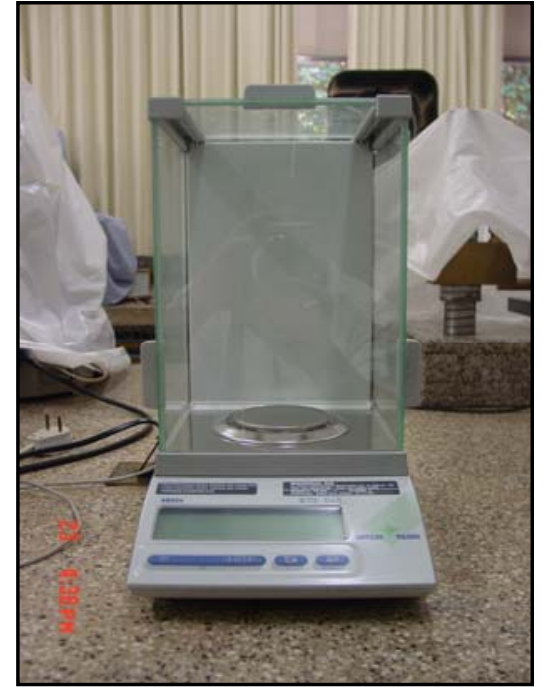

Figura 5 - Balança analítica de precisão.

Os 30 corpos-de-prova de cada material foram divididos, aleatoriamente, em 2 grupos:

G1 (controle) e G2 (experimental). O grupo G1 foi imerso em saliva artificial a $37^{\circ} \mathrm{C}$ e o grupo G2 também foi imerso nas mesmas condições, acrescentando-se, porém, imersões diárias por cinco minutos, em solução efervescente à base de perborato de sódio. Após 120 dias, todos os espécimes foram pesados novamente para a obtenção da massa final (M2). O valor da sorção foi determinado a partir da seguinte equação:

Sorção $=\frac{\mathrm{M} 1-\mathrm{M} 2}{\text { Volume }}$

O ensaio de solubilidade consistiu em analisar a perda da massa dos corpos-de-prova após o período de imersão e recondicionamento a um valor de massa constante. Este ensaio foi realizado logo após o ensaio de sorção descrito acima, de tal forma que após a obtenção de M2, os discos foram recolocados no dessecador contendo sílica gel azul desidratada, pesados diariamente até a estabilidade na leitura dos pesos $( \pm 0,001 \mathrm{~g})$, obtendo-se assim, a massa final para solubilidade (M3). O valor da solubilidade foi calculado conforme a seguinte equação: 


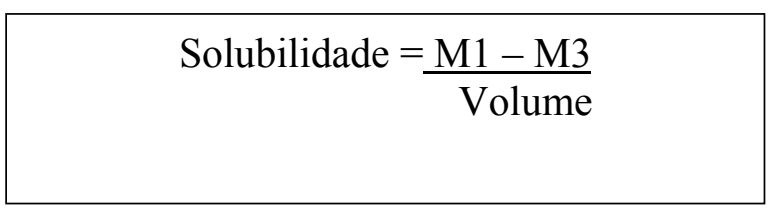

\section{Teste de alteração de cor}

Os mesmos corpos-de-prova utilizados para análise da sorção de água e solubilidade foram usados para avaliar a alteração de cor. A mensuração da cor foi obtida logo após a confecção dos corpos-de-prova e após 30 e 120 dias de imersão.

A alteração de cor $(\Delta \mathrm{E})$ foi determinada com o auxílio do espectrocolorímetro portátil modelo Color Guide 45/0 (BYK-Gardner GmbH - 07/2002, Geretsried, Alemanha) (Figura 6), utilizando o sistema de cores Standard Commission Internationale de L'Eclairage (CIE LAB), recomendado pela American Dental Association. Este sistema representa um espaço tridimensional de cor tendo componentes de clareza (L), vermelho-verde (a), e amarelo-azul (b). Um aspecto importante do sistema CIE-LAB é que a diferença de cor entre os tempos pode ser dada usando um parâmetro, $\triangle \mathrm{Eab}$. A alteração de cor entre cada corpo-de-prova, cada uma dada em termos de L, a e b, foi calculada pela seguinte fórmula:

$\Delta \mathrm{Eab}=\left[(\Delta \mathrm{L})^{2}+(\Delta \mathrm{a})^{2}+(\Delta \mathrm{b})^{2}\right]^{1 / 2}$

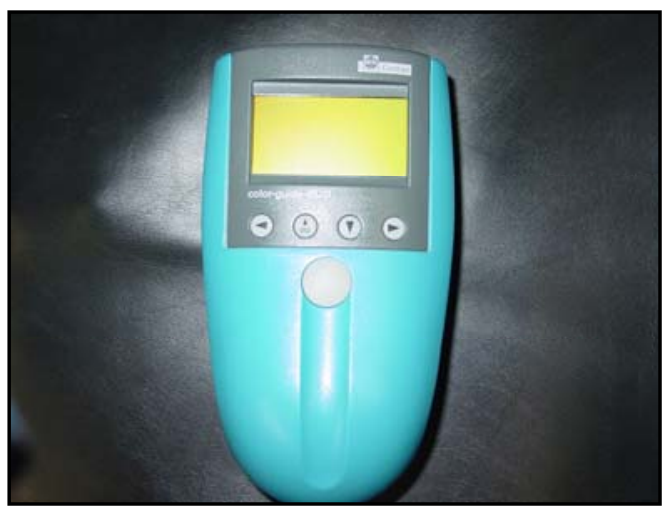

Figura 6 - Espectrocolorímetro portátil Modelo Color Guide. 


\section{Teste de dureza}

Para o teste de dureza, 30 discos de cada material foram obtidos a partir de uma matriz metálica contendo cinco moldes de mesmo tamanho $(15 \mathrm{~mm}$ de diâmetro $\mathrm{X} 3 \mathrm{~mm}$ de espessura), para cada material reembasador. A matriz metálica foi posicionada sobre uma placa de vidro, fixada à mesma com fita adesiva, e de acordo com as instruções dos fabricantes de cada material, estes foram manipulados e inseridos nos moldes. O conjunto matriz metálica/reembasador foi coberto por outra placa de vidro até a presa do material. Posteriormente, os materiais foram removidos dos moldes para receberem o acabamento. Para o Kooliner, o acabamento foi realizado com brocas de carboneto de tungstênio número 1572 (Edenta AG, Suíça), tomando o cuidado de serem eliminadas somente as rebarbas e arestas presentes. Para o Elite Soft, os excessos de foram recortados com tesoura afiada.

Os 30 corpos-de-prova de cada material foram divididos nos 2 grupos G1 (controle: imersão em saliva artificial a $37^{\circ} \mathrm{C}$ e $\mathrm{G} 2$ (experimental: imersão em saliva artificial a $37^{\circ} \mathrm{C}$ associada à imersões diárias por cinco minutos, em solução efervescente à base de perborato de sódio) .

O teste de dureza foi realizado imediatamente após o acabamento (T0) e após 30 (T30) e 60 (T60) dias de imersão. Antes da leitura de dureza, a superfície do corpo-de-prova foi levemente seca com papel absorvente e os valores de dureza foram registrados da seguinte maneira:

1. Kooliner: "Microhardness Tester Shimadzeu", com uma carga de 25g por 5 segundos (Figura 7); 


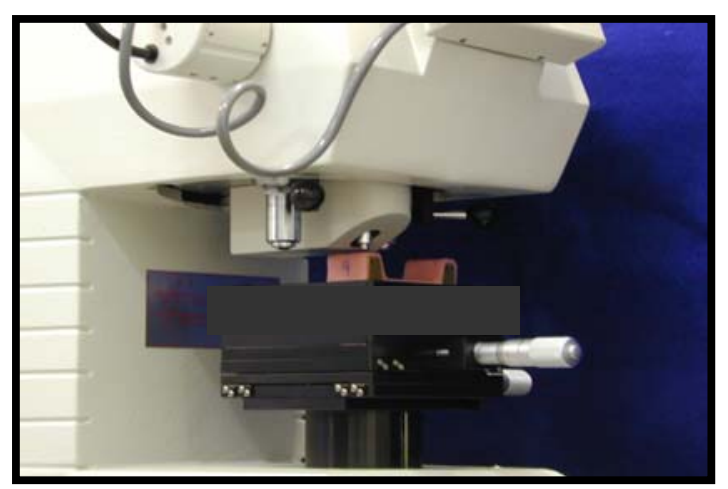

Figura 7 - Corpo-de-prova posicionado para mensuração da dureza do Kooliner.

2. Elite Soft: "Shore A Durometer" (Instrument and Manufacturing Co Inc, Frieport, N.Y.) com os corpos-de-prova posicionados sob a haste vertical do mesmo e submetidos à força de $1 \mathrm{Kg}$ (ASTM 2240-64T) (Figura 8).

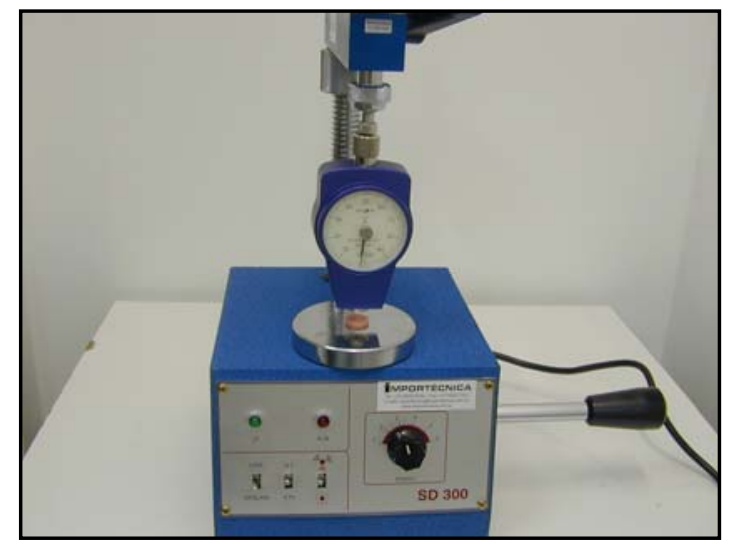

Figura 8 - Corpo-de-prova posicionado para mensuração da dureza do Elite soft.

Para os dois materiais, foram realizadas 3 leituras em cada corpo-de-prova para cada período de tempo (T0, T30 e T60). 


\section{Análise dos resultados}

Realizados todos os ensaios, os dados foram submetidos a testes estatísticos de normalidade e homogeneidade, para então ser definido o modelo estatístico a ser utilizado. Para o conjunto de dados com distribuição normal e homogênea, empregou-se estatística paramétrica e para os dados com distribuição não-normal, foi utilizada estatística não-paramétrica.

Para análise dos dados de sorção, foi empregado o Teste de Kruskal-Wallis $(\mathrm{P}<0,05)$ a dois fatores de variação, sem vinculação. Para os dados de solubilidade, foi aplicado o Teste Anova a dois fatores, amostras independentes com repetições $(\mathrm{P}<0,05)$. Para a análise de cor, utilizou-se o teste ANOVA com três fatores de variação, sendo um deles (tempo) vinculado. Para comparação das médias, aplicou-se o Teste Complementar de Tukey $(\mathrm{P}<0,05)$. Além dessa análise, a observação crítica da alteração de cor foi quantificada também pelo National Bureau of Standards (NBS) com unidades NBS de alteração de cor (Tabela 2). As unidades NBS são expressas pela seguinte fórmula: unidades NBS $=\Delta E^{\star} a b X$ 0,92.

Tabela 2 - Unidades NBS.

\begin{tabular}{ll}
\hline Observação crítica de alteração de cor & Unidades NBS \\
Muito Leve & $0,0-0,5$ \\
Leve & $0,5-1,5$ \\
Notável & $1,5-3,0$ \\
Apreciável & $3,0-6,0$ \\
Alta & $6,0-12,0$ \\
Muito Alta & $>12,0$
\end{tabular}

A análise dos dados de dureza do Kooliner e do Elite soft foi realizada por meio do Teste ANOVA $(\mathrm{P}<0,05)$ a dois fatores de variação (grupo e tempo, sendo este vinculado) seguido do Teste de Tukey $(\mathrm{P}<0,05)$. 


\section{RESULTADOS}

\section{Teste de sorção}

Na tabela 3 estão apresentados os pesos dos corpos-de-prova obtidos após a dessecagem e após 120 dias de imersão nos grupos controle e experimental. 
Tabela 3 - Pesos dos corpos-de-prova após o dessecamento (PD) e $120\left(\mathrm{M}_{2}\right)$ dias de imersão nos grupos controle e experimental.

\begin{tabular}{|c|c|c|c|c|}
\hline \multirow[t]{2}{*}{ Materiais } & \multicolumn{2}{|c|}{ Grupo Controle } & \multicolumn{2}{|c|}{ Grupo Experimental } \\
\hline & $\mathbf{P D}\left(\mathrm{M}_{1}\right)$ & T120 $\left(M_{2}\right)$ & $\mathbf{P D}\left(\mathrm{M}_{1}\right)$ & $\mathrm{T} 120\left(\mathrm{M}_{2}\right)$ \\
\hline \multirow{15}{*}{ Kooliner } & 0,888 & 0,894 & 0,910 & 0,916 \\
\hline & 0,919 & 0,927 & 0,910 & 0,920 \\
\hline & 0,900 & 0,908 & 0,887 & 0,895 \\
\hline & 0,907 & 0,914 & 0,897 & 0,903 \\
\hline & 0,887 & 0,895 & 0,906 & 0,912 \\
\hline & 0,894 & 0,901 & 0,920 & 0,930 \\
\hline & 0,918 & 0,926 & 0,920 & 0,928 \\
\hline & 0,900 & 0,907 & 0,878 & 0,894 \\
\hline & 0,912 & 0,919 & 0,913 & 0,921 \\
\hline & 0,825 & 0,832 & 0,925 & 0,933 \\
\hline & 0,910 & 0,916 & 0,929 & 0,937 \\
\hline & 0,920 & 0,927 & 0,896 & 0,903 \\
\hline & 0,897 & 0,903 & 0,888 & 0,895 \\
\hline & 0,913 & 0,920 & 0,917 & 0,923 \\
\hline & 0,858 & 0,865 & 0,916 & 0,923 \\
\hline Médias & 0,896 & 0,903 & 0,907 & 0,915 \\
\hline \multirow{15}{*}{ Elite } & 1,096 & 1,098 & 1,062 & 1,064 \\
\hline & 1,079 & 1,080 & 0,979 & 0,984 \\
\hline & 1,029 & 1,031 & 0,971 & 0,973 \\
\hline & 1,031 & 1,032 & 1,053 & 1,056 \\
\hline & 1,023 & 1,024 & 0,999 & 1,002 \\
\hline & 1,019 & 1,021 & 1,016 & 1,019 \\
\hline & 1,027 & 1,029 & 1,024 & 1,027 \\
\hline & 1,037 & 1,038 & 1,110 & 1,112 \\
\hline & 1,039 & 1,041 & 1,033 & 1,035 \\
\hline & 1,048 & 1,049 & 1,008 & 1,010 \\
\hline & 0,966 & 0,967 & 0,937 & 0,940 \\
\hline & 1,100 & 1,102 & 1,069 & 1,071 \\
\hline & 1,033 & 1,034 & 1,044 & 1,047 \\
\hline & 1,073 & 1,075 & 0,992 & 0,994 \\
\hline & 1,082 & 1,083 & 1,100 & 1,101 \\
\hline Médias & 1,045 & 1,046 & 1,026 & 1,029 \\
\hline
\end{tabular}


Na tabela 4, encontram-se os resultados obtidos para sorção, após a aplicação da fórmula

$$
\text { Sorção }=\frac{\text { M1 (PD) }- \text { M2 (T120) }}{\text { Volume }}
$$

sobre os valores de PD e T120 da Tabela 3.

Tabela 4 - Sorção sofrida pelos corpos-de-prova de Kooliner e Elite Soft após 120 dias de

\begin{tabular}{|c|c|c|c|c|}
\hline \multirow[t]{2}{*}{$\mathbf{N}$} & \multicolumn{2}{|c|}{ Kooliner } & \multicolumn{2}{|c|}{ Elite Soft } \\
\hline & Controle & Experimental & Controle & Experimental \\
\hline 1 & 0,322 & 0,322 & 0,107 & 0,107 \\
\hline 2 & 0,430 & 0,537 & 0,054 & 0,269 \\
\hline 3 & 0,430 & 0,430 & 0,107 & 0,107 \\
\hline 4 & 0,376 & 0,322 & 0,054 & 0,161 \\
\hline 5 & 0,430 & 0,322 & 0,054 & 0,161 \\
\hline 6 & 0,376 & 0,537 & 0,107 & 0,161 \\
\hline 7 & 0,430 & 0,430 & 0,107 & 0,161 \\
\hline 8 & 0,376 & 0,860 & 0,054 & 0,107 \\
\hline 9 & 0,376 & 0,430 & 0,107 & 0,107 \\
\hline 10 & 0,376 & 0,430 & 0,054 & 0,107 \\
\hline 11 & 0,322 & 0,430 & 0,054 & 0,161 \\
\hline 12 & 0,376 & 0,376 & 0,107 & 0,107 \\
\hline 13 & 0,322 & 0,376 & 0,054 & 0,161 \\
\hline 14 & 0,376 & 0,322 & 0,107 & 0,107 \\
\hline 15 & 0,376 & 0,376 & 0,054 & 0,054 \\
\hline Médias & 0,376 & 0,430 & 0,054 & 0,161 \\
\hline DP & 0,038 & 0,137 & 0,027 & 0,049 \\
\hline
\end{tabular}
imersão nos grupos controle e experimental.

Após análise dos dados, foi verificada a distribuição não-normal (Apêndice A, Tabela A1), optando-se assim, pela aplicação do Teste de Kruskal Wallis (não paramétrico a dois fatores sem pareamento) (Tabela 5).

Tabela 5 - Teste de Kruskal Wallis para os dados da sorção sofrida pelos corpos-de-prova de Kooliner e Elite soft após imersão nos grupos controle e experimental.

Valor (H) de Kruskal-Wallis calculado 48,4729

Valor do X para 3 graus de liberdade 
Na tabela 6, encontra-se a comparação entre as médias dos postos das amostras nos grupos controle (G1: imersão em saliva artificial a $37^{\circ} \mathrm{C}$ ) e experimental (G2: imersão em saliva artificial a $37^{\circ} \mathrm{C}$ com imersões diárias em perborato de sódio).

Tabela 6 - Comparação entre as médias dos postos das amostras.

\begin{tabular}{l|c|rcc|c}
\hline Amostras comparadas & Diferenças & \multicolumn{3}{|c|}{ Valores críticos } & Significância \\
(comparações duas a duas) & entre médias & $\mathbf{0 , 0 5}$ & $\mathbf{0 , 0 1}$ & $\mathbf{0 , 0 0 1}$ & \\
\hline Kooliner G1 X Elite G1 & 33,5000 & 5,4633 & 7,2750 & 9,4814 & $0,1 \%$ \\
Kooliner G1 X Kooliner G2 & 3,2667 & 5,4633 & 7,2750 & 9,4814 & ns \\
Elite G1 X Elite G2 & 10,2667 & 5,4633 & 7,2750 & 9,4814 & $0,1 \%$ \\
Kooliner G2 X Elite G2 & 26,5000 & 5,4633 & 7,2750 & 9,4814 & $0,1 \%$ \\
\hline
\end{tabular}

No gráfico 1 encontra-se a comparação das médias de sorção dos corpos-de-prova de Kooliner e Elite soft dos grupos controle e experimental, com diferença estatística relevante.

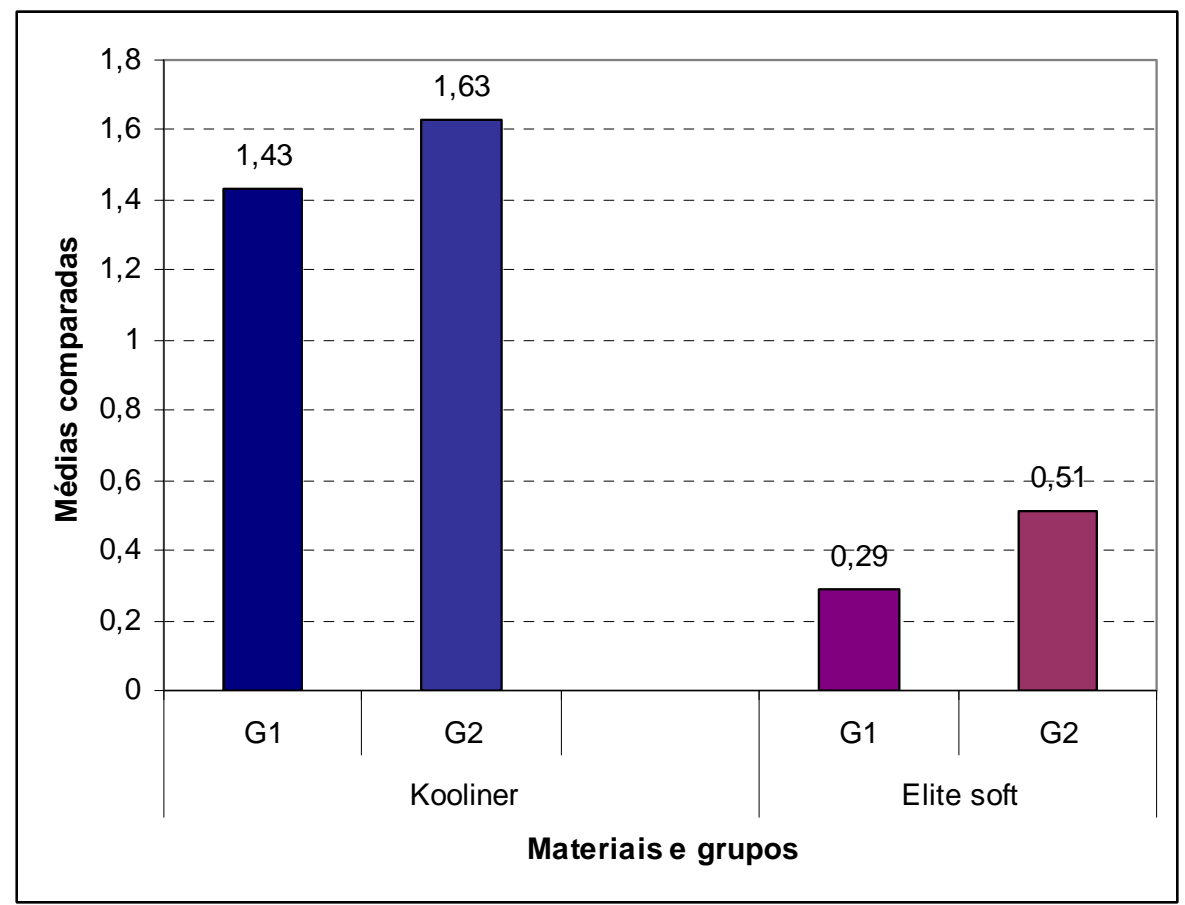

Gráfico 1 - Comparação das médias de sorção dos corpos-de-prova de Kooliner e Elite soft nos grupos controle (G1) e experimental (G2).

*Colunas interligadas = igualdade estatística. 
Para o material Kooliner, o tipo de imersão (saliva artificial - G1 e saliva artificial associada ao perborato de sódio- G2) não interferiu nos valores de sorção. Quanto ao Elite soft, o perborato de sódio 2 promoveu aumento significativo nos valores de sorção. Comparando os materiais, o Kooliner apresentou médias de sorção significativamente mais altas que o Elite soft, para os dois grupos estudados.

\section{Teste de solubilidade}

Na tabela 7, encontram-se os pesos dos corpos-de-prova para o cálculo da solubilidade sofrida pelos materiais Kooliner e Elite Soft após 120 dias de imersão nos grupos controle e experimental. 
Tabela 7 - Pesos M1 e M3 dos corpos-de-prova para controle e experimental.

\begin{tabular}{|c|c|c|c|c|}
\hline \multirow[t]{2}{*}{ Materiais } & \multicolumn{2}{|c|}{ Grupo controle } & \multicolumn{2}{|c|}{ Grupo Experimental } \\
\hline & M1 & M3 & M1 & M3 \\
\hline \multirow{15}{*}{ Kooliner } & 0,888 & 0,884 & 0,910 & 0,906 \\
\hline & 0,919 & 0,917 & 0,910 & 0,906 \\
\hline & 0,900 & 0,897 & 0,887 & 0,884 \\
\hline & 0,907 & 0,903 & 0,897 & 0,894 \\
\hline & 0,887 & 0,884 & 0,906 & 0,903 \\
\hline & 0,894 & 0,891 & 0,920 & 0,917 \\
\hline & 0,918 & 0,916 & 0,920 & 0,918 \\
\hline & 0,900 & 0,897 & 0,878 & 0,875 \\
\hline & 0,912 & 0,909 & 0,913 & 0,911 \\
\hline & 0,825 & 0,820 & 0,925 & 0,923 \\
\hline & 0,910 & 0,906 & 0,929 & 0,927 \\
\hline & 0,920 & 0,917 & 0,896 & 0,893 \\
\hline & 0,897 & 0,893 & 0,888 & 0,886 \\
\hline & 0,913 & 0,910 & 0,917 & 0,914 \\
\hline & 0,858 & 0,852 & 0,916 & 0,913 \\
\hline Médias & 0,896 & 0,893 & 0,907 & 0,904 \\
\hline \multirow{15}{*}{ Elite soft } & 1,096 & 1,095 & 1,062 & 1,060 \\
\hline & 1,079 & 1,077 & 0,979 & 0,978 \\
\hline & 1,029 & 1,029 & 0,971 & 0,969 \\
\hline & 1,031 & 1,028 & 1,053 & 1,052 \\
\hline & 1,023 & 1,021 & 0,999 & 0,998 \\
\hline & 1,019 & 1,017 & 1,016 & 1,016 \\
\hline & 1,027 & 1,026 & 1,024 & 1,023 \\
\hline & 1,037 & 1,035 & 1,110 & 1,108 \\
\hline & 1,039 & 1,037 & 1,033 & 1,031 \\
\hline & 1,048 & 1,046 & 1,008 & 1,006 \\
\hline & 0,966 & 0,964 & 0,937 & 0,936 \\
\hline & 1,100 & 1,098 & 1,069 & 1,068 \\
\hline & 1,033 & 1,031 & 1,044 & 1,043 \\
\hline & 1,073 & 1,072 & 0,992 & 0,991 \\
\hline & 1,082 & 1,081 & 1,100 & 1,098 \\
\hline Médias & 1,045 & 1,043 & 1,026 & 1,025 \\
\hline
\end{tabular}


Na tabela 8 encontram-se os resultados para o teste de solubilidade após a aplicação da fórmula $\quad$ Solubilidade $=\frac{\mathrm{M} 1-\mathrm{M} 3}{\text { Volume }}$ sobre os dados da tabela acima.

Tabela 8 - Solubilidade sofrida pelos corpos-de-prova de Kooliner e Elite Soft após 120 dias de imersão nos grupos controle e experimental.

\begin{tabular}{cccccc}
\hline \multirow{2}{*}{$\mathbf{N}$} & \multicolumn{2}{c}{ Kooliner } & & \multicolumn{2}{c}{ Elite Soft } \\
\cline { 2 - 3 } \cline { 5 - 6 } \cline { 5 - 6 } & Controle & Experimental & & Controle & Experimental \\
\hline $\mathbf{1}$ & 0,215 & 0,215 & & 0,054 & 0,107 \\
$\mathbf{2}$ & 0,107 & 0,215 & & 0,107 & 0,054 \\
$\mathbf{3}$ & 0,161 & 0,161 & & 0,000 & 0,107 \\
$\mathbf{4}$ & 0,215 & 0,161 & & 0,161 & 0,054 \\
$\mathbf{5}$ & 0,161 & 0,161 & & 0,107 & 0,054 \\
$\mathbf{6}$ & 0,161 & 0,161 & & 0,107 & 0,000 \\
$\mathbf{7}$ & 0,107 & 0,107 & & 0,054 & 0,054 \\
$\mathbf{8}$ & 0,161 & 0,161 & & 0,107 & 0,107 \\
$\mathbf{9}$ & 0,161 & 0,107 & & 0,107 & 0,107 \\
$\mathbf{1 0}$ & 0,269 & 0,107 & & 0,107 & 0,107 \\
$\mathbf{1 1}$ & 0,215 & 0,107 & & 0,107 & 0,054 \\
$\mathbf{1 2}$ & 0,161 & 0,161 & & 0,107 & 0,054 \\
$\mathbf{1 3}$ & 0,215 & 0,107 & & 0,107 & 0,054 \\
$\mathbf{1 4}$ & 0,161 & 0,161 & & 0,054 & 0,054 \\
$\mathbf{1 5}$ & 0,322 & 0,161 & & 0,054 & 0,107 \\
\hline Médias & $\mathbf{0 , 1 6 1}$ & $\mathbf{0 , 1 6 1}$ & & $\mathbf{0 , 1 0 7}$ & $\mathbf{0 , 0 5 4}$ \\
\hline $\mathbf{D P}$ & $\mathbf{0 , 0 5 7}$ & $\mathbf{0 , 0 3 7}$ & & $\mathbf{0 , 0 3 9}$ & $\mathbf{0 , 0 3 3}$ \\
\hline
\end{tabular}

Para avaliação dos dados da tabela 8 , foi empregado o teste Anova $(\mathrm{P}<0,05)$ a dois fatores de variação (Tabela 9), uma vez que a distribuição dos dados apresentou-se normal e homogênea (Apêndice B, Tabela B1). Houve diferença significante entre o fator grupo e entre o fator material. O Kooliner bem como o grupo 1 apresentaram as maiores médias de solubilidade em relação ao Elite soft e o grupo 2, respectivamente. 
Tabela 9 - Teste Anova dos dados de solubilidade dos corpos-de-prova de Kooliner e Elite soft após imersão nos grupos controle e experimental

\begin{tabular}{llllll}
\hline Fonte de Variação & Soma de Quadr. & G.L. & Quadr.Médios & ( F ) & Prob.(H0) \\
\hline Grupo (G) & 0.0108 & 1 & 0.0108 & 6.03 & $1.632 \%$ \\
Material (M) & 0.1154 & 1 & 0.1154 & 64.41 & $0.000 \%$ \\
G x M & 0.0012 & 1 & 0.0012 & 0.69 & $41.365 \%$ \\
Resíduo & 0.1003 & 56 & 0.0018 & & \\
Variação total & 0.2277 & 59 & & & \\
\hline
\end{tabular}

No gráfico 2, encontra-se a comparação entre as médias dos materiais e dos grupos controle (G1: imersão em saliva artificial a $\left.37^{\circ} \mathrm{C}\right)$ e experimental (G2: imersão em saliva artificial a $37^{\circ} \mathrm{C}$ com imersões diárias em perborato de sódio).

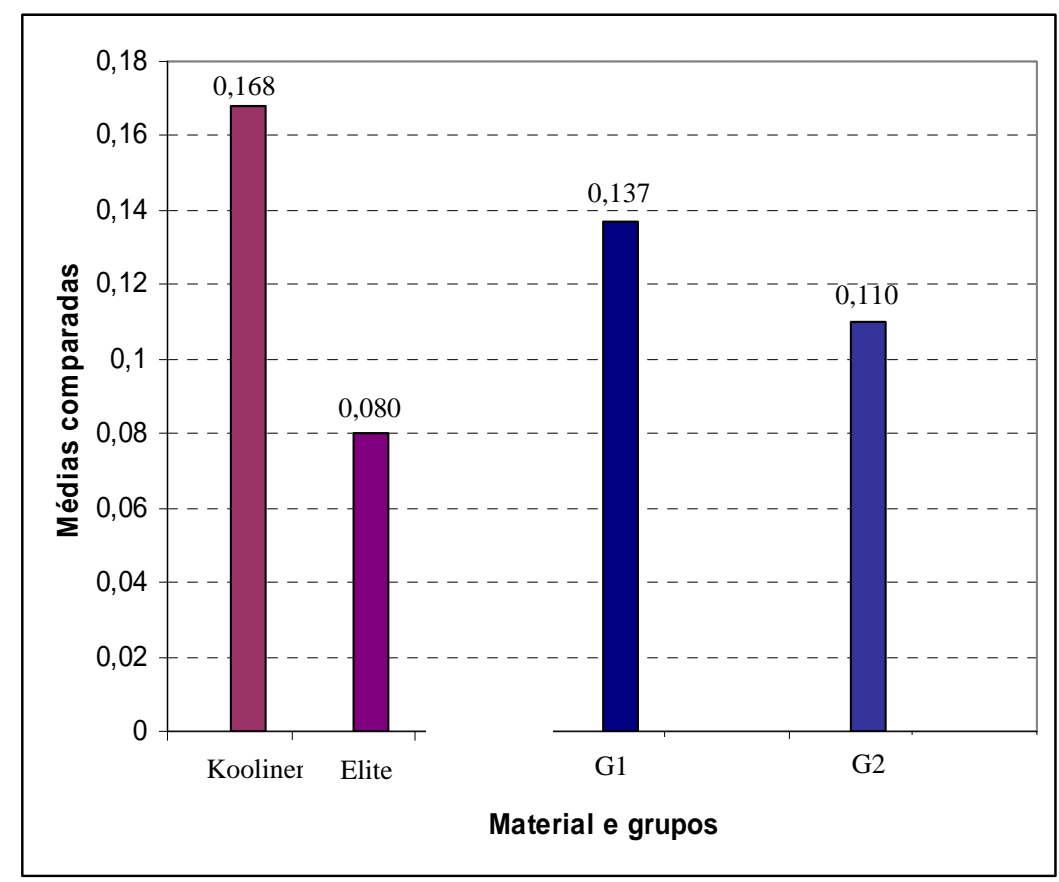

Gráfico 2 - Comparação entre as médias de solubilidade dos corpos-de-prova de Kooliner e Elite soft e dos grupos controle e experimental.

\section{Teste de alteração de cor}

Os dados da variação de cor sofrida pelos materiais Kooliner e Elite soft após 30 e 120 dias de imersão nos grupos controle (G1) e experimental G2) estão apresentados na tabela 10. 
Tabela 10 - Variação de cor sofrida pelos materiais avaliados após 30 e 120 dias de imersão nos grupos controle e experimental.

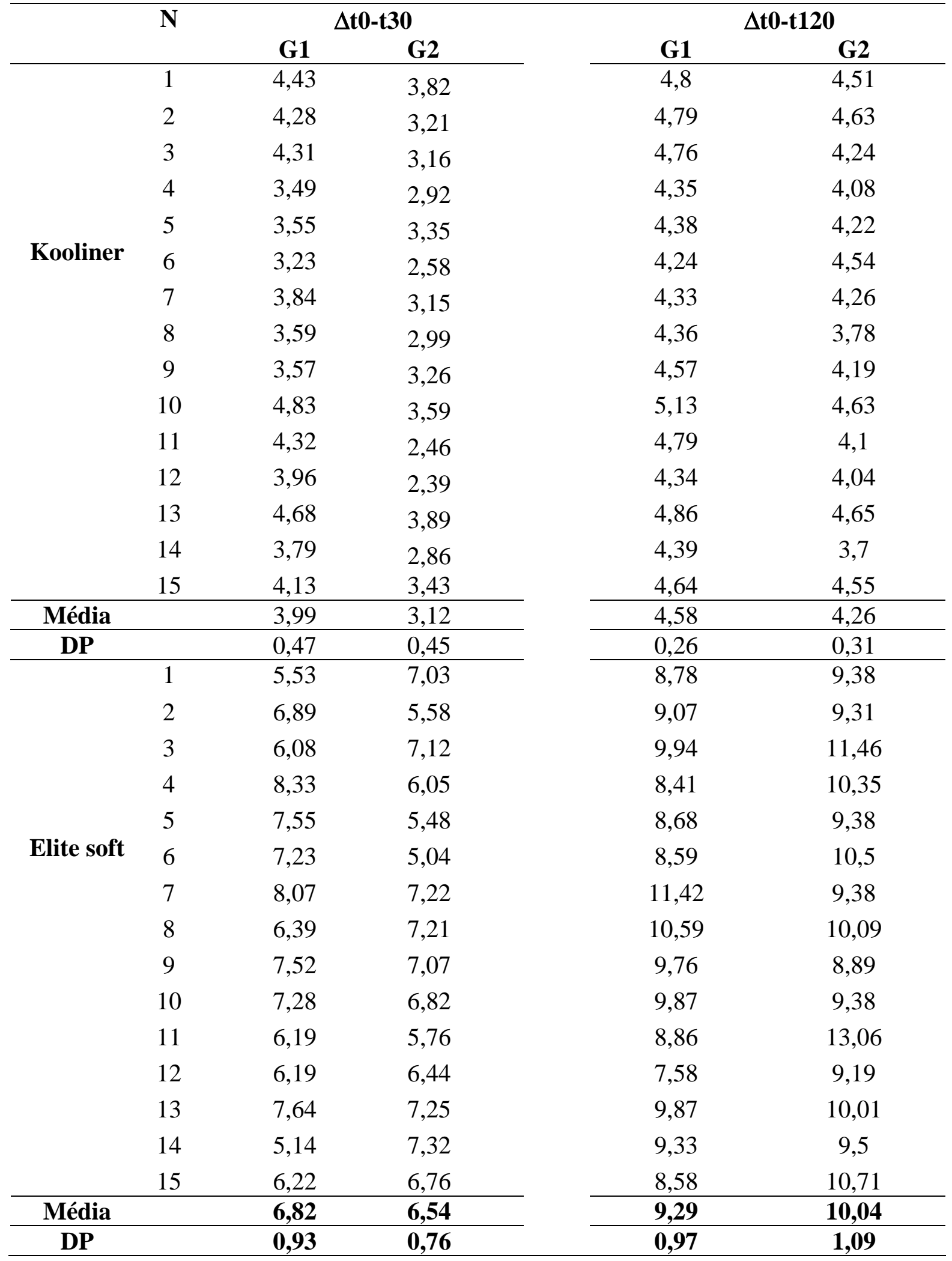


Após a avaliação dos dados quanto ä distribuição e homogeneidade, aplicou-se o teste Anova (Tabela 11) a três fatores: material, grupo e tempo, sendo este vinculado.

Tabela 11 - Análise de variância dos dados da variação de cor.

\begin{tabular}{lccccc}
\hline Fonte de variação & Soma de Quadr. & G.L. & Quadr.Médios & ( F ) & Prob.(H0) \\
\hline Grupos (G) & 0.8975 & 1 & 0.8975 & 156 & $21.3894 \%$ \\
Material (M) & 522.4569 & 1 & 522.4569 & 910.36 & $0.0000 \%$ \\
G x M & 5.0988 & 1 & 5.0988 & 8.88 & $0.4486 \%$ \\
Resíduo I & 32.1385 & 56 & 0.5739 & & \\
Tempo (T) & 110.8007 & 1 & 110.8007 & 236.80 & $0.0000 \%$ \\
T x G & 4.6790 & 1 & 4.6790 & 10.00 & $0.2868 \%$ \\
T x M & 33.8702 & 1 & 33.8702 & 72.39 & $0.0000 \%$ \\
T x G x M & 0.4069 & 1 & 0.4069 & 0.87 & $35.7618 \%$ \\
Resíduo II & 26.2032 & 56 & 0.4679 & & \\
Variação total & 736.5518 & 119 & & & \\
\hline
\end{tabular}

Analisando a tabela acima, pôde-se verificar a existência de diferença significante entre os fatores material (Kooliner: $\mu=4,0, \mathrm{DP}=0,63$; Elite soft: $\mu=8,17, \mathrm{DP}=1,75$ ) e tempo ( $\Delta \mathrm{t} 0$-t30: $\mu=5,12, \mathrm{DP}=1,84 ; \Delta \mathrm{t} 0$-t120: $\mu=7,04, \mathrm{DP}=3,05)$. Houve interação entre os fatores grupo x material, tempo x grupo e tempo x material. Para a comparação das médias, foi aplicado o Teste de Tukey $(\mathrm{P}<0,05)$ (Tabelas 12, 13, 14).

Tabela 12 - Comparação das médias (Desvio-padrão) da interação grupo x material.

\begin{tabular}{lccc}
\hline & $\begin{array}{c}\text { Grupo } \\
\text { controle }\end{array}$ & Grupo Experimental & Valor de Tukey \\
\hline Kooliner & $4,29(0,48){ }^{\mathrm{Aa}}$ & $3,70(0,69)^{\mathrm{Aa}}$ & 0,59 \\
Elite soft & $8,05(1,57)^{\mathrm{Ab}}$ & $8,29(2,0)$ & \\
\hline
\end{tabular}

Letras maiúsculas: comparação entre colunas; Letras minúsculas comparação entre linhas. Letras diferentes indicam diferença estatística.

Tabela 13 - Comparação das médias (Desvio-padrão) da interação tempo x grupo.

\begin{tabular}{cccc}
\hline & Grupo controle & Grupo Experimental & Valor de Tukey \\
\hline$\Delta \mathbf{t 0}-\mathbf{t} 30$ & $5,40(1,61)^{\mathrm{Aa}}$ & $4,84(1,84)^{\mathrm{Aa}}$ & 0,52 \\
$\Delta \mathbf{t 0 - t 1 2 0}$ & $6,93(2,49)^{\mathrm{Ab}}$ & $7,15(3,03){ }^{\mathrm{Ab}}$ & \\
\hline
\end{tabular}

Letras maiúsculas: comparação entre colunas; Letras minúsculas comparação entre linhas. Letras diferentes indicam diferença estatística. 
Tabela 14 - Comparação das médias (Desvio-padrão) da interação tempo x material.

\begin{tabular}{lllc}
\hline & Kooliner & Elite soft & Valor de Tukey \\
\hline$\Delta \mathbf{t 0}-\mathbf{t 3 0}$ & $3,56(0,63)^{\mathrm{Aa}}$ & $6,67(0,85))^{\mathrm{Ba}}$ & 0,52 \\
$\Delta \mathbf{t 0 - t 1 2 0}$ & $4,42(0,32)^{\mathrm{Ab}}$ & $9,66(1,08){ }^{\mathrm{Bb}}$ & \\
\hline
\end{tabular}

Letras maiúsculas: comparação entre colunas; Letras minúsculas comparação entre linhas. Letras diferentes indicam diferença estatística.

Por meio da observação crítica da alteração de cor pelo National Bureau of Standards (NBS), pode-se atribuir a classificação apresentada na tabela 15.

Tabela 15 - Avaliação da alteração de cor dos materiais após imersão nos grupos controle (G1) e experimental (G2) nos intervalos de 30 e 120 dias, segundo a classificação da NBS.

\begin{tabular}{cccccc} 
& \multicolumn{2}{c}{$\Delta$ Et0-t30 } & & \multicolumn{2}{c}{$\Delta$ Et0-t120 } \\
\cline { 2 - 3 } \cline { 5 - 6 } \cline { 5 - 6 } \cline { 5 - 6 } & $\mathbf{G 1}$ & $\mathbf{G 2}$ & & G1 & G2 \\
\hline Kooliner & $3,67^{*}$ & $2,87^{*} \#$ & & $4,21^{*}$ & $3,94^{*}$ \\
Elite soft & $6,27^{\circ}$ & $6,01^{\circ}$ & & $8,54^{\circ}$ & $9,23^{\circ}$ \\
\hline
\end{tabular}

\# Notável; * Apreciável; Alta

\section{Teste de dureza}

Na tabela 16 estão apresentados os valores referentes ao teste de dureza realizado com os corpos-de-prova de Kooliner, imediatamente a sua obtenção (T0) e após 30 (T30) e 60 (T60) dias dos mesmos terem sido submetidos à imersão em saliva artificial a $37^{\circ} \mathrm{C}$ (grupo controle - G1) e à imersão em saliva artificial a $37^{\circ} \mathrm{C}$ associada a imersões diárias em perborato de sódio por 5 minutos (grupo experimental - G2), e na tabela 17, as médias das três medidas obtidas em cada um dos tempos. 
Tabela 16 - Resultados do teste de dureza realizado com os corpos-de-prova de Kooliner em T0, T30 e T60, para os grupos controle e experimental.

\begin{tabular}{|c|c|c|c|c|c|c|c|c|c|c|}
\hline \multirow{2}{*}{ Grupos } & \multirow[b]{2}{*}{$\mathbf{N}$} & \multicolumn{9}{|c|}{ Tempo } \\
\hline & & \multicolumn{3}{|c|}{ T0 } & \multicolumn{3}{|c|}{ T30 } & \multicolumn{3}{|c|}{ T60 } \\
\hline \multirow{15}{*}{ Controle } & 1 & 2,59 & 2,78 & 2,56 & 5,65 & 6,19 & 5,22 & 5,82 & 7,97 & 5,87 \\
\hline & 2 & 7,52 & 5,76 & 7,18 & 8,86 & 7,89 & 9,24 & 9,16 & 9,59 & 9,92 \\
\hline & 3 & 2,47 & 2,65 & 4,91 & 4,56 & 4,99 & 6,95 & 6,83 & 8,26 & 8,41 \\
\hline & 4 & 3,66 & 3,29 & 2,64 & 3,50 & 5,38 & 4,55 & 5,96 & 3,58 & 6,10 \\
\hline & 5 & 4,08 & 7,59 & 8,74 & 5,63 & 6,98 & 7,60 & 7,88 & 9,59 & 9,72 \\
\hline & 6 & 2,65 & 3,52 & 2,93 & 4,94 & 6,77 & 5,77 & 6,84 & 6,97 & 5,71 \\
\hline & 7 & 5,60 & 6,70 & 5,23 & 8,40 & 7,10 & 9,87 & 8,73 & 8,25 & 11,1 \\
\hline & 8 & 8,10 & 5,67 & 8,28 & 7,30 & 8,11 & 8,86 & 8,40 & 8,74 & 9,58 \\
\hline & 9 & 5,99 & 5,31 & 3,72 & 6,83 & 6,45 & 5,78 & 8,68 & 9,19 & 9,22 \\
\hline & 10 & 5,53 & 8,09 & 8,32 & 6,77 & 8,71 & 8,93 & 7,96 & 9,02 & 9,17 \\
\hline & 11 & 8,31 & 8,17 & 9,23 & 8,44 & 7,88 & 8,37 & 10,5 & 8,09 & 8,98 \\
\hline & 12 & 3,06 & 4,35 & 3,24 & 6,84 & 7,40 & 6,79 & 5,86 & 5,63 & 6,83 \\
\hline & 13 & 7,09 & 6,29 & 5,02 & 6,89 & 5,87 & 8,76 & 8,48 & 6,46 & 7,30 \\
\hline & 14 & 5,20 & 5,02 & 5,03 & 6,15 & 6,25 & 7,25 & 6,40 & 7,48 & 6,44 \\
\hline & 15 & 10,3 & 8,83 & 9,44 & 10,1 & 8,95 & 8,90 & 9,10 & 8,33 & 10,8 \\
\hline \multirow{15}{*}{ Experimental } & 1 & 7,38 & 6,59 & 6,80 & 7,85 & 9,03 & 9,09 & 9,82 & 9,49 & 9,81 \\
\hline & 2 & 2,31 & 1,00 & 1,84 & 4,42 & 6,65 & 5,75 & 6,73 & 6,18 & 6,35 \\
\hline & 3 & 9,13 & 8,61 & 9,36 & 6,20 & 8,36 & 6,23 & 11,1 & 10,9 & 9,16 \\
\hline & 4 & 2,73 & 1,32 & 1,64 & 3,81 & 5,31 & 5,58 & 6,01 & 5,38 & 6,46 \\
\hline & 5 & 5,69 & 6,38 & 6,18 & 8,32 & 8,58 & 7,59 & 10,8 & 8,39 & 9,58 \\
\hline & 6 & 6,44 & 6,70 & 4,42 & 8,36 & 8,99 & 8,65 & 10,8 & 9,60 & 8,94 \\
\hline & 7 & 2,79 & 2,80 & 3,54 & 6,63 & 6,86 & 5,84 & 7,00 & 8,02 & 7,60 \\
\hline & 8 & 3,95 & 2,93 & 4,04 & 7,80 & 8,22 & 7,53 & 8,49 & 9,08 & 9,04 \\
\hline & 9 & 5,34 & 6,16 & 6,10 & 8,75 & 8,81 & 9,58 & 8,74 & 9,07 & 10,40 \\
\hline & 10 & 6,90 & 5,29 & 4,65 & 7,32 & 7,55 & 6,92 & 8,75 & 9,65 & 9,02 \\
\hline & 11 & 3,31 & 3,90 & 4,22 & 7,86 & 7,04 & 8,28 & 8,80 & 8,06 & 9,60 \\
\hline & 12 & 4,25 & 5,44 & 3,97 & 8,47 & 6,85 & 7,68 & 9,78 & 10,90 & 8,63 \\
\hline & 13 & 2,99 & 4,69 & 2,66 & 5,79 & 7,44 & 6,03 & 8,26 & 8,63 & 8,33 \\
\hline & 14 & 6,71 & 5,13 & 4,36 & 8,59 & 11,1 & 7,39 & 8,65 & 9,26 & 8,29 \\
\hline & 15 & 6,35 & 7,17 & 5,76 & 7,36 & 7,14 & 9,04 & 8,16 & 7,69 & 8,44 \\
\hline
\end{tabular}


Tabela 17 - Médias das três mensurações de dureza realizadas em cada corpo-de-prova de Kooliner em T0, T30 e T60, para grupos controle e experimental.

\begin{tabular}{|c|c|c|c|c|c|c|}
\hline \multirow[t]{2}{*}{$\mathbf{N}$} & \multicolumn{3}{|c|}{ Controle } & \multicolumn{3}{|c|}{ Experimental } \\
\hline & T0 & T30 & T60 & T0 & T30 & T60 \\
\hline 1 & 2,64 & 5,69 & 6,55 & 6,92 & 8,66 & 9,71 \\
\hline 2 & 6,82 & 8,66 & 9,56 & 1,72 & 5,61 & 6,42 \\
\hline 3 & 3,34 & 5,50 & 7,83 & 9,03 & 6,93 & 10,40 \\
\hline 4 & 3,20 & 4,48 & 5,12 & 1,90 & 4,90 & 5,95 \\
\hline 5 & 6,80 & 6,74 & 9,06 & 6,08 & 8,16 & 9,59 \\
\hline 6 & 3,03 & 5,83 & 6,51 & 5,85 & 8,67 & 9,78 \\
\hline 7 & 5,84 & 8,46 & 9,36 & 3,04 & 6,44 & 7,54 \\
\hline 8 & 7,35 & 8,09 & 8,91 & 3,64 & 7,85 & 8,99 \\
\hline 9 & 5,01 & 6,35 & 9,03 & 5,87 & 9,05 & 9,40 \\
\hline 10 & 7,31 & 8,14 & 8,63 & 5,61 & 7,26 & 9,14 \\
\hline 11 & 8,57 & 8,23 & 9,19 & 3,81 & 7,72 & 8,82 \\
\hline 12 & 3,55 & 7,01 & 6,11 & 4,55 & 7,67 & 9,77 \\
\hline 13 & 6,13 & 7,17 & 7,41 & 3,45 & 6,42 & 8,41 \\
\hline 14 & 5,08 & 6,55 & 6,77 & 5,40 & 9,03 & 8,73 \\
\hline 15 & 9,52 & 9,32 & 9,41 & 6,43 & 7,85 & 8,10 \\
\hline Médias & 5,61 & 7,08 & 7,96 & 4,88 & 7,48 & 8,71 \\
\hline DP & 2,14 & 1,37 & 1,49 & 1,98 & 1,23 & 1,26 \\
\hline
\end{tabular}

Após verificação da distribuição normal e homogenicidade dos dados da tabela 17, foi aplicada a análise de variância $(\mathrm{P}<0,05)$ a dois fatores de variação (grupo e tempo, sendo este vinculado), que indicou diferença para o fator tempo (Tabela 18). Após a comparação das médias (Teste de Tukey: valor $=0,87$ ), pôde-se verificar que houve aumento significante da dureza entre todos os tempos avaliados (Gráfico 3).

Tabela 18 - Análise de variância dos dados de dureza obtidos após ensaio dos corpos-deprova de Kooliner.

\begin{tabular}{llllll}
\hline Fonte de variação & Soma de Quad. & G.L. & Quad. Médios & F & Prob. Ho \\
\hline Grupo & 9,2095 & 1 & 9,2095 & 1,52 & $22,5194 \%$ \\
Resíduo I & 169,0958 & 28 & 6,0391 & & \\
Tempo & 147,9866 & 2 & 73,9933 & 84,50 & $0,0000 \%$ \\
Interação & 0,8889 & 2 & 0,4445 & 0,51 & $38,9727 \%$ \\
Resíduo II & 49,0389 & 56 & 0,8757 & & \\
Variação Total & 376,2197 & 89 & & & \\
\hline
\end{tabular}




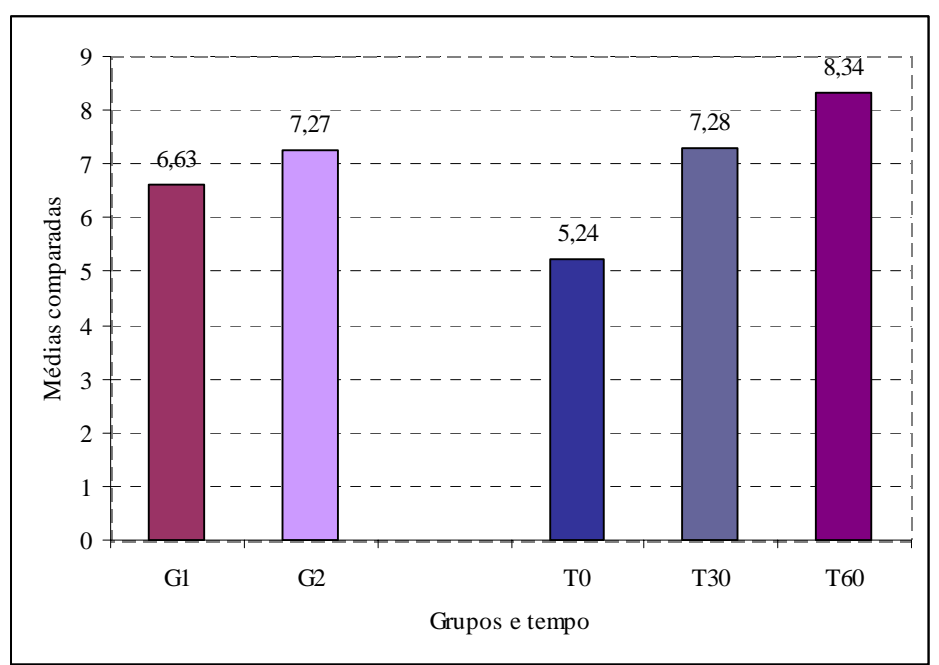

Gráfico 3 - Comparação entre as médias dos tratamentos e dos tempos.

Na tabela 19 estão apresentados os valores referentes ao teste de dureza realizado com os corpos-de-prova de Elite Soft em T0 e após 30 (T30) e 60 (T60) dias de imersão nos grupos controle e experimental, e na tabela 20, as médias das três mensurações obtidas em cada um dos tempos. 
Tabela 19 - Resultados do teste de dureza realizado com os corpos-de-prova de Elite Soft em T0, T30 e T60 após imersão nos grupos controle e experimental.

\begin{tabular}{|c|c|c|c|c|c|c|c|c|c|c|}
\hline \multirow{2}{*}{ Grupo } & \multirow[t]{2}{*}{$\mathbf{N}$} & \multicolumn{9}{|c|}{ Tempos } \\
\hline & & \multicolumn{3}{|c|}{ T0 } & \multicolumn{3}{|c|}{ T30 } & \multicolumn{3}{|c|}{ T60 } \\
\hline \multirow{15}{*}{ Controle } & 1 & 45 & 45 & 46 & 50 & 47,5 & 49 & 49,5 & 50 & 48 \\
\hline & 2 & 46 & 46,5 & 46 & 47,5 & 47,5 & 48 & 49,5 & 51 & 51 \\
\hline & 3 & 46 & 46 & 46 & 49 & 48,5 & 49 & 49 & 51 & 51 \\
\hline & 4 & 45 & 46 & 45,5 & 49 & 48 & 49 & 51 & 52 & 52 \\
\hline & 5 & 45 & 46 & 45 & 51 & 47,5 & 51 & 50 & 51 & 51 \\
\hline & 6 & 44 & 45,5 & 45 & 49 & 49 & 50 & 49,5 & 50,5 & 50,5 \\
\hline & 7 & 47 & 45 & 46 & 50 & 50 & 50 & 51 & 50,5 & 49,5 \\
\hline & 8 & 45 & 47,5 & 46 & 50 & 49 & 50 & 51 & 52 & 50 \\
\hline & 9 & 47 & 46,5 & 47 & 49 & 50 & 50 & 50,5 & 50 & 50 \\
\hline & 10 & 47 & 47,5 & 48 & 50 & 48 & 50 & 50 & 49,5 & 50 \\
\hline & 11 & 48 & 47 & 49 & 49 & 49,5 & 50 & 50 & 50 & 51 \\
\hline & 12 & 47,5 & 48 & 47 & 50 & 51,5 & 49,5 & 51 & 52 & 51,5 \\
\hline & 13 & 46 & 46 & 47 & 48 & 50 & 48,5 & 51,5 & 50 & 51 \\
\hline & 14 & 48 & 48 & 47,5 & 50 & 49 & 50 & 51,5 & 51 & 51,5 \\
\hline & 15 & 48 & 47 & 47,5 & 49 & 49 & 48 & 51 & 51 & 50 \\
\hline \multirow{15}{*}{ Experimental } & 1 & 46 & 44,5 & 49,5 & 50 & 50 & 51,5 & 51 & 52 & 52 \\
\hline & 2 & 45,5 & 47,5 & 47 & 50 & 51,5 & 51 & 52 & 51,5 & 53 \\
\hline & 3 & 44,5 & 45 & 47,5 & 48 & 51 & 49 & 52 & 51,5 & 50,5 \\
\hline & 4 & 45 & 46 & 45 & 48 & 51 & 50 & 51 & 52 & 50,5 \\
\hline & 5 & 43,5 & 45,5 & 47 & 50 & 51 & 50 & 51 & 52 & 51 \\
\hline & 6 & 45 & 47,5 & 46 & 50 & 49,5 & 50 & 50,5 & 52 & 50,5 \\
\hline & 7 & 46 & 45 & 46 & 50 & 50,5 & 51 & 50,5 & 51 & 51 \\
\hline & 8 & 45 & 47 & 45 & 49 & 50 & 49,5 & 49,5 & 50,5 & 50 \\
\hline & 9 & 46 & 45 & 44,5 & 51 & 50 & 49,5 & 50,5 & 51 & 51 \\
\hline & 10 & 46,5 & 47,5 & 47,5 & 50 & 51 & 49 & 50 & 52 & 51 \\
\hline & 11 & 44,5 & 48 & 48,5 & 49,5 & 50,5 & 49 & 49 & 50,5 & 50 \\
\hline & 12 & 47 & 47 & 47 & 50 & 50,5 & 50 & 50 & 50,5 & 51 \\
\hline & 13 & 48 & 49 & 48,5 & 48 & 51,5 & 52 & 52 & 51,5 & 51,5 \\
\hline & 14 & 46 & 48,5 & 48 & 50,5 & 52 & 52,5 & 50,5 & 51 & 50,5 \\
\hline & 15 & 48 & 49 & 48 & 49 & 50 & 49 & 52 & 50 & 50,5 \\
\hline
\end{tabular}


Tabela 20 - Médias das três medidas de dureza realizadas em cada corpo-de-prova de Elite soft, para T0, T30 e T60 após imersão nos grupos controle e experimental.

\begin{tabular}{cccccccc}
\hline $\mathbf{N}$ & \multicolumn{3}{c}{ Grupo Controle } & & \multicolumn{3}{c}{ Grupo experimental } \\
\cline { 2 - 3 } \cline { 6 - 7 } & T0 & T30 & T60 & & T0 & T30 & T60 \\
\hline $\mathbf{1}$ & 45,3 & 48,8 & 49,1 & & 46,6 & 50,5 & 51,6 \\
$\mathbf{2}$ & 46,1 & 47,6 & 50,5 & & 46,6 & 50,8 & 52,1 \\
$\mathbf{3}$ & 46 & 48,8 & 50,3 & & 45,6 & 49,3 & 51,3 \\
$\mathbf{4}$ & 45,5 & 48,6 & 51,6 & & 45,3 & 49,6 & 51,1 \\
$\mathbf{5}$ & 45,3 & 49,8 & 50,6 & & 45,3 & 50,3 & 51,3 \\
$\mathbf{6}$ & 44,8 & 49,3 & 50,1 & & 46,1 & 49,8 & 51 \\
$\mathbf{7}$ & 46 & 50 & 50,3 & & 45,6 & 50,5 & 50,8 \\
$\mathbf{8}$ & 46,1 & 49,6 & 51 & & 45,6 & 49,5 & 50 \\
$\mathbf{9}$ & 46,8 & 49,6 & 50,1 & & 45,1 & 50,5 & 50,8 \\
$\mathbf{1 0}$ & 47,5 & 49,3 & 49,8 & & 47,1 & 50 & 51 \\
$\mathbf{1 1}$ & 48 & 49,5 & 50,3 & & 47 & 49,6 & 49,8 \\
$\mathbf{1 2}$ & 47,5 & 50,3 & 51,5 & & 47 & 50,1 & 50,5 \\
$\mathbf{1 3}$ & 46,3 & 48,8 & 50,8 & & 48,5 & 50,5 & 51,6 \\
$\mathbf{1 4}$ & 47,8 & 49,6 & 51,3 & & 47,5 & 51,6 & 50,6 \\
$\mathbf{1 5}$ & 47,5 & 48,6 & 50,6 & & 48,3 & 49,3 & 50,8 \\
\hline Médias & $\mathbf{4 6 , 4 3}$ & $\mathbf{4 9 , 2 1}$ & $\mathbf{5 0 , 5 2}$ & & $\mathbf{4 6 , 4 8}$ & $\mathbf{5 0 , 1 2}$ & $\mathbf{5 0 , 9 5}$ \\
$\mathbf{D P}$ & $\mathbf{1 , 0 2}$ & $\mathbf{0 , 6 8}$ & $\mathbf{0 , 6 5}$ & & $\mathbf{1 , 0 8}$ & $\mathbf{0 , 6 3}$ & $\mathbf{0 , 6 0}$ \\
\hline
\end{tabular}

Após verificação da distribuição normal e homogenicidade dos dados da tabela 19, eles foram submetidos à análise de variância $(\mathrm{P}<0,05)$, a dois fatores de variação (grupo e tempo, sendo este vinculado), que indicou diferença significante entre os dois fatores (Tabela 21). No gráfico 4, pode -se verificar as médias comparadas.

Tabela 21 - Análise de variância dos dados de dureza obtidos após ensaio dos corpos-deprova de Elite soft.

\begin{tabular}{llllll}
\hline Fonte de variação & Soma de Quad. & G.L. & Quad. Médios & F & Prob. H0 \\
\hline Grupo & 4,64 & 1 & 4,64 & 5,43 & $2,57 \%$ \\
Resíduo I & 23,97 & 28 & 0,85 & & \\
Tempo & 297,94 & 2 & 148,97 & 273,02 & $0,00 \%$ \\
Interação & 3,00 & 2 & 1,50 & 2,75 & $7,07 \%$ \\
Resíduo II & 30,55 & 56 & 0,54 & & \\
Variação Total & 360,12 & 89 & & & \\
\hline
\end{tabular}




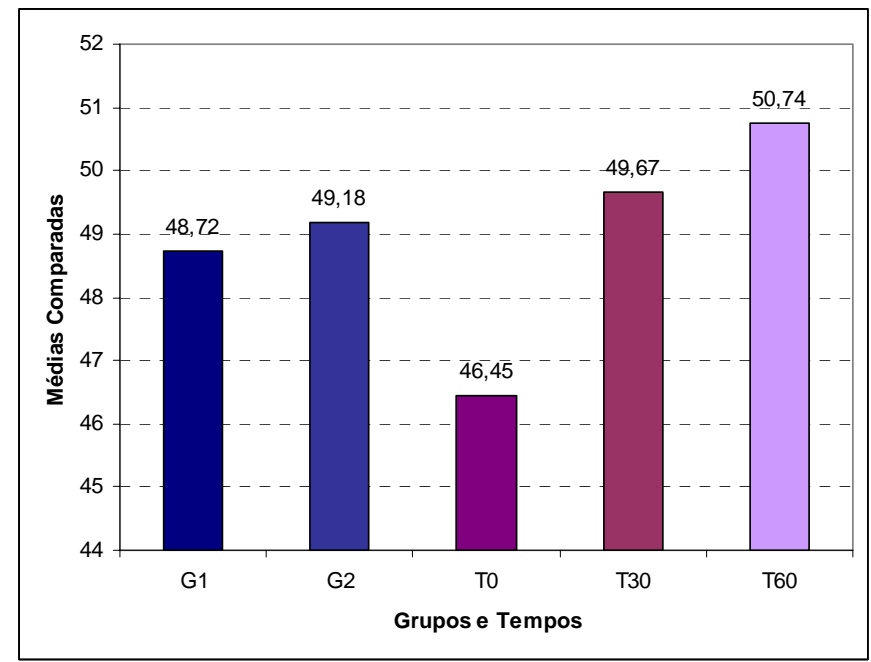

Gráfico 4 - Comparação entre as médias dos grupos e dos tempos.

Os corpos-de-prova de Elite soft do grupo experimental apresentaram um aumento na dureza quando comparado ao grupo controle $(\mathrm{P}<0,05)$. Para o fator tempo, o teste complementar de Tukey (valor $=0,76$ ), indicou diferença significante entre as três médias $(\mathrm{P}<0,05)$, sendo que houve um aumento na dureza de T0 para T60 . 


\section{DISCUSSÃO}

\section{Considerações iniciais}

Os reembasadores de próteses totais foram introduzidos na Odontologia a mais de um século (MACK, 1989). Uma das primeiras resinas sintetizadas como um reembasador macio foi a resina de polivinil plastificada (MATHEUS, 1945), seguida pela introdução de silicones (LAMMIER; STORER, 1958).

Os reembasadores macios têm como principal função, atuar na sorção e distribuição da força mastigatória às áreas de suporte primário do rebordo alveolar do edentado. Os reembasadores macios promovem conforto aos pacientes que não podem suportar pressão oclusal, como nos casos de rebordo alveolar muito reabsorvido e/ou flácido (WRIGHT, 1976). Em adição, o uso de reembasadores macios tem crescido nos casos de pacientes com câncer que apresentam defeitos pós-operatórios que requerem obturação e nos casos de próteses transicionais após o estágio I e II da cirurgia para colocação de implantes (RUSSELL, 1976).

Atualmente, os materiais reembasadores disponíveis no mercado dividem-se em dois tipos principais: materiais à base de resina, e à base de silicone (EL-HADARY; DRUMMOND, 2000; SINOBAD et al., 1992, QUDAH; HUGGETT; HARRISON, 1991). Os materiais à base de silicone são compostos basicamente de polímeros de dimetilsiloxano que possuem ligações cruzadas que controlam sua maciez. Geralmente, apresentam boas propriedades elásticas (AMIN; FLETCHER; RITCHIE, 1981; McCABE, 1976) e não é necessária a adição de plastificantes para obter resiliência. Os materiais à base de silicone retornam as suas formas originais quase imediatamente após a remoção da carga devido ao seu grande número de ligações cruzadas (McCABE, 1976). Os materiais à base de resina 
acrílica são geralmente compostos de polímeros e co-polímeros acrílicos e contém plastificantes. Estes plastificantes abaixam a temperatura de transição vítrea do polímero próximo à temperatura bucal, diminuindo o módulo de elasticidade a um nível aceitável. O que varia nestes materiais é a quantidade de plastificante e o tipo de monômero acrílico, dependendo das diferentes marcas comerciais. Além disso, quando o solvente é o etilálcool ou etilacetato, pode-se esperar que estes materiais apresentem rápido endurecimento, pelo fato de serem eliminados nos fluídos bucais (McCABE, 1976).

Os materiais reembasadores à base de resina acrílica apresentam componentes similares à resina acrílica e acabam formando uma rede de moléculas entre as duas superfícies de união de composições similares (AMIN; FLETCHER; RITCHIE, 1981). Dessa forma, os materiais à base de resina acrílica apresentam melhor união com a base de prótese quando comparados aos materiais à base de silicone sem adesivo.

Segundo Qudah, Harrison e Huggett (1990), para que os materiais resilientes desempenhem sua função com a máxima eficácia, é necessário que apresentem fácil técnica de processamento, mínima sorção de água e solubilidade, manutenção da resiliência, boa adesão à base da prótese, boa resistência à ruptura, estabilidade dimensional, fácil higienização, atoxicidade e ausência de odores.

A escolha dos materiais avaliados nesta pesquisa fundamenta-se no fato de que, os materiais à base de resina acrílica apresentam componentes similares à resina acrílica termopolimerizável utilizada para base de próteses totais. Já os materiais à base de silicone são citados como materiais resilientes com maior estabilidade dimensional e durabilidade no meio bucal (HEKIMOGLU; ANIL, 1999; WILSON, 1989).

Existem na literatura, vários autores que avaliam os materiais reembasadores para base de próteses totais. Portanto, o intuito maior no presente trabalho foi avaliar esses materiais 
quando uma solução de higiene para dentaduras foi empregada. Sabe-se que o método mais comumente utilizado na higiene de próteses totais convencionais, ou seja, de resina acrílica termopolimerizável, é a escovação (ABELSON, 1985, TARBET et al., 1984). Porém, a literatura informa que esta técnica não é viável quando um material reembasador está associado à base protética por causar danos à superfície e diminuir sua longevidade (BOTEGA et al., 2004; MAKILA; HONKA, 1979; OLIVEIRA et al, 2007).

Talvez a maior desvantagem ou causa de falhas dos materiais resilientes é a dificuldade em mantê-los limpos (MAKILA; HONKA, 1979). A rotina de limpeza destes materiais é recomendada para remover e prevenir o acúmulo de biofilme (BUTZJORGENSEN, 1979), o que pode resultar em degradação do material ou instalação de processos patológicos, como a estomatite protética (GRAHAM et al., 1991; NIKAWA et al., 2000).

Os agentes químicos de limpeza podem apresentar-se como peróxidos ou hipocloritos alcalinos, desinfetantes, ácidos e enzimas. O agente químico considerado ideal deve ser efetivo na remoção de depósitos orgânicos e inorgânicos, possuir propriedades bactericidas e fungicidas. Além disso, ser compatível com todos os materiais da prótese e de baixo custo (ABELSON, 1985; JAGGER; HARRISON, 1995). Os peróxidos e hipocloritos são os agentes químicos de limpeza mais comuns. Os agentes à base de peróxido possuem ação bactericida, além de auxiliar na remoção de manchas (ABELSON, 1985; JAGGER; HARRISON, 1995). Os hipocloritos são altamente eficazes na remoção de manchas leves, além de possuírem ação bactericida e fungicida (ABELSON, 1985). Apesar de não dissolverem o cálculo, inibem sua formação, pois atuam sobre a matriz do biofilme (BUDTZ-JORGENSEN, 1979; JAGGER; HARRISON, 1995). 
Em estudo in vitro, foi observado que peróxidos alcalinos e ácidos, em geral, aumentam a dureza dos materiais do tipo acrílico, sugerindo que estes tipos de agentes químicos de limpeza não devem ser utilizados para estes materiais (BATES; SMITH, 1965). Outros fatores também podem alterar a dureza, como a termociclagem (HEKIMOGLU; ANIL; HEKIMOGLU; SAHIN, 1999; QUDAH; HUGGETT; HARRISON, 1991) ou o armazenamento em água (BATES; SMITH, 1965). Nos materiais à base de resina acrílica, esse endurecimento ocorre devido à lixiviação de plastificantes (DAVENPORT; WILSON; SPENCE, 1986). Porém, materiais à base de silicone mostram diminuição dos valores de dureza, devido à sorção de líquidos pela presença de carga nesse tipo de material (QUDAH; HUGGETT; HARRISON, 1991).

Estudos in vitro (DAVENPORT; WILSON; SPENCE, 1986; JIN et al., 2003; MINAGI et al., 1987; MOORE; SMITH; KENNY, 1984; NIKAWA et al., 2003) e in vivo (DILLS et al., 1988; GORNITSKY et al., 2002, KULAK et al., 1997; MOORE; SMITH; KENNY, 1984; RAHAL; MESQUITA, 2003) já foram realizados comprovando a eficácia de agentes químicos na limpeza de próteses. Outros estudos mostraram que essas substâncias, quando utilizadas isoladamente, não são efetivas na remoção do biofilme sobre as próteses (ABELSON, 1981; ODMAN, 1992; SESMA et al., 1999, TARBET et al., 1984). Porém, como estas soluções químicas podem causar deterioração da superfície e alteração dos valores de dureza dos reembasadores resilientes, deve-se escolher um agente químico de limpeza compatível com estes materiais (NIKAWA et al., 2003). 


\section{Sorção e solubilidade}

Dentre as propriedades dos materiais reembasadores avaliados após a imersão em perborato de sódio foram incluídas a sorção e solubilidade, das quais depende a estabilidade em longo prazo dos materiais reembasadores. Idealmente, um reembasador deveria apresentar baixos valores de sorção e solubilidade, uma vez que estas propriedades estão diretamente relacionadas à perda de adesão à base da dentadura, alteração de cor, deterioração da superfície, acúmulo de biofilme e desenvolvimento de microrganismos e perda de resiliência.

Atualmente, não há uma especificação da ADA para os materiais reembasadores macios. De acordo com a especificação $\mathrm{n}^{0} 12$ da ADA (1975), a qual diz respeito a polímeros para bases de prótese totais, os valores de sorção após uma semana, não deveriam ser maiores que $0,8 \mathrm{mg} / \mathrm{cm}^{2}$ e os valores de solubilidade não deveriam ser maiores que $0,04 \mathrm{mg} / \mathrm{cm}^{2}$.

Estudos prévios têm avaliado a sorção e solubilidade dos reembasadores após imersão em água destilada. No entanto, com o uso diário, as próteses ficam imersas em saliva e podem ser mantidas em solução higienizadora ou em água, nos períodos de descanso, o que causa a solubilização de seus componentes, como os agentes plastificantes, e conseqüente sorção de água (HEKIMOGLU; ANIL, 1999). Neste estudo, a sorção e solubilidade dos materiais foram avaliadas após imersão em saliva artificial, uma vez que foi comprovado por Kazanji e Watkinson (1988), que a solubilidade de alguns materiais reembasadores resilientes imersos em saliva artificial foi significativamente maior quando comparada à imersão em água. Segundo os autores, a perda de peso provavelmente ocorreu porque os plastificadores são mais solúveis em solução iônica do que em água. Inversamente, os autores encontraram que a porcentagem de sorção foi significativamente menor na saliva em comparação à imersão em água destilada. 
Quando considerado o controle clínico do biofilme dos materiais resilientes, o efeito do higienizador depende de muitos fatores incluindo composição e tempo de ação. Devido ao fato dessas soluções químicas poderem provocar deterioração significante dos materiais reembasadores, a compatibilidade entre os materiais deve ser considerada para eliminar ou minimizar as alterações de propriedades.

Várias pesquisas já demonstraram que os métodos de desinfecção propostos como a utilização de soluções químicas bem como a energia de microondas, são aplicados sobre a resina acrílica convencional para próteses totais, mantendo suas propriedades físicas e mecânicas satisfatórias. Para os materiais reembasadores macios, a eficiência dos métodos e as possíveis alterações em suas propriedades físicas ainda não estão bem estabelecidas.

Neste estudo foram avaliadas a sorção e a solubilidade de dois materiais reembasadores com características diferentes, ou seja, o Kooliner ä base de resina acrílica e o Elite soft, ä base de silicone, quando imersos em saliva artificial (Grupo 1) e com imersões diárias em perborato de sódio (Corega Tabs, Grupo 2), após um período de 120 dias. Após análise dos resultados, pôde-se verificar que os valores obtidos para sorção do Kooliner foram significativamente maiores ( $\left.\mathrm{G} 1=1,43 \mathrm{mg} / \mathrm{cm}^{2} \pm 0,13 ; \mathrm{G} 2=1,63 \mathrm{mg} / \mathrm{cm}^{2} \pm 0,50\right)$ do que os do Elite soft $\left(\mathrm{G} 1=0,29 \mathrm{mg} / \mathrm{cm}^{2} \pm 0,10 ; \mathrm{G} 2=0,51 \mathrm{mg} / \mathrm{cm}^{2} \pm 0,18\right)$. Estes resultados estão de acordo com ElHadary e Drummond (2000) que avaliaram a sorção e solubilidade de dois reembasadores macios e observaram que o material a base de resina acrílica apresentou maior solubilidade do que o material a base de silicone.

Os trabalhos que avaliam as propriedades dos materiais resilientes são vários e dessa forma, muitas são as marcas dos materiais testados, dificultando comparações objetivas. No entanto, pelo agrupamento quanto à composição, ou seja, à base de polímero e de silicone, 
pode-se dizer que os resultados deste estudo também estão de acordo com o trabalho realizado por Braden e Wright (1983) onde estudaram a sorção e solubilidade de 11 reembasadores resilientes: cinco à base de silicone e seis à base de resina acrílica. Nos materiais à base de silicone, os autores verificaram menor sorção de água por apresentarem aglutinante em sua composição química.

De acordo com Kazanji e Watkinson (1988), os materiais reembasadores podem absorver ou perder componentes solúveis, dependendo se sua composição e da solução na qual eles foram imersos. É sabido que a alta concentração iônica (potássio e sódio) dos higienizadores de dentaduras comparada com a água causa maior dissolução dos componentes solúveis. Hekimoglu e Anil (1999), encontraram valores de sorção maiores que 0,80mg/cm² após 15 dias de imersão em água e observaram uma diminuição desses valores com 30 dias de imersão, o que pode ser explicado pela saturação de água sofrida pelos materiais testados ao longo dos 30 dias de imersão. No presente estudo, o uso do perborato de sódio não interferiu na sorção do Kooliner, mas promoveu um aumento significante na sorção do Elite soft (Tabela 4, gráfico 1).

A sorção de água depende do grau de hidrofobicidade e porosidade do material. A presença de agentes cross-linking tem sido citada como um fator que favorece a menor sorção de água. Uma tendência similar foi encontrada no presente estudo. O reembasador com agentes cross linking (Elite soft) absorveu menos água do que aquele sem esses agentes (Kooliner). Arima, Murata e Hamada (1996) encontraram comportamento semelhante do Kooliner. A baixa sorção de água do reembasador com cross-linking pode ser atribuída ao efeito da adição do fluoreto, o qual desenvolve alta hidrofobicidade.

De acordo com os resultados, verificou-se que, em comparação com as resinas acrílicas (especificação no. 12 da $\mathrm{ADA}$ ), a sorção do material a base de resina acrílica foi 
elevada. Isto pode ser explicado pela presença de impurezas solúveis que, em contato com a água diluem-se, criando espaços vazios. Esses espaços são preenchidos por água formando gotículas. As gotículas crescem até que as forças elásticas e osmóticas se equilibrem (PARKER; BRADEN, 1989). O material à base de silicone, porém, apresentou valores adequados se comparados à especificação da ADA citada acima. Kawano, Dootz e Koran, (1994), concluíram que, após uma semana, os reembasadores do tipo polímero ou copolímero (Flexor e Durosoft), e os reembasadores do tipo silicone (Molloplast-B e Prolastic) apresentaram valores de sorção concordes com a Especificação $N^{\circ} 12$ da ADA. Entretanto, após um ano, somente os materiais à base de silicone apresentaram valores adequados.

Com relação à solubilidade, o Elite soft apresentou os menores valores, sendo que a diferença com o Kooliner foi estatisticamente significante. O meio de imersão utilizado também promoveu alteração significante na solubilidade do Kooliner (Tabela 8 e Gráfico 2). Estes resultados estão de acordo com Garcia et al. (2003) e Goll, Smith e Plein (1983), que encontraram uma diminuição no peso dos materiais resilientes após 30 dias de imersão em água e higienizador.

Os resultados obtidos em relação à solubilidade dos materiais resilientes são importantes porque permitem a determinação de qual foi o sistema resiliente que apresentou maior liberação de componentes solúveis para o meio oral, originando uma diminuição da sua resiliência, e conseqüentemente deterioração de suas propriedades elásticas (AMIN; FLETCHER; RITCHIE, 1981). 


\section{Alteração de cor}

O processo de envelhecimento acelerado tem sido utilizado na verificação das mudanças de cor e nas propriedades físicas de vários materiais resilientes (ANIL; HEKIMOGLU; SAHIN, 1999; DOOTZ; KORAN; CRAIG, 1993; WAGNER et al., 1995). Neste estudo, um higienizador de dentaduras à base de perborato de sódio foi utilizado como um agente simulador de envelhecimento dos reembasadores testados. Segundo Jin et al. (2003), os fatores que podem contribuir para a alteração de cor dos materiais são vários. Dentre eles incluem-se acúmulo de manchas, desidratação e oxidação das ligações duplas de carbono que ao reagiram com peróxido (presente em algumas soluções de higiene) produzem compostos coloridos e degradação contínua de produtos coloridos. Embora o processo de alteração de cor dos materiais reembasadores não seja conhecido exatamente, a alteração de cor dos materiais deveria ser atribuída aos diferentes corantes que entram em contato com meio bucal, às alterações inerentes do próprio material, ou ambas.

Para mensuração da variação de cor, os corpos-de-prova foram avaliados imediatamente após sua confecção e após 30 e 120 dias de imersão por meio do sistema CIE LAB, frequentemente empregado na literatura (CANAY et al., 1999; JIN et al., 2003; MA; JOHNSON; GORDON, 1997; TAN et al., 2000). Villar et al (2003) utilizou metodologia computadoriza (Photoshop software, Adobe Systems, San Jose, CA) para análise da cor, porém seu estudo foi realizado in vivo sem a destruição das amostras. Segundo os autores, o sistema tem a capacidade de capturar valores de cor vermelho, verde e azul bem como o CIE LAB

Por meio da análise dos resultados estatísticos do presente estudo, pôde-se verificar diferença estatística entre os fatores material (Kooliner: $\mu=4,0$, $\mathrm{DP}=0,63$; Elite soft: $\mu=8,17$, 
$\mathrm{DP}=1,75)$ e tempo $(\Delta \mathrm{t} 0-\mathrm{t} 30: \mu=5,12, \mathrm{DP}=1,84 ; \Delta \mathrm{t} 0-\mathrm{t} 120: \mu=7,04, \mathrm{DP}=3,05)$. A diferença encontrada entre os materiais não pode ser indicativa de problemas com ou outro, uma vez que cada um deles apresenta cores características diferentes. Quanto ao período, pôde-se verificar que, de modo geral, houve alteração de cor ao longo do tempo. Da diferença estatística encontrada entre as interações Grupo/Material, Tempo/Grupo e Tempo/Material é importante salientar que o uso do perborato de sódio não promoveu alteração de cor dos materiais (Tabela 12) e ainda que, não houve diferença entre os grupos no intervalo de 30 dias ou de 120 dias, porém nota-se diferença entre os intervalos de tempo. Tanto para o grupo controle como para o grupo experimental, houve aumento da alteração de cor nos intervalos de zero a 30 dias e de zero a 120 dias (Tabelas 13 e 14).

Por meio da análise crítica da alteração de cor com base na classificação NBS pôde-se verificar que os corpos-de-prova de Kooliner imersos no grupo 1, no intervalo de 30 dias, sofreram alteração apreciável e os do grupo 2, alteração notável. No intervalo de 120 dias, o Kooliner sofreu alteração de cor apreciável em ambos os grupos. O material Elite soft sofreu alta alteração de cor nos grupos e intervalos de tempos avaliados. A estabilidade de cor pode depender da composição química do material (PURNAVEJA et al, 1982). Superfícies hidrofóbicas podem absorver pigmentos por meio de uma interação hidrofóbica.

Jin et al. (2003) verificaram, em estudo clínico, alteração de cor severa após imersão de reembasadores à base de resina acrílica em higienizadores químicos. Em contraste, um material à base de silicone mostrou os melhores resultados com relação a esta variável, resultados estes, contrários aos deste estudo. Segundo os autores, algumas das alterações de cor verificadas foram em tom de azul claro, embora as soluções testadas se apresentassem quase incolor. No entanto, considera-se que os corantes dos higienizadores não afetam seriamente a estabilidade de cor dos materiais reembasadores quando comparados aos 
corantes alimentares como chá e café e outros como o cigarro. Sendo assim, especula-se que as mudanças de cores observadas podem ser atribuídas à mudança na matriz dos materiais, tais como inibição, hidrólise e decomposição de cadeias de reação. No entanto, mais estudos são necessários para esclarecer o mecanismo de alteração de cor.

Resultados semelhantes foram encontrados por Canay et al. (1999) ao imergir reembasadores ä base de polimetilmetacrilato e de silicone em corantes alimentares. O material resinoso apresentou maior alteração de cor quando comparado aos materiais ä base de silicone avaliados. A alteração de cor é uma propriedade dos materiais reembasadores intimamente ligada à sorção de líquidos pelo material (NIMEROFF, 1968, POWERS; DENNISON; KORAN, 1978;). No presente estudo, os maiores valores de sorção foram apresentados pelo Kooliner, porém de forma geral, sem considerar período ou grupo de imersão, o Elite soft foi o material que apresentou a maior alteração de cor. De forma geral, a alteração nos pesos dos materiais ocorreu nos 7 primeiros dias, momento em que provavelmente ocorreu grande sorção de fluidos e solubilidade de componentes do material. No intervalo de 30 dias, a alteração de cor do Kooliner foi de 67,14\% e a do Elite soft foi de 77,78\% da alteração que ocorreu em 120 dias. Isto é, grande parte da alteração de cor aconteceu nos primeiros dias, acompanhando o período de alteração de peso do material.

Tan et al. (2000), ao avaliar um material á base de silicone (Molloplast B) verificaram que a alteração de cor do material depende do tipo de higienizador e do acabamento da superfície. Quanto maior a rugosidade superficial do material, maior sua suscetibilidade ä alteração de cor. Ma, Johnson e Gordon (1997) verificaram alteração de cor de quatro materiais para reembasamento de próteses totais após imersão em soluções higienizadoras.

De acordo com Johnson e Kao (1989) se a variação de cor $(\Delta \mathrm{E})$ for menor que 1 , segundo NBS, esta variação é considerada muito pequena e entre 1 e 2 , a situação é 
clinicamente aceitável. Goldstein e Schmitt (1993), em suas observações concluíram que quando o $\Delta \mathrm{E}$ exceder 3,7 o material assumirá uma qualidade visual clinicamente detectável. No presente estudo, os materiais avaliados apresentaram valores maiores que 2 (tabela 15), indicando uma alteração de cor, clinicamente perceptível. A manutenção da cor do material é importante para os pacientes, uma vez que os pacientes apresentam-se mais satisfeitos quando o material reembasador se mantém estável e com a cor indistinguível do material de base da prótese, e a motivação para manter a higiene da dentadura depende da facilidade da limpeza e da ausência de manchas (VILLAR et al., 2003).

Neste estudo os materiais avaliados foram obtidos pela técnica direta, ou seja, com polimerização em temperatura ambiente. Segundo Matsumura et al. (2001) um dos problemas relacionados com a polimerização do material no interior da cavidade bucal é justamente a estabilidade de cor. Entre os demais fatores ligados a esta ocorrência, citados anteriormente, podese relacionar também uma camada superficial do material com baixa polimerização. Yatabe et al. (1999) relataram que a superfície do material reembasador, incluindo Tokuso Rebase é facilmente manchada na presença de uma camada onde a polimerização não ocorre perfeitamente e que a espessura desta camada é dependente da temperatura de polimerização, da presença do oxigênio e da proporção pó-líquido. Jin et al. (2003) não detectaram diferenças significantes com os higienizadores de dentadura nos quais materiais reembasadores termopolimerizáveis foram imersos. Segundo os autores, isto pode ser atribuído ao fato de que a termopolimerização proporciona uma maior estabilidade das propriedades físicas dos materiais.

No presente trabalho, os dois materiais apresentaram alteração de cor, porém nota-se que o meio de imersão não foi o fator que mais colaborou com esta alteração, mas que tempo foi o fator que mais proporcionou mudanças de cor. Resultados semelhantes foram encontrados por Feitosa et al. (2003) 


\section{Dureza}

De acordo com muitos autores, a eficácia dos materiais reembasadores macios é atribuída às propriedades viscoelásticas, que depende da quantidade de força aplicada sobre os materiais. Em virtude desta elasticidade, o material poderá se deformar quando submetido a uma força e retornar ao estado original quando a força for removida. Contudo, a sua recuperação não é instantânea devido a viscoelasticidade do material.

Clinicamente, esta característica está relacionada com a função de absorver e redistribuir a energia gerada pelas forças oclusais durante a função da prótese. Kawano, Dootz e Koran (1994) complementaram que além dos materiais reembasadores macios distribuírem uniformemente o impacto das forças funcionais para os tecidos de suporte, também reduzem a energia gerada pelas forças mastigatórias.

Uma forma simples de se obter a medida do módulo de elasticidade ou a maciez de um elastômero é por meio do ensaio de dureza baseado na mensuração da resistência à penetração de um indentador quando uma força é aplicada.

A literatura não estabelece um valor ideal de dureza para os reembasadores macios. Craig e Gibbons (1961) sugeriram que quanto maior a maciez do material, maior a extensão em absorver os efeitos de impactos. Dessa forma, baixa dureza é característica desejável para os reembasadores macios. Entretanto, os materiais à base de resina acrílica endurecem rapidamente, devido a perda de seus agentes plastificantes, enquanto os materiais à base de silicone, sofrem mínimas mudanças coesivas, permanecendo macios indefinidamente. O ideal seria um material com adesão semelhante aos à base de resina, e que permanecessem macios durante tempos prolongados, como os à base de silicone (CANAY et al. 1.999).

A manutenção da dureza constitui um dos fatores mais difíceis na utilização dos reembasadores de próteses totais, já que a maioria deles não é estável em meio aquoso como a 
cavidade oral. Durante sua utilização, são imersos em saliva, água ou soluções de higiene, o que causa solubilização de componentes, como os agentes plastificantes, e conseqüentemente sorção de água. Segundo Hekimoglu e Anil (1999), alta sorção e solubilidade são associadas com inchaço, distorção, endurecimento, sorção de odores, suporte para crescimento de microrganismos, alterações de cor e deslocamento do reembasador da base da dentadura.

Este trabalho teve como objetivo verificar a influência do uso de um agente higienizador à base de perborato de sódio (Corega Tabs) na dureza de dois materiais reembasadores. Para o Kooliner, o teste de dureza foi realizado com “Microhardness Tester Shimadzeu”, com uma carga de 25g por 5 segundos (AZEVEDO et al., 2005) por tratar-se de material reembasador rígido; para o Elite soft, foi utilizado o "Shore A Durometer" (Instrument and Manufacturing Co Inc, Frieport, N.Y.) com força de 1Kg (ASTM 2240-64T), o qual indica a resistência relativa de um material à penetração de uma ponta sob força de ação constante.

Como foram avaliados materiais diferentes, ou seja, reembasador à base de resina acrílica (Kooliner) e outro à base de silicone (Elite soft), não foi realizada comparação entre os materiais, mas sim, o comportamento deles em relação ao produto de imersão (Grupos 1 e 2) perborato de sódio, e o período de imersão (T0, T30 e T60 dias).

Para o Kooliner, foi observado que a imersão em perborato de sódio não influenciou significativamente na propriedade de dureza (Kooliner: G1=6,63 $\pm 1,66$ e G2=7,27 $\pm 1,49$ ). Estes resultados estão de acordo com Haywood et al. (2003) que investigaram os efeitos do uso diário de três higienizadores de próteses totais (Steradent 3 Minutos e Steradent Fresh, a base de peróxido; Dentural, a base de hipoclorito), na dureza de 3 materiais reembasadores resilientes à base de resina acrílica (Tokuso Rebase Fast Set. Coe, Kooliner e Total Hard) por um período de 6 meses, e concluíram que a dureza não sofreu alteração pelo período testado 
no experimento. Para o Elite soft $(G 1=48,72 \pm 1,17 ; G 2=49,18 \pm 0,77)$, pôde-se verificar que houve diferença entre os grupos. Davenport, Wilson e Spence (1986) não observaram diferença nos valores de dureza do material à base de silicone imerso em soluções de peróxido e hipoclorito alcalinos. Materiais que apresentam agentes cross-linking em sua composição demonstram maior estabilidade de dureza quando armazenados em água. O Kooliner não apresenta este tipo de componente, diferentemente do Elite soft, no entanto os dois materiais tiveram diferentes padrões de comportamento frente ao produto de higiene.

Por meio dos achados literários, nota-se que não há um consenso quanto aos resultados obtidos. Pavan et al. (2007), que avaliou a dureza de materiais reembasadores resilientes a base de resina acrílica e silicone após a imersão em glutaraldeído a 2\% e desinfecção em microondas e observaram que o higienizador promoveu os maiores valores de dureza nos materiais testados. Para os materiais a base de resina acrílica, o que pode ter acontecido foi uma maior evaporação dos agentes plastificantes presentes nos materiais. Bates e Smith (1965), observaram aumento dos valores de dureza de materiais à base de silicone termopolimerizáveis imersos em peróxido alcalino. Tan et al. (2000), demonstraram que as médias de dureza do material Molloplast-B (à base de silicone) diminuíram após o tratamento com diferentes soluções de limpeza após quatro meses e meio de imersão. Estes resultados estão de acordo com os encontrados por Oliveira et al. (2007).

Segundo Davenport, Wilson e Spence (1986) e Qudah, Huggett e Harrison (1991), os materiais à base de resina acrílica possuem em sua composição plastificantes, que são responsáveis pela resiliência do material, e a lixiviação desse componente acarreta no seu enrijecimento. Já os materiais à base de silicone não possuem plastificantes, mas contém em sua composição carga, e a sorção de água pela presença desse componente, promove aumento dos valores de dureza dos materiais resilientes (QUDAH; HUGGETT; HARRISON, 1991). 
Quanto ao fator tempo, ao longo dos 60 dias de imersão, pôde-se notar um aumento da dureza, em ambos os grupos, para os dois materiais, sendo este aumento significativo (Gráficos 3 e 4). Craig e Gibbons (1961) encontraram resultados semelhantes ao analisar, entre outras propriedades, a dureza de reembasadores resilientes, 24 horas após o seu processamento e diariamente, durante 20 semanas, em amostras armazenadas em água destilada. Os valores encontrados variaram bastante entre as marcas comerciais testadas após a imersão em água por vinte semanas. Alguns materiais chegaram a ter seu valor próximo ao de uma base rígida de resina acrílica. Polyzois e Frangou (2001) avaliando a dureza de resina acrílica resiliente e de materiais para forramento ao longo do tempo e com variação nos procedimentos de polimerização, encontraram resultados diferentes, uma vez que verificaram um aumento da dureza em todos os materiais durante o primeiro mês de imersão, e após o qual houve uma estabilização dos valores de dureza.

A dureza é uma propriedade de extrema importância que os materiais resilientes, tanto à base de resina quanto à base de silicone, devem apresentar por um longo período para que cumpram eficazmente com sua função. No entanto, nota-se pelos achados da literatura e pelos resultados do presente estudo que o tempo é um fator limitante. Dessa forma, estudos devem ser conduzidos com o intuito de promover a manutenção da manutenção dos materiais resilientes para que sua indicação clínica seja realizada com convicção. 


\section{CONCLUSÕES}

Por meio dos resultados obtidos, pôde-se concluir:

1. O uso diário do perborato de sódio não promoveu alteração nas médias de sorção do material Kooliner, o qual apresentou médias significativamente maiores, tanto para o grupo 1 quanto para o 2, quando comparadas ao Elite soft. No entanto, as imersões diárias do Elite soft em perborato de sódio causaram aumento significante em seus valores de sorção.

2. Quanto à solubilidade, o material Kooliner apresentou os maiores valores em relação ao Elite soft e, em ambos os materiais, as menores médias de solubilidade foram apresentadas quando imersos diariamente em perborato de sódio.

3. A maior alteração de cor foi apresentada pelo Elite soft. Com relação aos fatores grupos de imersão e tempo, este foi o fator que proporcionou alterações significantes na cor de ambos os materiais.

4. A dureza do Kooliner não sofreu alteração por influência das imersões em perborato de sódio, mas sim pelo período de imersão, o qual promoveu aumento significante da dureza ao longo do período avaliado. O material Elite soft teve sua propriedade de dureza aumentada por influência tanto do uso do higienizador quanto pelo período de imersão.

O perborato de sódio não influenciou de forma significante nas propriedades avaliadas neste estudo. Dentre os materiais, o Kooliner foi o que apresentou maior estabilidade, porém é 
um material com características diferentes do Elite soft. O tempo é um fator importantíssimo na alteração das propriedades dos materiais, tendo interferido em todas as variáveis testadas.

Estudos com o objetivo de aprimorar as características dos materiais para uma aplicação em longo prazo devem ser ainda realizados, visando a viabilidade de uso dos materiais reembasadores. 


\section{REFERÊNCIAS BIBLIOGRÁFICAS ${ }^{1}$}

1. ABELSON, D.C. Denture plaque and denture cleansers. J. Prosthet. Dent., St. Louis, v.45, n.4, p.376-79, Apr. , 1981.

2. ABELSON, D.C. Denture plaque and denture cleansers: review of the literature. Gerodontics, Copenhagen, v.1, n.5, p.202-06, Oct., 1985.

3. AMERICAN DENTAL ASSOCIATION. Council on dental materials and devices. Revised American Dental Association Specification $n^{\circ} 12$ for denture base polymers. J. Am. Dental Assoc., Chicago, v. 90, n.451, 1975.

4. AMERICAN DENTAL ASSOCIATION. Specification No. 17 for denture base temporary relining resins. New York: ANS/ADA, p.116-29, 1983.

5. ALLISON, R.T.; DOUGLAS, W.H. Micro-colonization of the denture-fitting surface by Candida albicans. J. Dent., Guildford, v.1, n.5, Jun., 1973.

6. AMIN, W.M.; FLETCHER, A.M.; RITCHIE, G.M. The nature of the interface between polymethylmethacrylate denture base materials and soft lining materials. J. Dent., Guildford, v.9, n.4, p.336-46, Dec., 1981.

\footnotetext{
1 De acordo com: ASSOCIAÇÃO BRASILEIRA DE NORMAS TÉCNICAS. NBR 6023: informação e
} documentação: referências: elaboração. Rio de Janeiro, 2002. 
7. ANIL, N.; HEKIMOGLU, C.; SAHIN, S. Color stability of heat-polymerized and autopolymerized soft denture liners. J. Prosthet. Dent., St. Louis, v.81, n.4, p.481-84, Apr., 1999.

8. ANUSAVICE, K.J. Acrylic Resins. Phillps'science of Dental Materials. W.B. Saunders Company 10th ed. p. 140-60, 1996.

9. ARIMA, T.; MURATA, H.; HAMADA, T. The effects of cross-linking agents on the sorption and solubility characteristics of denture base resin. J. Oral. Rehabil., Oxford, v.23, n.7, p.476-80, Jul., 1996

10. AYDIN, A.K.; TERZIOGLU, H.; AKINAY, A.E.; ULUBAYRAM, K.; HASIRCI, N. Bond strength and failure analysis of lining materials to denture resin. Dent. Mater., v.15, n.3, p.211-18, May, 1999.

11. AZEVEDO, A.; MACHADO, A.L.; VERGANI, C.E.; GIAMPAOLO, E.T.; PAVARINA, A.C. Hardness of denture base and hard chair-side reline acrylic resins. J. Appl. Oral Sci., Bauru, v.13, n.3, p.291-5, 2005.

12. AZEVEDO, A.; MACHADO, A.L.; GIAMPAOLO, E.T.; PAVARINA, A.C.; VERGANI, C.E. The Effect of Water Immersion on the Shear Bond Strength Between Chairside Reline and Denture Base Acrylic Resins. J. Prosthodont., USA, v.16, n.4., p.25562, Jul-Aug., 2007. 
13. BASCOM, P.W. Resilient denture base materials. J. Prosthet. Dent., St. Louis, v.16, p.646-49, 1966.

14. BATES, J.F; SMITH, D.C. Evaluation of indirect resilient liners. Evaluation of indirect resilient liners. J. Am. Dent. Assoc., Chicago, v.70, n.2, p.344-53, Feb., 1965.

15. BELL, J.A.; BROCKMAN, S.L.; FEIL, P.; SACKWICK, D.A. The effectiveness of two disinfectants on denture base acrylic resin with an organic load.. J. Prosthet. Dent., St. Louis, v.61, n.5, p.580-83, May., 1989.

16. BOTEGA, D.M.; CARMO FILHO, J.L.; MESQUITA, M.F.; NÓBILO, M.A.A.; HENRIQUES, G.E.P. Influence of toothbrushing on surface roughness of soft dednture liners: na in vitro study. Rev. Pós. Grad., São Paulo, v.11, n.2, p.125-29, 2004.

17. BOUCHER, C.O.; HICKEY, J.C.; ZARB, G.A, eds. Prosthodontic treatment for edentulous pacients. $7^{\text {th }}$ ed. St. Louis: C V Mosby; 1975, p.37-8.

18. BRACE, M.L.; PlUMMER, K.D. Practical denture disinfection. J. Prosthet. Dent., St. Louis, v.70, n.6, p.538-40, Dec., 1993.

19. BRADEN, M.; WRIGHT, P.S. Water absorption and water solubility of soft lining materials for acrylic dentures. J. Dent. Res., Copenhagen, v.62, n.6, p.764-68, Jun., 1983. 
20. BROGNIEZ, V.; GRIMONSTER, J.; HONOREZ, P.; GUILLAUME, J.; CATALAN, A.; CONSTENLA, A. Corrosion on dental acrylic resin by alkaline peroxide used for cleaning. Les Cahiers Prothese, v.68, p.42, Dec., 1989.

21. BUDTZ-JORGENSEN, E. The significance of Candida albicans in denture stomatitis. Scand. J. Dent. Res., Copenhagen, v.82, n.2, p.151, 1974.

22. BUDTZ-JORGERSEN, E. Materials and methods for cleaning dentures. J. Prosthet. Dent., St. Louis, v.42, n.6, p.619-23, Dec., 1979.

23. CALDERONE, R.A.; BRAUN, P.C. Adherence and receptor relationships of Candida albicans. Microbiol. Rev., v.55, n.1, p.1-20, Mar., 1991.

24. CANAY, S.; HERSEK, N.; TULUNOGLU, I.; UZUN, G. Evaluation of colour and hardness changes of soft lining materials in food colorant solutions. J. Oral Rehabil., Oxford, v.26, n.10, p.821-29, Oct., 1999.

25. CAUSTON, B.E. Denture base polymers and liners. In O'Brian WJ, editor. Dental materials and their selection. $2^{\text {nd }}$ ed. Chicago: Quintessence; 1997. p. 90-2.

26. CHAU, V.B.; SAUNDERS, T.R.; PIMSLER, M.; ELFRING, D.R. In-depth disinfection of acrylic resins. J. Prosthet. Dent., St. Louis, v.74,n.3, p.309-13, Sep., 1995. 
27. CRAIG, R.G., GIBBOnS, P. Properties of resilient denture liners. J. Am. Dent. Assoc., Chicago, v.63, p.65-72, Sep., 1961.

28. CUTLER, J.E. Putative virulence factors of Candida albicans. Annu. Rev. Microbiol., v.45, p.187-18, 1991.

29. DAVENPORT, J.C.; WILSON, H.J.; SPENCE, D. The compatibility of soft lining materials and denture cleansers. Br. Dent. J., London, v.161, n.1, p.13-7, 1986.

30. DAVENPORT, J.C.; WILSON, H.J.; BASKER, R.M. The compability of tissue conditioners with denture cleaners and chlorhexidine. J. Dent., v.6, n.3, p.239-46, Sep., 1978.

31. DILLS, S.S.; OLSHAN, A.M.; GOLDNER, S.; BROGDON, C. Comparison of the antimicrobial capability of an abrasive paste and chemical-soak denture cleansers. $\mathbf{J}$. Prosthet. Dent., St. Louis, v.60, n.4., p467-70, Oct., 1988.

32. DOOTZ, E.R.; KORAN, A.; CRAIG, R.G. Physical property comparison of 11 soft lining materials as a function of accelerated aging. J. Prosthet. Dent., St Louis, v.69, n.1, p.114-19, Jan.,1993.

33. DOUGLAS, W.H. Resilient soft materials in dentistry. North. West. Dent., v.58, n.3, p.116, May-Jun, 1979. 
34. EICK, J.D.; CRAIG, R.G.; PEYTON, F.A. Properties of resilient denture liners in simulated mouth conditions. J. Prosthet. Dent., St. Louis, v.12, p.1043-52, 1962.

35. EL-HADARY, A.; DRUMMOND, J.L. Comparative study of water sorption, solubility, and tensile bond strength of two soft lining materials. J. Prosthet. Dent., St. Louis, v.83, n.3, p.356-61, Mar., 2000.

36. EMMER, T.J. JR; EMMER, T.J. SR; VAIDYNATHAN, J.; VAIDYNATHAN, T.K. Bond strength of permanent soft denture liners bonded to the denture base. J. Prosthet. Dent., St. Louis, v.74, n.6, p.595-601, Dec., 1995.

37. FEITOSA, M.L.; VASCONCELOS L.M.; RODRIGUES GARCIA, R.C., MATHEUS RODRIGUES; CURY, A.A.D.B. Efeito dos limpadores químicos de próteses sobre o peso de reembasador resiliente temporário. RPG, São Paulo, v.10, n.3, p.199-203, Jul.-set. 2003

38. GARCIA, R.C.M.; LEON, B.L.; OLIVEIRA, V.M.B.; DEL BEL CURY, A.A. Effect of a denture cleanser on weight, surface roughness, and tensile bond strength of two resilient denture liners. J. Prosthet. Dent., St Louis, v.89, n.5, p.489-94, May., 2003.

39. GOLDSTEIN, G.R.; SCHMITT, G.W. Repeatability of a specially designed intraoral colorimeter. J. Prosthet. Dent., St. Louis, v.69, n.6, p.616, Jun., 1993.

40. GOLL, G.; SMITH, D.E.; PLEIN, J.B. The effect of denture cleansers on temporary soft liners. J. Prosthet. Dent., St. Louis, v.50, n.4, p.466-72, Oct., 1983. 
41. GORNITSKY, M.; PARADIS, I.; LANDAVERDE, G.; MALO, A.; VELLY; A.M. A Clinical and Microbiological Evaluation of Denture Cleansers for Geriatric Patients in LongTerm Care Institutions. J. Can. Den. Assoc., Canadá, v.68, n.1, p.39-45, Jan., 2002.

42. GRAHAN, B.S.; JONES, D.W.; BURKE, J.; THOMPSON, J.P. In vivo fungal presence and growth on two resilient denture liners. J. Prosthet. Dent., St. Louis, v.65, n.4, p.528-32, Apr., 1991.

43. HARGREAVES, A.S. The prevalence of fractured dentures. A survey. Br. Dent. J., London, v.126, n.10, p.451-55, May., 1969.

44. HARRISON, A.; BASKER, R.M.; SMITH, I.S. The compatibility of temporary soft materials with immersion denture cleansers. Int. J. Prosthodont., Lombard, v.2, n.3, p.254, May-Jun., 1989.

45. HAYAKAWA, I.; AKIBA, N.; KEH, E.; KASUGA, Y. Physical properties of a new denture lining material containing a fluoroalkyl methacrylate polymer. J. Prosthet. Dent., St. Louis, v.96, n.1, p.53-8, Jul., 2006

46. HAYWOOD, J.; BASKER, R.M.; WATSON, C.J.; WOOD, D.J. A comparison of three hard chairside denture reline materials. Part I. Clinical evaluation. Eur. J. Prosth. Restor. Dent., Larkfield, v.11, n.4, p.157-63, Dec., 2003. 
47. HEKIMOGLU, C.; ANIL, N. Sorption and solubility of soft denture liners after accelerated aging. Am. J. Dent., USA, v.12, n.1, p.44-6, Feb.,1999.

48. JAGGER, D.C.; HARRISON, A. Denture cleansing - the best approach. Br. Dent. J., London, v.178, n.11, p.413-7, Jun., 1995.

49. JIN, C.; NIKAWA, H.; MAKIHIRA, S.; HAMADA, T.; FURUKAWA, M.; MURATA, H. Changes in surface rougness and colour stability of soft denture lining materials caused by denture cleansers. J. Oral Rehabil., Oxford, v.30, n.2, p.125-30, Feb., 2003.

50. JOHNSON, W.M. \& KAO, E.C. Assessment of appearance match by visual observation and clinical colorimetry. J. Dent. Res., Washington, v.68, n.5, p.819, May., 1989.

51. KAZANJI, M.N.M.; WATKINSON, A.C. Soft lining materials; their absorption of, and solubility in, artificial saliva. Br. Dent. J., London, v.165, n.3, p.91-4, Aug., 1988.

52. KAWANO, F.; DOOTZ, E.R.; KORAN, A. 3rd, CRAIG, R.G. Comparison of bond strength of six soft denture liners to denture base resin. J. Prosthet. Dent., St Louis, v.68, n.2, p.368-71, Aug., 1992.

53. KAWANO, F.; DOOTZ, E.R.; KORAN, A. 3rd; CRAIG, R.G. Sorption and solubility of 12 soft denture liners. J. Prosthet. Dent., St. Louis, v.72, n.4, p.393-98, Oct., 1994. 
54. KIAT-AMNUAY, S.; GETTLEMAN, L.; MEKAYARAJJANANONTH, T.; KHAN, Z.; GOLDSMITH, L.J. The influence of water storage on durometer hardness of 5 soft denture liners over time. J. Prosthodont., USA, v.14, n.1, p.19-24, Mar., 2005.

55. KULAK, Y.; ARIKAN, A.; ALBAK, S.; OKAR, I.; KAZAZOGLU, E. Scanning electron microscopic examination of different cleansers: surface contaminant removal from dentures. J. Oral Rehabil., Oxford, v.24, n.3, p.1209-15, Mar., 1997.

56. LAMIE, G.A.; STORER, R. A preliminary report on resilient denture plastics. J. Prosthet. Dent., St. Louis, v.8, p.411-24, 1958.

57. LEON, B.L.; DEL BEL CURY, A.A.; RODRIGUES GARCIA, R.C. Water sorption, solubility, and tensile bond strength of resilient denture lining materials polymerized by different methods after thermal cycling. J. Prosthet. Dent., St. Louis, v.93, n.3, Mar., 2005.

58. LOUKA, A.M.; GESSER, H.D.; KASLOFF, Z. A laboratory evaluation of effect of two surface-wetting treatments on soft denture liners. J. Dent. Res., USA, v.56, n.8, p.953-59, Aug., 1977.

59. LOVE, W.D.; GOSKA, F.A.; MIXSON, R.J. The etiology of mucosal inflammation associated with dentures. J. Prosthet. Dent., St. Louis, v.18,n.6, p.515-27, Dec., 1967. 
60. MA, S.; JOHNSON, G.H.; GORDON, G.E. Effects of chemical disinfectants on the surface characteristics and color of denture resins. J. Prosthet. Dent., St. Louis, v.77, n.2, p.197-204, Feb., 1997.

61. MACHADO, A.L.; BREEDING, L.C.; PUCKETT, A.D. Effect of microwave disinfection on the hardness and adhesion of two resilient liners. J. Prosthet. Dent., St. Louis, v.94, n.2, p.183-89, Aug., 2005.

62. MACK, P.J. Denture soft lining materials: clinical indications. Austral. Dent. J., Australia, v.34, n.5, p.454-58, Oct., 1989.

63. MAKILA, E.; HONKA, O. Clinical study of a heat-cured silicone soft lining material. J. Oral Rehabil., Oxford, v.6, n.2, p.199-204, Apr., 1979.

64. MATTHEWS, E. Soft resin lining for dentures. Br. Dent. J., London, v.78, p.140, 1945.

65. MATSUMURA, H.; TANOUE, N.; KAWASAKI, K.; ATSUTA M. Clinical evaluation of a chemically cured hard denture relining material. J. Oral Rehabil., Oxford, v.28, n.7, p.640-44, Jul., 2001.

66. McCABE, J.F. Soft lining materials: composition and structure. J. Oral Rehabil., Oxford, v.3, n.3, p.273-78, Jul., 1976. 
67. MINAGI, S.; TSUNODA, T.; YOSHIDA, K.; TSURU, H. Objective testing of the efficiency of denture cleansing agents. J. Prosthet. Dent., St. Louis, v.58, n.5, p.395-98, Nov., 1987

68. MOORE, T.C.; SMITH, D.E.; KENNY, G.E. Sanitization of dentures by several denture hygiene methods. J. Prosthet. Dent., St. Louis, v.52, n.2, p.158-53, Aug. 1984.

69. MURATA, H.; HAMADA, T.; HARSHINI, T.K.; NIKAWA, H. Effect of addition of ethyl alcohol on gelation and viscoelasticity of tissue conditioners. J. Oral Rehabil.., Oxford, v.28, n.1, p.48-54, Jan., 2001a.

70. MURATA, H.; KAWAMURA, M.; HAMADA, T.; SALEH, S.; KRESNOADI, U.; TOKI, K. Dimensional stability and weight changes of tissue conditioners. J. Oral Rehabil., Oxford, v.28, n.10, p.918-23, Oct., 2001b.

71. NIKAWA, H.; HAMADA, T.; YAMMAMOTO, T. Denture plaque - past and recent concerns. J. Dent., Guildford, v.26, n.4, p.299, May., 1998.

72. NIKAWA, H.; HAMADA, T.; YAMASHIRO, H.; KUMAGAI, H. A review of in vitro and in vivo methods to evaluate the efficacy of denture cleansers. Int. J. Prosthodont., Lombard, v.12, n.2, p.153, Mar.Apr., 1999. 
73. NIKAWA H, IWANAGA H, HAMADA T, YUHTA S. Effects of denture cleansers on direct soft dentures lining materials. J. Prosthet. Dent., St. Louis, v.72, n.6, p.657-62., Dec., 1994.

74. NIKAWA, H.; YAMAMOTO, T.; HAMADA,T. Effect of components of resilient denture -lining materials on the growth, acid production and colonization of Candida albicans. J, Oral Rehabil., Oxford, v.22, n.11, p.817-24, Nov., 1995.

75. NIKAWA, H.; IWANAGA, H.; KAMEDA, M.; HAMADA, T. In vitro evaluation of Candida albicans adherence to soft denture-lining materials. J. Prosthet. Dent., St. Louis, v. 68, n.5, p.804-08, Nov., 1992.

76. NIKAWA, H.; JIN, C.; MAKIHIRA, H.; EGUSA, H.; HAMADA, T.; KUMAGAI, H. Biofilm formation of Candida albicans on the surfaces of deteriorated soft denture lining materials caused by denture cleansers in vitro. J. Oral Rehabil., Oxford, v.30, n.3, p.243-50, Mar., 2003.

77. NIKAWA, H.; JIN, C.; HAMADA, T.; MAKIHIRA, H.; KUMAGAI, H.; MURATA, H. Interactions between thermal cycled resilient denture lining materials, salivary and serum pellicles and Candida albicans in vitro: Part II. Effects on fungal colonizatrion. J. Oral Rehabil., Oxford, v.27, n.2, p.124-30, Feb., 2000.

78. NIMEROFF, L. Colorimetry. DC: Nat. Bureau Stand. Monograph no 104. Washington, 47, 1968. 
79. ODMAN P.A. The effectiveness of an enzyme-containing denture cleanser. Quintessence Int., v.23, n.3, p.187-90, Mar.,1992.

80. OLIVEIRA, L.V.; MESQUITA, M.F.; HENRIQUES, G.E.P.; CONSANI, R.L.X. The Effect of Brushing on Surface Roughness of Denture Lining Materials. J. Prosthodont., USA, v.16, n.3, p.179-84, May-Jun., 2007.

81. PARANHOS, H.F.O.; PARDINI, L.C.; PANZERI, H. Hábitos de higienização de portadores de prótese total. Ver. Paul. Odontol., São Paulo, v.12, p.11-21, 1991.

82. PARKER, S.; RIGGS, P.D.; BRADEN, M.; KALACHANDRA, S.; TAYLOR, D.F. Water uptake of soft lining materials from osmotic solutions. J. Dent., Oxford, v.25, n.3-4, p.297-304, May- Jul., 1997.

83. PARKER, S.; BRADEN, M. Water absorption of methacrylate soft lining materials. Biomaterials, v.10, n.2, p.91-5, Mar., 1989.

84. PARR, G.R.; RUEGGEBERG, F.A. In vitro hardness, water sorption, and resin solubility of laboratory-processed and autopolymerized long-term resilient denture liners over one year of water storage. J. Prosthet. Dent., St. Louis, v.88, n.2, p.139-44, Aug., 2002.

85. PAVAN, S.; ARIOLI FILHO, J.N.; DOS SANTOS, P.H.; NOGUEIRA, S.S.; BATISTA, A.U. Effect of disinfection treatments on the hardness of soft denture liner materials. $\mathbf{J}$. Prosthodont., USA, v.16, n.2, p.101-06, Mar-Apr., 2007. 
86. PESUN, I.J.; VILLAR, A.; HODGES, J.S.; DELONG, R.; LAI, J.H.; SCHNEIDER, D. Development of a nondestructive compliance test for resilient denture liners. J. Prosthodont., USA, v.10, n.2, p.91-6, Jun., 2001.

87. PHILLIPS, R.W. Materiais dentários de Skinner. $8^{\mathrm{a}}$. ed. Rio de Janeiro: Interamericana, 1984. Cap. 12, p.126-138.

88. POLYZOIS, G.L. Denture cleansing habits. A survey. Aust Dent J., v.28, n.3, p.171-73, Jun., 1983.

89. POLYZOIS, G.L.; YANNIKAKIS, S.A.; ZISSIS, A.J.; DEMETRIOU, P.P. Color changes of denture base materials after disinfectation and sterilization immersion. Int. J. Prosthodont., USA, v.10, n.11, p.83-9, Jan-Fev., 1997.

90. POLYZOIS, G.L.; FRANGOU, M.J. Influence of curing method, sealer, and water storage on the hardness of a soft lining material over time. J. Prosthodont., USA, v.10, n.11, p.42-5, Mar., 2001.

91. POPPER, F. Undercuts and resilient denture liners. J. Dent. Assoc. South. Afr., v.19, p.77-81, 1945.

92. POWERS, J.M.; BARAKAT, M.M.; OGURA, H. Color and optical properties of posterior composites under accelerated aging. Dent. Mater. J., v.4, n.1, p.62-7, Jun., 1985. 
93. POWERS, J.M.; DENNISON, J.B.; KORAN, A. Color stability of restorative resins under accelerated aging. J. Dent. Res., USA, v.57, n.11-12, p.964-70, Nov-Dec., 1978.

94. POWERS, J.M.; FAN, P.L.; RAPTIS, C.N. Color stability of new composite restorative materials under accelerated aging. J. Dent. Res., v.59, n.12, p.2071-4, Dec., 1980.

95. PURNAVEJA, S.; FLETCHER, A.M.; RITCHIE, G.M.; AMIN, W.M.; MORADIANS, S.; DODD, A.W. Compatibility of denture cleansers with some new self curing denture base materials. Biomaterials., v.3, n.4, p.251-2, Oct., 1982.

96. QUDAH, S.; HARRISON, A.; HUGGETT, R. Soft lining materials in prosthetic dentistry: a review. Int. J. Prosthodont., Lombard, v.3, n.3, p.477-83, Sep-Oct., 1990.

97. QUDAH, S.; HUGGETT, R.; HARRISON, D. The effect of thermocycling on the hardness of soft lining materials. Quintessence Int., Berlim, v.22, n.7, p.575-80, Jul., 1991.

98. RAHAL, S.J.; MESQUITA, M.F. Influência dos polimentos mecânico e químico sobre propriedades de resinas acrílicas ativadas termicamente. Piracicaba, 2001. Dissertação (mestrado em Clínica Odontológica)- Faculdade de Odontologia de Piracicaba, Universidade Estadual de Campinas. 161p.

99. REIS， J.M.S.N.; VERGANI， C.E.; PAVARINA， A.C.; GIAMPAOLO, E.T.; MACHADO, A.L. Effect of relining, water storage and cyclic loading on the flexural strength of a denture base acrylic resin. J. Dent., Guildford, v.3 4, n.7, p.420-26, Aug., 2006. 
100. RUDD, R.W.; SENIA, E.S.; MCCLESKEY, F.K.; ADAM, E.D.JR. Sterilization of complete dentures with sodium hypochlorite. J. Prosthet. Dent., St. Louis, v.51, n.3, p.31821, Mar., 1984.

101. RUSSELL, E.A. Jr. Management of mucoepidermoid carcinoma of the palate. Report of a case. Oral Surg. Oral Med. Oral Pathol., v.41, n.4, p.436-40, Apr., 1976.

102. SARAÇ, D.; SARAÇ, S.; KURT, M.; YÜZBASIOGLU, E. The effectiveness of denture cleansers on soft denture liners colored by food colorant solutions. J. Prosthodont., USA, v.16, n.3, p.185-91, May-Jun., 2007.

103. SCHWARTZ-AROD, D.; CHAUSHU, G. Placement of implants into fresh extraction sites: 4 to 7 years retrospective evaluation of 95 immediate implants. J. Periodontol., Massachusetts, v.68, n.11, p.1110-6, Nov., 1977.

104. SESMA, N.; TAKADA, K.S.; LAGANÁ, D.C.; JAEGER, R.G.; AZAMBUJA, JR. N. Eficiência de métodos caseiros de higienização e limpeza de próteses parciais removíveis. Rev. Assoc. Paul. Cir. Dent., São Paulo, v.53, n.6, p.463-67, 1999.

105. SHEN, C.; JAVID, J.S.; COLAIZZI, I.A. The effect of glutaraldehyde base disinfectants on denture base resins. J. Prosthet. Dent., St. Louis, v.61, n.5, p.583-89, May., 1989. 
106. SINOBAD, D.; MURPHY, W.M.; HUGGET, R.; BROOKS, S. Bond strength and rupture properties of some soft denture liners. J. Oral Rehabil., Oxford, v.19, n.2, p.151-60, Mar., 1992.

107. STORER, R. Resilient denture base materials. Part 2. Br. Dent. J., London, v.113, p.231-38, 1962.

108. TAN, H.; WOO, A.; KIM, S.; LAMOUREUX, M.; GRACE, M. Effect of denture cleansers, surface finishing, and temperature on molloplast b resilient liner color, hardness, and texture. J. Prosthodont., USA, v.9, n.3, p.148-55, Sep., 2000.

109. TARBET, W.J.; AXELROD, S.; MINKOFF, S.; FRATARCANGELO, P,A. Denture cleansing: a comparison of two methods. J. Prosthet. Dent., St Louis, v.51, n.3, p.322-25, Mar., 1984.

110. TYLMAN, S.D. The use of elastic and resilient synthetic resins and their copolymer in oral, dental and facial prostheses. Dent. Digest., v.49, p.167-96, 1943.

111. VILLAR, A.; PESUN, I.J; BROSKY, M.E.; FINES, C.; HODGES, J.S.; DELONG, R. Clinical evaluation of a new resilient denture liner. Part 1: Compliance and color evaluation. J. Prosthodont., USA, v.12, n.2, p.82-9, Jun., 2003. 
112. WAGNER, W.C.; KAWANO, F.; DOOTZ, E.R.; KORAN, AIII. Dynamic viscoelastic properties of processed soft denture liners: part II - Effect of aging. J. Prosthet. Dent., v.74, n.3, p.299-304, Sep., 1995.

113. WATERS, M.G.; JAGGER, R.G.; WINTER, R.W. Water absorption of (RTV) silicone denture soft lining material. J. Dent., Guildford, v.24, n.1-2, p.105-8, Jan-Mar., 1996.

114. WILSON, H. J. Materiais dentários e suas aplicações clínicas. São Paulo: Santos, 1989. cap. 9, p. 101-9.

115. WRIGHT, P.S. Soft lining materials: their status and prospects. J. Dent., Guildford, v.4, n.6, p.247-56, Nov., 1976.

116. WRIGHT, P.S. Characterization of the adhesion of soft lining materials to poli(methyl methacrylate). J. Dent. Res., Washington, v.61, n.8, p.1002-05, Aug., 1982.

117. YATABE, M.; YASUDA, N.; AI, M.; OKABE, Y. Unpolymerized layer on autopolymerizing hard reline materials. Int. J. Prosthodont., Lombard, v.12, n.2, p.129, MarApr., 1999.

118. YILMAZ H.; AYDIN, C.; BAL BT., ÕZÇELIT B. Effects of disinfectants on resilient denture-lining materials contaminated with Staphilococcus aureaus, Streptococcus sobrinus and Candida albicans. Quintessence Int., Berlim, v.36, n.5, p.373-81. May., 2005. 
119. YOELI, Z.; MILLER, V.; ZELTSER, C. Consistency and softness of soft liners. J. Prosthet. Dent., St. Louis, v.75, n.4, p.412-18, Apr., 1996.

120. ZISSIS, A.J.; POLYZOIS, G.L.; YANNIKAKIS, A.S.; HARRISON, A. Roughness of denture materials: a comparative study. Int. J. Prosthodont., Lombard, v.13, n.2, p.136-40, Mar-Apr., 2000. 


\section{APÊNDICES}

Apêndice A - Testes estatísticos para os dados do ensaio de sorção.

Tabela A1 - Teste de aderência à curva normal - valores originais.

\begin{tabular}{llllllll}
\hline A. Freqüências por intervalos de classe: \\
\hline Intervalos de classe & $\mathrm{M}-3 \mathrm{~s}$ & $\mathrm{M}-2 \mathrm{~s}$ & $\mathrm{M}-1 \mathrm{~s}$ & $\mathrm{Med}$ & $\mathrm{M}+1 \mathrm{~s}$ & $\mathrm{M}+2 \mathrm{~s}$ & $\mathrm{M}+3 \mathrm{~s}$ \\
Curva normal & 0.44 & 5.40 & 24.20 & 39.89 & 24.20 & 5.40 & 0.44 \\
Curva experimental & 0.00 & 0.00 & 18.33 & 68.33 & 10.00 & 1.67 & 1.67 \\
\hline B. Cálculo do Qui quadrado & 4 & \multicolumn{5}{c}{ Interpretação } \\
\hline Graus de liberdade & 4 & \multicolumn{5}{c}{ A distribuição amostral testada é } \\
Valor do Qui quadrado & 38.02 & & \multicolumn{3}{c}{ não normal } \\
Probabilidade de Ho & $0.0000 \%$ & & & & \\
\hline
\end{tabular}


Apêndice B - Testes estatísticos para os dados do ensaio de solubilidade.

Tabela B1 - Teste de aderência à curva normal - valores originais.

\begin{tabular}{llllllll}
\hline \multicolumn{1}{l}{ A. Freqüências por intervalos de classe: } \\
\hline Intervalos de classe & $\mathrm{M}-3 \mathrm{~s}$ & $\mathrm{M}-2 \mathrm{~s}$ & $\mathrm{M}-1 \mathrm{~s}$ & $\mathrm{Med}$. & $\mathrm{M}+1 \mathrm{~s}$ & $\mathrm{M}+2 \mathrm{~s}$ & $\mathrm{M}+3 \mathrm{~s}$ \\
Curva normal & 0.44 & 5.40 & 24.20 & 39.89 & 24.20 & 5.40 & 0.44 \\
Curva experimental & 0.00 & 6.67 & 26.67 & 41.67 & 16.67 & 6.67 & 1.67 \\
\hline B. Cálculo do Qui quadrado: & \multicolumn{5}{c}{ Interpretação } \\
\hline $\begin{array}{l}\text { Graus de liberdade } \\
\text { Valor do Qui quadrado }\end{array}$ & 4.27 & A distribuição amostral testada \\
Probabilidade de Ho & $51.3700 \%$ & \multicolumn{5}{c}{ é normal } \\
\hline
\end{tabular}


Apêndice C - Testes estatísticos para os dados do ensaio de cor.

Tabela C1 - Teste de aderência à curva normal - valores originais.

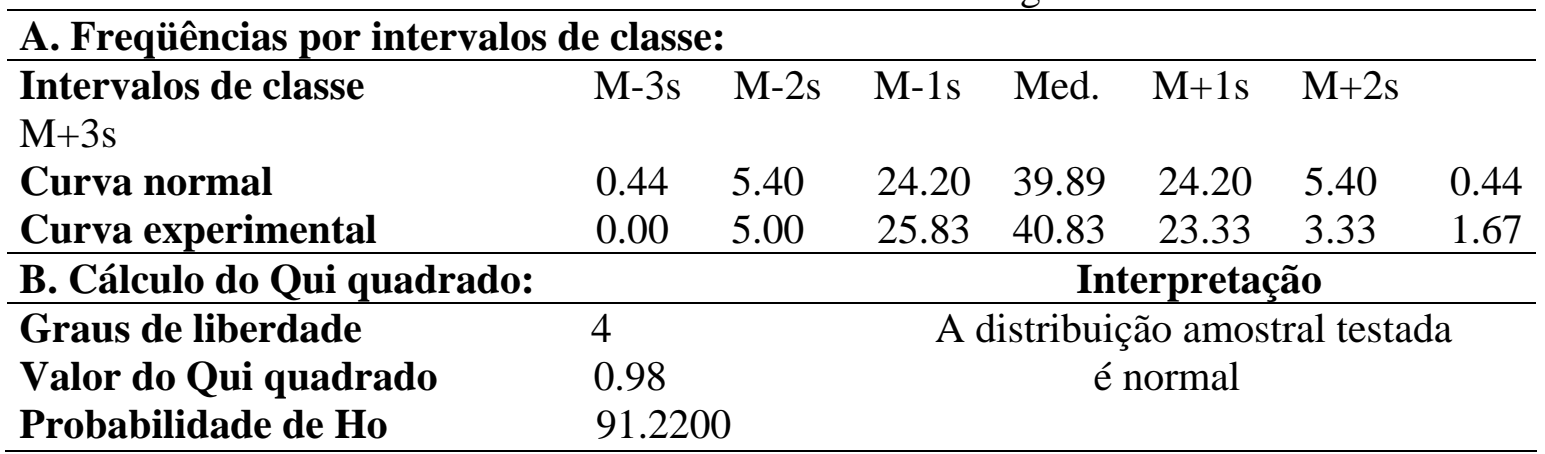


Apêndice D - Testes estatísticos para os dados do ensaio de dureza.

Tabela D1 - Teste de aderência à curva normal dos dados do ensaio de dureza do material Kooliner - valores originais.

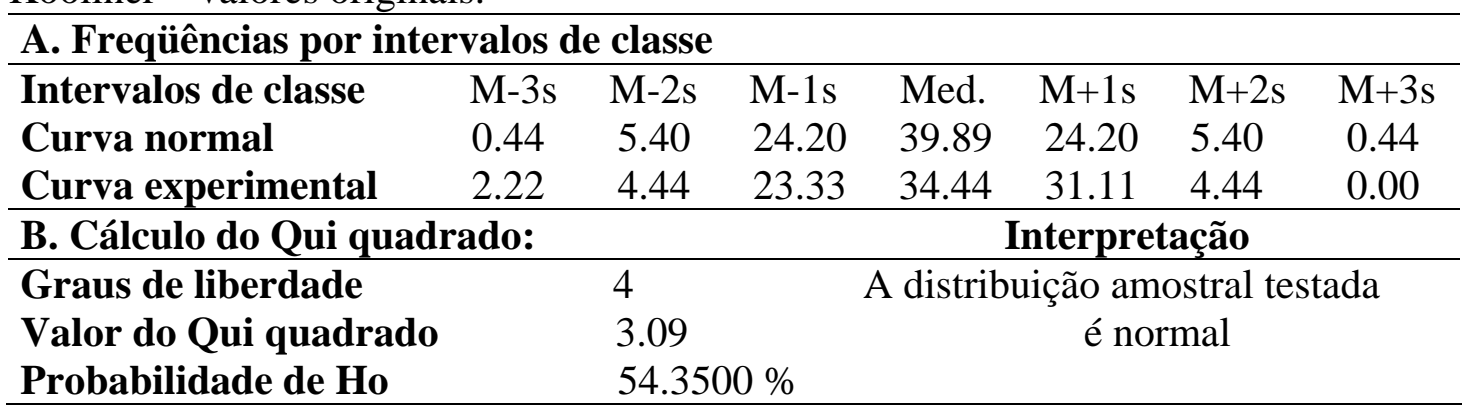

Tabela D2 - Teste de aderência à curva normal dos dados do ensaio de dureza do material Elite soft - valores originais.

\begin{tabular}{lllllllr}
\hline \multicolumn{1}{l}{ A. Freqüências por intervalos de classe: } & & & & \\
\hline Intervalos de classe & $\mathrm{M}-3 \mathrm{~s}$ & $\mathrm{M}-2 \mathrm{~s}$ & $\mathrm{M}-1 \mathrm{~s}$ & $\mathrm{Med}$ & $\mathrm{M}+1 \mathrm{~s}$ & $\mathrm{M}+2 \mathrm{~s}$ & $\mathrm{M}+3 \mathrm{~s}$ \\
Curva normal & 0.44 & 5.40 & 24.20 & 39.89 & 24.20 & 5.40 & 0.44 \\
Curva experimental & 0.00 & 6.67 & 18.33 & 45.00 & 23.33 & 6.67 & 0.00 \\
\hline B. Cálculo do Qui quadrado: & & \multicolumn{4}{c}{ Interpretação } \\
\hline Graus de liberdade & 4 & & A distribuição amostral testada \\
Valor do Qui quadrado & 2.70 & & \multicolumn{3}{c}{ é normal } \\
Probabilidade de Ho & $60.8800 \%$ & & & & \\
\end{tabular}


Malheiros-Segundo, A.L. Solução efervescente para higiene de próteses totais: influência na sorção de água, solubilidade, dureza e na alteração de cor de reembasadores. 2007. $101 \mathrm{f}$. Dissertação (Mestrado em Reabilitação Oral) - Faculdade de Odontologia de Ribeirão Preto, Universidade de São Paulo, Ribeirão Preto.

\section{ERRATA}

Folha 37 - Substituir figura 7 por:

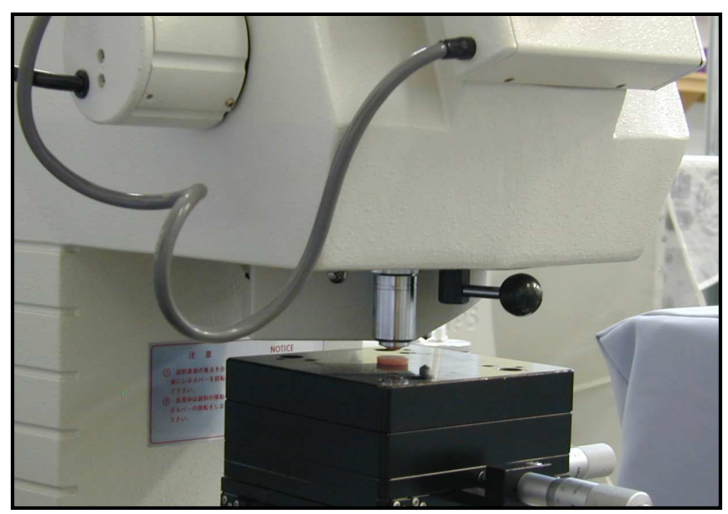

Folha 42 - Substituir a tabela 4 para:

Tabela 4 - Sorção sofrida pelos corpos-de-prova de Kooliner e Elite Soft após 120 dias de imersão nos grupos controle e experimental.

\begin{tabular}{|c|c|c|c|c|}
\hline \multirow[t]{2}{*}{$\mathbf{N}$} & \multicolumn{2}{|c|}{ Kooliner } & \multicolumn{2}{|c|}{ Elite Soft } \\
\hline & T1 & $\mathbf{T} 2$ & T1 & $\mathbf{T} 2$ \\
\hline 1 & 1,21 & 1,21 & 0,40 & 0,40 \\
\hline 2 & 1,62 & 2,02 & 0,20 & 1,01 \\
\hline 3 & 1,62 & 1,62 & 0,40 & 0,40 \\
\hline 4 & 1,42 & 1,21 & 0,20 & 0,61 \\
\hline 5 & 1,62 & 1,21 & 0,20 & 0,61 \\
\hline 6 & 1,42 & 2,02 & 0,40 & 0,61 \\
\hline 7 & 1,62 & 1,62 & 0,40 & 0,61 \\
\hline 8 & 1,42 & 3,24 & 0,20 & 0,40 \\
\hline 9 & 1,42 & 1,62 & 0,40 & 0,40 \\
\hline 10 & 1,42 & 1,62 & 0,20 & 0,40 \\
\hline 11 & 1,21 & 1,62 & 0,20 & 0,61 \\
\hline 12 & 1,42 & 1,42 & 0,40 & 0,40 \\
\hline 13 & 1,21 & 1,42 & 0,20 & 0,61 \\
\hline 14 & 1,42 & 1,21 & 0,40 & 0,40 \\
\hline 15 & 1,42 & 1,42 & 0,20 & 0,20 \\
\hline Médias & 1,43 & 1,63 & 0,29 & 0,51 \\
\hline DP & 0,13 & $\mathbf{0 , 5 0}$ & 0,10 & 0,18 \\
\hline
\end{tabular}

Folha 65, linha 13 - Inserir a palavra "não" entre as palavras "resultados" e "estão". Folha 75, linha 16 - Substituir a primeira frase do sexto parágrafo por:

"O perborato de sódio não influenciou de forma significativa, as propriedades de sorção, cor e dureza do Kooliner. Para o Elite soft, somente a cor não sofreu alteração." 